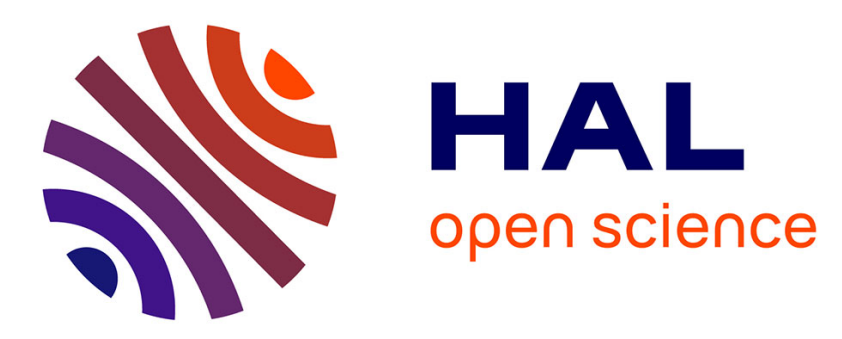

\title{
Structure-activity relationship study of hypoxia-activated prodrugs for proteoglycan-targeted chemotherapy in chondrosarcoma
}

Donia Ghedira, Aurélien Voissiere, Caroline Peyrode, Jamil Kraiem, Yvain Gerard, Elise Maubert, Magali Vivier, Elisabeth Miot-Noirault, Jean-Michel J.-M. Chezal, Farhat Farhat, et al.

\section{To cite this version:}

Donia Ghedira, Aurélien Voissiere, Caroline Peyrode, Jamil Kraiem, Yvain Gerard, et al.. Structureactivity relationship study of hypoxia-activated prodrugs for proteoglycan-targeted chemotherapy in chondrosarcoma. European Journal of Medicinal Chemistry, 2018, 158, pp.51 - 67. 10.1016/j.ejmech.2018.08.060 . hal-01926337

\section{HAL Id: hal-01926337 \\ https://hal.science/hal-01926337}

Submitted on 19 Nov 2021

HAL is a multi-disciplinary open access archive for the deposit and dissemination of scientific research documents, whether they are published or not. The documents may come from teaching and research institutions in France or abroad, or from public or private research centers.
L'archive ouverte pluridisciplinaire HAL, est destinée au dépôt et à la diffusion de documents scientifiques de niveau recherche, publiés ou non, émanant des établissements d'enseignement et de recherche français ou étrangers, des laboratoires publics ou privés. 


\section{Structure-activity relationship study of Hypoxia-Activated Prodrugs for Proteoglycan-targeted chemotherapy in chondrosarcoma}

Authors: Donia Ghedira ${ }^{a, b}$, Aurélien Voissière ${ }^{a}$, Caroline Peyrode ${ }^{a}$, Jamil Kraiem ${ }^{b}, Y_{\text {Vain }}$ Gerard $^{a}$, Elise Maubert ${ }^{\mathrm{a}}$, Magali Viviera ${ }^{\mathrm{a}}$, Elisabeth Miot-Noirault ${ }^{\mathrm{a}}$, Jean-Michel Chezal ${ }^{\mathrm{a}}$, Farhat Farhat $^{\mathrm{b}}$, Valérie Weber ${ }^{\mathrm{a}, *}$

\section{Affiliations:}

a Université Clermont Auvergne, INSERM, U1240 Imagerie Moléculaire et Stratégies Théranostiques, F-63000 Clermont-Ferrand, France

b Laboratoire de Développement Chimique, Galénique et Pharmacologique des Médicaments, Faculté de Pharmacie de Monastir, Université de Monastir, 5000 Monastir, Tunisia

*Corresponding author: Valérie Weber - Phone : 00334731508 21, Fax : 0033473150801 , e-mail: valerie.weber@uca.fr

Keywords: Hypoxia-activated prodrug, Quaternary ammonium, Chondrosarcoma, Proteoglycan, 


\section{Abstract}

Due to an abundant chondrogenic, poorly vascularized and particularly hypoxic extracellular matrix, chondrosarcoma, a malignant cartilaginous tumour, is chemo- and radioresistant. Surgical resection with wide margins remains the mainstay of treatment. To address the lack of therapy, our strategy aims to increase anticancer drugs targeting and delivery in the tumour, by leveraging specific chondrosarcoma hallmarks: an extensive cartilaginous extracellular matrix, namely the high negative fixed charge density and severe chronic hypoxia. A dual targeted therapy for chondrosarcoma was investigated by conjugation of a hypoxiaactivated prodrug (HAP) to quaternary ammonium (QA) functions which exhibit a high affinity for polyanionic sites of proteoglycans (PGs), the major components of the chondrosarcoma extracellular matrix. Based on preclinical results, an imidazole prodrug, ICF05016, was identified and provided the basis for a lead optimization study. A series of 27 QA-phosphoramide mustard conjugates, differing by the type of QA function and the length of the alkyl linker, was yielded by a common multi-step sequence involving phosphorylation of a key 2-nitroimidazole alcohol. Then, a screening was realized by surface plasmon resonance technology to assess biomolecular interactions between QA derivatives and aggrecan, the most abundant PG in chondrosarcoma. Results revealed that affinity depends more on the type of QA function, than on the linker length. Moreover, the presence of a benzyle group enhanced affinity to aggrecan. Twelve compounds were shortlisted and evaluated for antiproliferative activity (i.e., growth inhibiting concentration 50), under normoxic and hypoxic conditions using the human extraskeletal myeloid chondrosarcoma cell line (HEMC-SS). For all prodrugs, hypoxic selectivity was maintained and even increased, compared with the lead. From this study, compound 31f emerged as the most effective PG-targeted HAPs with a dissociation constant of $2.10 \mathrm{mM}$ in the SPR experiment, a hypoxia cytotoxicity ratio of 24 and an efficient reductive cleavage under chemical and enzymatic conditions. 


\section{Introduction}

Chondrosarcomas represent a heterogeneous group of rare and slowly-growing types of bone sarcomas sharing common features such as their mesenchymal origin and the presence of a cartilaginous extracellular matrix. Among all primary malignant bone sarcomas, chondrosarcoma is the second most common after osteosarcoma, but the first in adults. ${ }^{1}$ To date, the therapeutic tools available for the management of the disease are very few. ${ }^{2,3}$ Surgical resection with wide margins in surrounding non-tumour tissue is still considered the mainstay of treatement and the only recommended therapy for non-metastatic chondrosarcoma, all grades and subtypes included. Well-conducted surgery has been reported to correlate with better control of the disease, i.e. lower frequency of local recurrence, and improved overall survival. Nevertheless, wide margin excision is not always possible (in some anatomic locations) or could entail a significant morbidity for the patient. ${ }^{2,4-6}$ Also, the current clinical challenge is to prevent recurrences and to offer new treatment options for patients with inoperable primary, recurrent disease, and/or metastases. As regards to radiotherapy and conventional chemotherapy, chondrosarcoma is known as a resistant lesion ${ }^{7-9}$ due to tumour's specific hallmarks. Like hyaline cartilage, tumour tissue is marked by a dense and extensive extracellular matrix with poor blood and lymph vascularity, on which a low percentage of dividing cells is embedded. The extracellular matrix creates a physical semi-permeable barrier, which prevents cytotoxic agents reaching their target, i.e tumour chondrocytes, while reduced blood circulation creates severe chronic hypoxia. ${ }^{10}$ The latter is also well known to be associated with radio- and chemo-resistance in cancer. ${ }^{11-13}$

Given the lack of significant improvement in terms of patient survival over the past three decades, new therapeutic targets, such as isocitrate dehydrogenase, m-TOR and Hedgehog pathway inhibitors have been investigated and are currently used in rational drug design for the development of new targeted therapies ${ }^{14}$. The challenges of translating these drugs into clinical use unfortunately failed and no substance has been approved so far ${ }^{15,16}$.

In clinic, commonly used chemotherapies currently target either the highly proliferative nature of cancer cells, or specific receptors that are upregulated in cancer but often result in side effects leading to potential toxicity, and/or causing treatment failure in resistant populations. A 
new promising option for improving cancer therapies appeared, based on targeting the tumour microenvironnement ${ }^{17,18}$. For chondrosarcoma, two physical and chemical hallmarks of the tumour could also be considered as therapeutic opportunities rather than barriers, namely hypoxia and the hyaline extracellular matrix, more precisely, its high proteoglycan (PG) content.

For more than five decades, hypoxia is well recognized as a key feature in cancer progression ${ }^{11}$. Hypoxia leads to low oxygen concentration areas and then to the emergence of tumour cell subpopulations with highly aggressive phenotypes, including increased drugresistance and amplified anti-apoptotic and metastatic potential. The differences between cells in well-oxygenated normal tissue and hypoxic neoplastic cells were put to use in the development of bioreductive prodrugs activated preferentially in hypoxic regions to specifically release active cytotoxic species. ${ }^{19-23}$ This approach emerged more than three decades ago, with tirapazamine being the first hypoxia-activated prodrug (HAP) to undergo clinical trial. However, while multiple different bioreductive prodrugs demonstrating antitumour cytotoxicity against hypoxic cells, like AQ4N, apaziquone, SN30000, evofosfamide (TH-302), PR-104, etc. have been described in literature, none are so far available in the clinical setting. HAPs have in common chemical moities used as a "trigger" or "oxygen concentration sensor" ensuring activation of the prodrug through a bioreduction process via one or two electrons cellular oxidoreductases. Five different chemical groups, i.e. nitroaromatics, aromatic $N$-oxides, aliphatic $N$-oxides, quinones and transition metals, are reported in literature as triggers ${ }^{19-21}$. After the reduction step, the link between the trigger and the anti-cancer entity is cleaved and converts the non-toxic prodrug into a toxic molecule achieving hypoxia-selective killing associated with a bystander effect. By means of HAP, the therapeutic window could be extended and higher doses could be administered, providing therefore greater therapeutic potential.

In chondrosarcoma, HAP activity could be hampered by inefficient physical distribution to tumour chondrocytes due to the cartilaginous matrix barrier. Using the physical and chemical properties of the extensive cartilaginous extracellular matrix of chondrosarcoma, namely the high negative fixed charge density created by the presence of PGs, may be an attractive way of adding to these HAP therapies targeted-drug delivery. In effect, PGs are glycoproteins highly expressed in the chondrosarcoma extracellular matrix ${ }^{24}$, with numerous sulphate and 
carboxylate groups on their glycosaminoglycan moieties. This extracellular PG-targeting approach using a quaternary ammonium (QA) function was previously validated in chondrosarcoma preclinical models, with radiotracers for scintigraphic imaging 25,26 or DNAalkylating agents for therapy. ${ }^{27,28}$ More recently, this dual targeting therapy for chondrosarcoma was investigated and led to the identification of the first PG-targeting HAP, 3-(\{[bis(2chloroethyl)amino][(1-methyl-2-nitro-1H-imidazol-5-yl)methoxy]phosphoryl\}amino)- $N, N, N$ trimethyl-propane-1-aminium iodide, named ICF05016 ${ }^{29}$ (Table 1). The latter is a nitroheteroarylbased compound designed as follows: a phosphoramidic mustard functionalized with a QA function, and a 2-nitroimidazole group tethered to the phosphorous atom to trigger fragmentation and then release the bis-alkylating mustard anion by bioreduction in hypoxic tissues. Aggrecan binding of ICF05016 was confirmed from the dissociation constant determined by surface plasmon resonance (SPR), as well as hypoxic-cytotoxicity ratio (HCR) on the HEMC-SS cell line. In a HEMC-SS tumour-bearing mice model, treatment with ICF05016 provides a significant inhibition of tumour growth with no associated haematological side effects, a decrease in the mitotic index and increased DNA damage predominantly found in pimonidazolepositive hypoxic areas.

Based on these results, we intend to begin a lead optimization study of ICF05016. Herein, we report the synthesis and characterization of a series of QA-targeted phosphoramide mustard conjugates 28-32 differing by the nature of the QA function and the length of the alkyl linker binding the QA to the mustard (Table 1). Then, we screened by SPR their direct binding ability to aggrecan. Short-listed compounds were evaluated in terms of HCR in the HEMC-SS cell line to provide more knowledge on the structure-activity relationships existing between the nature of the linker and the in vitro cytotoxicity of these QA-targeted HAPs. Finally, stability in both phosphate buffer and plasma, activation and phosphoramide mustard release under reductive chemical conditions, and nitroreductase-based activation were demonstrated for the most potent derivative. 


\section{Results and discussion}

\subsection{Chemistry}

Target compounds 28-32 were obtained by quaternisation of the tertiary amine function of compounds 23-27 via a two-step reaction sequence: phosphorylation of the key hydroxymethyl 2-nitroimidazole intermediate 6 by phosphoramidic dichloride 8 , followed by the introduction of the QA alkyl chain by substitution of the remaining chloride by a series of diamines 18-22 (Scheme 1). The latter were prepared according to a Gabriel synthesis protocol starting from the appropriate alkyl halide. Briefly, N-bromoalkylphthalimides 9-12 with alkyl chain ranging from two to five carbons were produced in moderate to excellent yields (43-98\%) by alkylation of commercial potassium phthalimide with the corresponding dibromoalcane following a slightly modified procedure of the method described by $\mathrm{Hu}$ et al. $^{30}$. Nucleophilic substitution of derivatives 9-12 in acetonitrile with dimethyl-, diethyl-, diisopropyl- or benzylmethylamines afforded intermediates $\mathbf{1 3 - 1 7}^{31,32}$. Hydrazinolysis of the latters under reflux afforded directly $N$-benzyl- $N$-alkyldiamines 21a-d and 3-(piperidin-1-yl)propanamine 22 in good to excellent yields (76 to 98\%), whereas short-path distillation was required for $N, N$ dialkyldiamines 18-20 leading to moderate yields (22 to 61\%). To note, elimination of the Gabriel phthalhydrazide by-product was insured by a slightly modified work up protocol compared to the litterature ${ }^{31}$, namely a twice acidic precipitation at low temperature. Following this general threesteps procedure, the twelve diamines 18a-b, 19a-b, 20a-c, 21a-d and 22 were obtained from potassium phthalimide in overall yields ranging from 15 to $77 \%$.

The (1-methyl-2-nitro-1H-imidazol-5-yl)methanol (6) is the key intermediate for synthesis of our QA-targeted HAPs. The 1-methyl-2-nitroimidazole group was chosen as common trigger for the designed molecules. Among bioreductive nitroaryl-triggers used in HAPs, like the 4nitrobenzyl group, nitro-imidazole-, nitrofuran- and nitrothiophene-based groups, the 1-methyl2-nitroimidazole group has been used the most widely, generally showing the best tendency to undergo bioreduction and, consecutively selective cleavage at low oxygen concentrations. Hence, a 1-methyl-2-nitroimidazole group was embedded in the well-investigated evofosfamide, a HAP of bromo-isophosphoramide mustard reaching phase III clinical trials against soft tissue 
sarcoma ${ }^{33}$ and pancreatic cancer (MAESTRO study) ${ }^{34,35}$. Evofosfamide appeared for the first time in a series of nitroaromatics including nitrothiophenes and nitrofuranes, developed by Duan et al. in $2008^{36}$ and emerged as the most potent HAP of the series.

The synthesis of (1-methyl-2-nitro-1H-imidazol-5-yl)methanol (6) was built on the work published by Cavalleri et $a{ }^{37}$ and patented by Matteucci et $a l .{ }^{38}$, starting from $\mathrm{N}$-methylglycine (1) and improved later by O'Connor et al. ${ }^{39,40}$. Synthesis of 1-methyl-2-nitroimidazole derivatives appears as a challenging and fastidious task, as recently reviewed. O'Connor et al. published in $2016^{40}$ a careful and detailed description of the experimental protocol with emphasis on critical steps, precautions to be taken and the optimal reaction times for each step. More precisely, it turned out that the synthesis of the intermediate amino ester 4 represents the most critical step, associated with the lowest yields (ranging from 10-25\% according to the Matteuci et al. patent to $50 \%$ in the O'Connor protocol).

According to the procedure outlined in Scheme $1, N$-methylglycine was first converted to the corresponding ethyl ester hydrochloride salt, which in turn was $\mathrm{N}$-formylated by ethyl formate in the presence of potassium carbonate. Then, a one-pot three-steps procedure was applied to yield the 2-aminoimidazole 4: (i) $C$-formylation of the amino ester 3 at the $\alpha$-carbon by treatment with sodium hydride and ethylformate, (ii) removal of the unwanted $\mathrm{N}$-formyl group under acidic conditions at reflux, and (iii) subsequent Marckwald cyclisation with cyanamide under reflux at $\mathrm{pH} 3$ as suggested by $\mathrm{O}^{\prime}$ Connor et al. ${ }^{39}$ to minimise ester hydrolysis. This sequence finally provided the desired 2-aminoimidazole 4 in good yields (53-61 \% compared to the previous $50 \%$ yield in the $\mathrm{O}^{\prime}$ Connor protocol $\left.{ }^{39,40}\right)$. Then, diazotization of the amino group in the presence of excess sodium nitrite afforded nitroester 5 in a $75 \%$ yield. Finally, reduction of the ester function with $\mathrm{LiBH}_{4}$ formed in situ via the metathesis reaction between $\mathrm{NaBH}_{4}$ and $\mathrm{LiBr}$, allowed to obtain compound 6 in $68 \%$ yield. $\mathrm{LiBH}_{4}$ was reported as a selective reducing agent for esters, with reducing power greatly enhanced by utilizing ether-type solvents containing methanoli1. In our procedure, a mixture of $\mathrm{LiBH}_{4}-\mathrm{THF}-\mathrm{MeOH}$ was used with a strict control of the reaction medium temperature (below $10^{\circ} \mathrm{C}$ ) in order to avoid the reduction of the nitro function.

Tertiary amine derivatives 23-27 were synthesized via a one-pot reaction according to a modified procedure of Hernick et al. ${ }^{42}$ Synthesis began with the phosphorylation of the 2- 
nitroimidazole key intermediate 6 at $-78{ }^{\circ} \mathrm{C}$ by sequential treatment with lithium bis(trimethylsilyl)amide and the electrophile phosphorylating agent $\mathbf{8}$ (prepared according to a literature procedure ${ }^{43}$, on a $10 \mathrm{~g}$ scale from commercially available $N, N$-bis(2-chloroethyl)amine hydrochloride salt (7)). Then, addition of the appropriate diamine 18-22 ensured the formation of the corresponding phosphoramide 23-27. For accurate management of this one-pot procedure, the progress of the reaction was monitored using ${ }^{31} \mathrm{P} N M R$, initiated at addition of the $N, N$-bis(2-chloroethyl)phosphoramidic dichloride (8). When nearly complete disappearance of dichloride 8 (used in slight excess) concurrent with the formation of the phosphoramidic monochloride intermediate was observed, the appropriate amine was added to obtain the desired compounds 23-27. For example, ${ }^{31} \mathrm{P}$ NMR monitoring for compound $\mathbf{2 4 d}$ is depicted in Figure 1: (1) at $T_{0}$, two signals at 15.59 and 15.17 ppm appeared, relative to dichloride 8 and monochloride intermediate formed respectively; (2) after $15 \mathrm{~min}$, the signal at $15.59 \mathrm{ppm}$ had almost disappeared and 2-(N,N-diethylamino)ethylamine was added; (3) only 10 min later, the intermediate was consumed giving rise to compound $\mathbf{2 4 d}$ with a signal at $17.24 \mathrm{ppm}$ and an impurity at $18.97 \mathrm{ppm}$. It should be noted that this phosphorylation step was unpredictable and not always reliable, requiring a ${ }^{31} \mathrm{P}$ NMR monitoring to control the time of consumption of dichloride 8 , ranging from 5 to $80 \mathrm{~min}$ in different experiments. We also observed that the best results, in terms of kinetic and conversion rate, were obtained when the solution of dichlorophosphoramidate 8 in THF was pre-cooled at $-78^{\circ} \mathrm{C}$ and added at once in order to avoid the undesired bis-addition of alcohol $\mathbf{6}$. We finally noted that the solubility of 2-nitroimidazole 6 in THF at $-78^{\circ} \mathrm{C}$ was a critical factor, partial solubility correlating with longer times and loweryielding phosphorylation.

Quaternization of the series of tertiary amines 23-25, 27 was achieved using alkyl iodide (methyl or ethyl iodide), leading to the corresponding ammonium derivatives 28-30, 32. For compounds 31a-h, two synthesis pathways have been considered, i.e. direct methylation or ethylation of benzyl compounds $\mathbf{2 6}$ or benzylation of dialkyl derivatives $\mathbf{2 3}$ and $\mathbf{2 4}$. In order to establish the best route, QA derivative $\mathbf{3 1 c}$ was synthesized from $\mathbf{2 6 c}$ by treatment with methyl iodide or from $\mathbf{2 3 c}$ by alkylation with freshly prepared benzyl iodide ${ }^{44}$. In the latter case, a supplementary work-up of the crude product was necessary in order to remove excess benzyle 
iodide, affording the desired product in a lower yield compared with the methyl iodide route (30\% from 23c versus 93\% from 26c). Thus, alkyl iodides (methyl or ethyl) were used for the preparation of all ammonium derivatives bearing a benzyl group within the series. It should be emphasized that the reaction took place in different ways within the series, in terms of reaction time, number of alkyl iodide equivalents required and purity status of the obtained crude product. Most QA compounds were obtained in excellent yields (mostly > $80 \%$ ), with a satisfactory purity, only after evaporation of the excess methyl or ethyl iodide. Analytical purity was evaluated by the absence of impurities revealed in the ${ }^{1} \mathrm{H}$ and ${ }^{13} \mathrm{C}$ spectra combined with ${ }^{31} \mathrm{P}$ impurities estimated at less than $5 \%$ in global integrals. However, for five compounds (i.e. $\mathbf{2 8 g}$, $29 \mathrm{~g}, 29 \mathrm{~h}, 31 \mathrm{~g}$ and $31 \mathrm{~h}$ ) belonging to the $\mathrm{n}=2$ or 3 series, ${ }^{31} \mathrm{P}$ spectra analyses revealed the presence of an impurity after ethylation emphasized by a signal at 24-25 ppm (in $\mathrm{CD}_{3} \mathrm{OD}$ ), and ranging from 6 to $15 \%$ for $\mathbf{2 8 g}, \mathbf{2 9 g}, \mathbf{2 9 h}, \mathbf{3 1 g}$, and $87 \%$ for $\mathbf{3 1}$. Purification of these QA compounds by preparative high performance liquid chromatography ( $\mathrm{C}_{18}$ column, gradient acetonitrile in water) with subsequent lyophilisation was thus required to afford analyticaly pure compounds $\mathbf{2 8 g}, \mathbf{2 9 g}, \mathbf{2 9 h}$ and $\mathbf{3 1 g}$. To better understand this side reaction, the impurity from the synthesis of compound $\mathbf{2 9 h}$ (signal at $24.35 \mathrm{ppm}$ in ${ }^{31} \mathrm{P}$ spectrum) was isolated for structure elucidation. HRMS data showed molecular ion at $\mathrm{m} / \mathrm{z} 451.1984$, which could correspond to the loss of a neutral $\mathrm{HCl}$ (36 amu). A comprehensive spectral analysis based on HRMS and $\mathrm{RMN}\left({ }^{1} \mathrm{H}\right.$, ${ }^{13} \mathrm{C}$, COSY, HSQC, ${ }^{31} \mathrm{P}$ ) was in favour of the formation of the corresponding 2-oxidediazaphospholidine obtained by intramolecular $1,5-\mathrm{N}$-alkylation of compound $29 \mathrm{~h}$. For synthesis of compound $\mathbf{3 1 h}$, total conversion of $\mathbf{2 1 d}$ required 5 days reaction in the presence of a considerable excess of ethyl iodide (100 eq.) and led to the 2-oxide-diazaphospholidine impurity as the major product (> $80 \%$ highlighted by ${ }^{31} \mathrm{P}$ spectrum) preventing obtention of $\mathbf{3 1 h}$ in sufficient yield to allow biological assessment. This unwanted intramolecular $1,5-N$-alkylation seems to be correlated with the length of the alkyl chain and/or steric hindrance of the tertiary amine substituents which hampered quaternization with ethyl iodide, requiring longer reaction time and greater excess of ethyl iodide. 


\subsection{Biology}

The interaction between synthesized QA-targeted prodrugs 28-32 and aggrecan was evaluated by Surface plasmon resonance (SPR) analyses. SPR technology has emerged as a powerful technique to investigate the interaction between low-molecular-weight molecules and target proteins and also as an effective tool for drug screening. ${ }^{45-47}$ Aggrecan $(\approx 250 \mathrm{kD})$, with approximately 150 glycosaminoglycan side chains of chondroitin sulphate and keratan sulphate, is the most abundant PG in chondrosarcoma. ${ }^{24,48} \mathrm{~A}$ preliminary screening of the different prodrugs was performed by binding level analysis (Figure 2A). Compound ICF05016 was used as positive control and its non-QA equivalent (O-[(1-methyl-2-nitro-1H-imidazol-5-yl)methyl]- $N, N$ bis(2-chloroethyl)- $N^{\prime}$-propylphosphorodiamidate named ICF05017 ${ }^{29}$ ) as negative control for aggrecan binding measurements. The hit selection by initial screening of all synthesized QA-HAP was based on at least equivalent relative binding to aggrecan (Response Units) compared with ICF05016.

Some structure-activity relationships appeared in terms of interaction with aggrecan: affinity seemed to be related more to the type of the QA function, rather than the length of the alkyl chain between the QA function and the nitrogen mustard, since the twelve short-listed compounds were of various chain lengths $(n=2,3,4,5)$. Concerning QA substituents, the first emerging conclusion was that the presence of a benzyl group enhanced the affinity to aggrecan. In fact, all synthesized compounds bearing a benzyl moiety showed a higher binding affinity than the lead compound (almost two-fold difference in relative binding, except for compounds $\mathbf{3 1 f}$ and 31c) with the best affinity obtained for analogue 31a, characterized by a pentyl chain and a benzyl-dimethyl QA function. Improved binding affinity to aggrecan was also observed with derivatives with ethyl substituents on the QA function. None isopropyl derivatives were shortlisted, suggesting that steric hindrance perhaps hampers the inter-molecular recognition process between the isopropyl QA function and aggrecan.

Based on this selection criterion, twelve hits with Response Units over 24 were further evaluated to determine their dissociation constants $\left(K_{D}\right)$ in a concentration-dependent secondary experiment (Figure $2 B$ ). This analysis yielded $K_{D}$ values ranging from $2.10 \pm 0.13$ to $5.03 \pm 0.21$ 
$\mathrm{mM}$ (Table 1) for all selected prodrugs, which demonstrates fairly similar affinity for aggrecan as ICF05016.

The selected prodrugs were evaluated for antiproliferative activity (i.e., Growth Inhibiting Concentration 50: IC 50 ) respectively to ICF05016 and evofosfamide, under normoxic and hypoxic conditions using the human extraskeletal myeloid chondrosarcoma cell line (HEMC-SS). The IC ${ }_{50}$ values for all tested compounds are given in Table 2 and confirmed their relevance as hypoxiaactivated prodrugs. Based on the inhibition of proliferation, almost all compounds were more potent than ICF05016, with a higher activity observed in hypoxia compared to normoxia. Hypoxiccytotoxic ratio (HCR, IC 50 under normoxia vs. $\mathrm{IC}_{50}$ under hypoxia) was maintained and even increased, compared with the HCR of 7 obtained for ICF05016. Substitution of methyl groups by ethyl on the QA function or modification of the alkyl chain length did not lead to significant change in potency or in hypoxic selectivity of the prodrugs, as compared with ICF05016. However, substitution of one methyl by a benzyl group appears more effective in terms of hypoxic selectivity, as for all benzylated prodrugs (31a-g) selectivity was maintained and even increased of 2-fold to 3-fold for three compounds, mainly for compound 31f, emerging as the most effective $(H C R=24)$. Compound $31 f$ exhibited selectivity for hypoxia similar to evofosfamide with a HCR of 23 in HEMC-SS cells. However, the potency of evofosfamide on HEMC-SS cells in normoxia was higher $\left(\mathrm{IC}_{50}=2.9 \pm 1.5 \mu \mathrm{M}\right)$ compared to compound $31 \mathrm{f}\left(\mathrm{IC}_{50}=\right.$ $40.7 \pm 8.8 \mu \mathrm{M})$. This cytotoxicity could be attributed to the superoxide species, generated under normoxia and is time-dependent with longer drug exposures as previously reported ${ }^{49}$. This may lead to toxicity in healthy cells, which could be expected to occur to a lesser extent with compound 31f.

\subsection{Chemical Stability in PBS and plasma}

A stability evaluation, carried out in phosphate buffer solution (10 mM, pH 7.4, 0.13\% DMSO) on compound $31 \mathrm{f}$ at $37^{\circ} \mathrm{C}$ and monitored by reversed-phase HPLC, demonstrated promising results. Compound $\mathbf{3 1 f}$ remains structurally intact under these conditions with no significant changes 
over a $24 \mathrm{~h}$ period $(<5 \%)$. Stability in rabbit plasma at $37{ }^{\circ} \mathrm{C}$ was also demonstrated by ${ }^{31} \mathrm{P}$ NMR experiments, as no cleavage or degradation over a $24 \mathrm{~h}$ period was observed (Figure 3B).

\subsection{Reductive Chemical Activation}

$A^{31}$ P NMR experiment was carried out on compound $31 \mathrm{f}$ under model physiological conditions $\left(\mathrm{pH} 7.4,37^{\circ} \mathrm{C}\right)$ to ascertain that initial reductive activation of the phosphoramidate prodrug $\mathbf{3 1 f}$ leds to the rapid formation of the corresponding phosphoramidate anion, hypothesized as being the active cytotoxic species. Prodrug $\mathbf{3 1 f}$ was proved to be stable in these conditions over a period of $24 \mathrm{~h}$. The phosphoramidate prodrug $\mathbf{3 1 f}$ was chemically reduced with 3 equivalents of sodium dithionite (0.1 M cacodylate buffer, $\mathrm{pH}$ 7.4), a reductant system used to mimick bioreduction in hypoxic tissue. Figure 3 is an example of a ${ }^{31} \mathrm{P}$ NMR stack plot showing the results from the dithionite reduction of 31f. As expected, the resonance corresponding to prodrug $\mathbf{3 1 f}$ at 17.99 ppm rapidly disappears (half-life $<2 \mathrm{~min}$ ) with the concurrent appearance of the resonance at $12.39 \mathrm{ppm}$, which corresponds to the ${ }^{31} \mathrm{P}$ signal of the substituted bis(2chloroethyl)phosphoramidate anion. The phosphoramidate anion is a highly reactive specie and give raised to the formation of a variety of by-products arising both from subsequent solvolysis reactions (bisulfite and water substitution) and cleavages of $\mathrm{P}-\mathrm{N}$ bonds ${ }^{50,51}$. At least $90 \%$ conversion of prodrug $31 \mathrm{f}$ occured in less than $8 \mathrm{~min}$ at $37{ }^{\circ} \mathrm{C}$ under chemical reductive conditions, efficiently leading to the release of the bis-alkylating mustard anion under hypoxia mimic conditions (Figure 3B).

\subsection{Bioreductive activation via nitroreductase}

Prodrug $31 \mathrm{f}$ was evaluated as substrate of an oxygen-insensitive nitroreductase from $E$. coli, to verify activation following an enzymatic reduction. This enzyme, which involves a two electrons reduction process, provides an experimental setting not affected by the environmental oxygen level. This offers the great advantage to bypass the oxygen-sensitive prodrug radical, which is reoxidised to the original prodrug in the presence of oxygen and thus hampered the phosphoramidate anion release, as observed for nitroaromatic HAPs. The activation was evaluated by incubating compound $31 \mathrm{f}$ in phosphate buffer solution $(10 \mathrm{mM}, \mathrm{pH} 7.4)$ at $37^{\circ} \mathrm{C}$ with nitroreductase in the presence of NADPH as the cofactor. This latter doesn't induce enzyme- 
free reaction, as demonstrated by HPLC analysis. Aliquots were withdrawn at various time points and analyzed by reversed-phase HPLC. The half-lives were estimated on the basis of the disappearance of the prodrug at two nitroreductase concentrations (15 and $25 \mu \mathrm{g} / \mathrm{mL}$ ) (Figure 4). For compound 31f, the both estimated half-lives were below $1 \mathrm{~min} v s$ and $15 \mathrm{~min}$ respectively for the lead ICF05016, used as a control in our experiment. Prodrugs 31f was substrate for nitroreductase and was readily reduced with at least $90 \%$ conversion after 3-5 min, showing proof of principle for this HAP strategy.

\section{Conclusions}

The aim of this work was to synthesize a series of QA-HAP conjugates differing by the nature of the PG-targeted QA function for effective chemotherapy of chondrosarcoma, a hypoxic and PGrich tumour. The present study revealed that all prodrugs led to overall improvement in hypoxic selectivity compared with ICF05016 and highlights the positive impact of a benzyl QA function on affinity to aggrecan, the most abundant PG in chondrosarcoma. Because of its attractive hypoxic

selectivity $(H C R=24)$ and cytotoxicity in hypoxia compared to that of lead ICF05016, coupled with rapid in vitro reductive activation, compound $\mathbf{3 1 f}$ emerged as the most effective HAP and will undergo further preclinical studies, including in vivo efficacy on the HEMC-SS xenograft model on mice. 


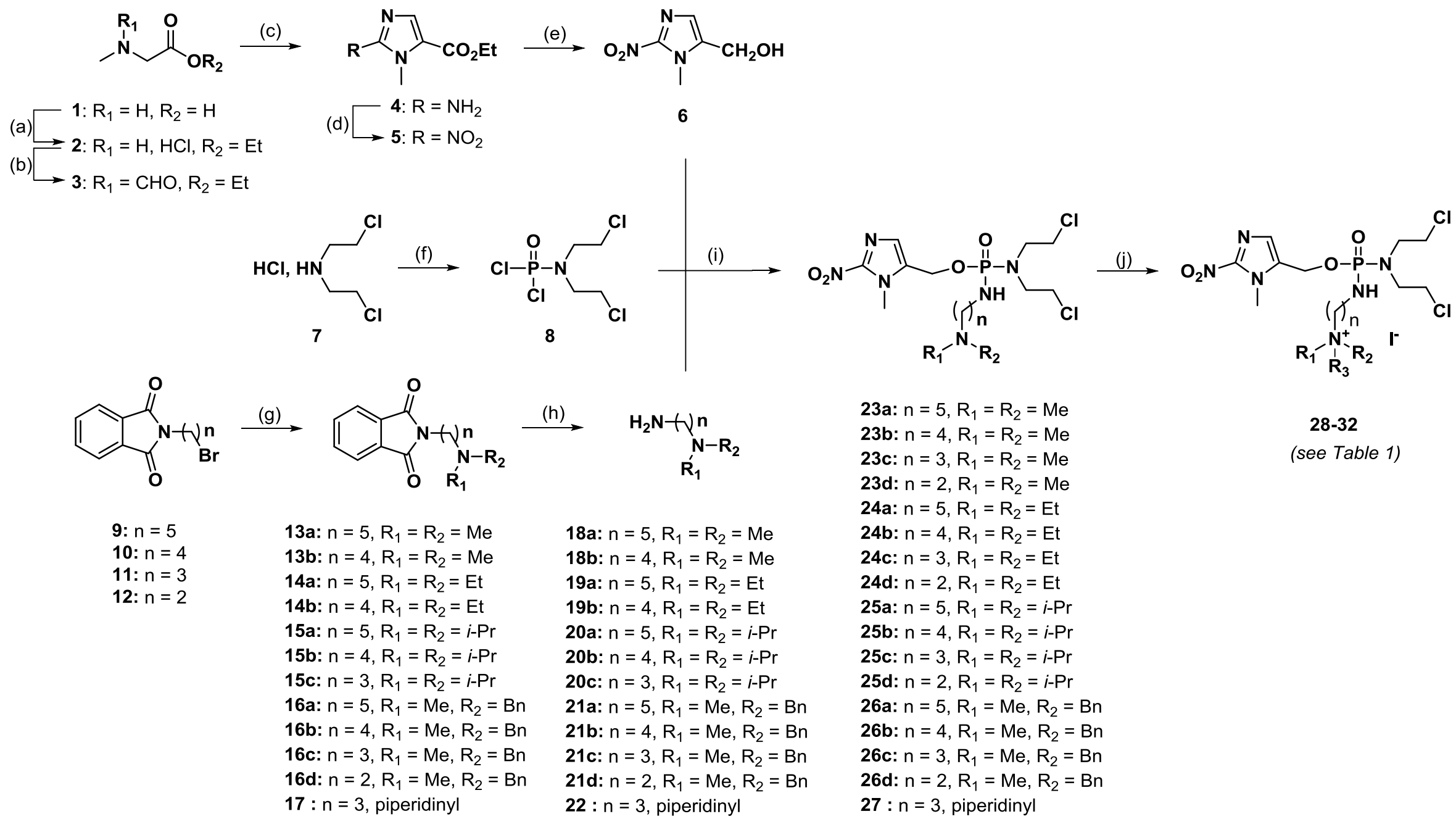

Scheme 1 : Reagents and conditions : (a) EtOH, $\mathrm{SOCl}_{2},-10{ }^{\circ} \mathrm{C}$, then $55^{\circ} \mathrm{C}$, overnight, $97 \%$; (b) ethyl formate, $\mathrm{K}_{2} \mathrm{CO}_{3}, \mathrm{EtOH}, \mathrm{rt}$, overnight, 85\%; (c) $(1)$ ethylformate, $\mathrm{NaH}$, THF anh., $0{ }^{\circ} \mathrm{C}$, rt, overnight, (2) $\mathrm{HCl} 37 \%$, EtOH, $110{ }^{\circ} \mathrm{C}, 2 \mathrm{~h}$, (3) $\mathrm{NH}_{2} \mathrm{CN}, \mathrm{EtOH} / \mathrm{H}_{2} \mathrm{O}, \mathrm{pH} 3$, reflux, $1.5 \mathrm{~h}, 61 \%$; (d) $\mathrm{NaNO}{ }_{2}, \mathrm{AcOH},-5^{\circ} \mathrm{C}$, then rt, overnight, $75 \%$; (e) $\mathrm{NaBH}_{4}, \mathrm{LiBr}, \mathrm{THF} / \mathrm{MeOH} / \mathrm{H}_{2} \mathrm{O},<10{ }^{\circ} \mathrm{C}, \mathrm{rt}, 19 \mathrm{~h}, 68 \%$; (f) $\mathrm{POCl}_{3}, 130-140{ }^{\circ} \mathrm{C}, 80 \mathrm{~h}, 57 \%$; (g) $\mathrm{HNR}_{1} \mathrm{R}_{2}, \mathrm{~K}_{2} \mathrm{CO}_{3}, \mathrm{ACN}$ or THF, reflux, 24 h, 35-93\%; (h) hydrazine hydrate (60\% aqueous solution), EtOH, reflux, $12 \mathrm{~h}, 22-99 \%$; (i) (1) LiN(TMS) 2 , THF anh., 8, -78 ${ }^{\circ} \mathrm{C}, 15-80$ min (duration determined by ${ }^{31} \mathrm{P}$ NMR monitoring); (2) amines 18-22 or commercial amines, THF anh., $-78^{\circ} \mathrm{C}, 5-75 \mathrm{~min}$ (duration determined by ${ }^{31} \mathrm{P} \mathrm{NMR}$ monitoring), 22-78\%; (j) alkyl iodide, $\mathrm{K}_{2} \mathrm{CO}{ }_{3}, \mathrm{ACN}$ anh., $\mathrm{rt}, 4-96 \mathrm{~h}, 60-$ $100 \%$. 


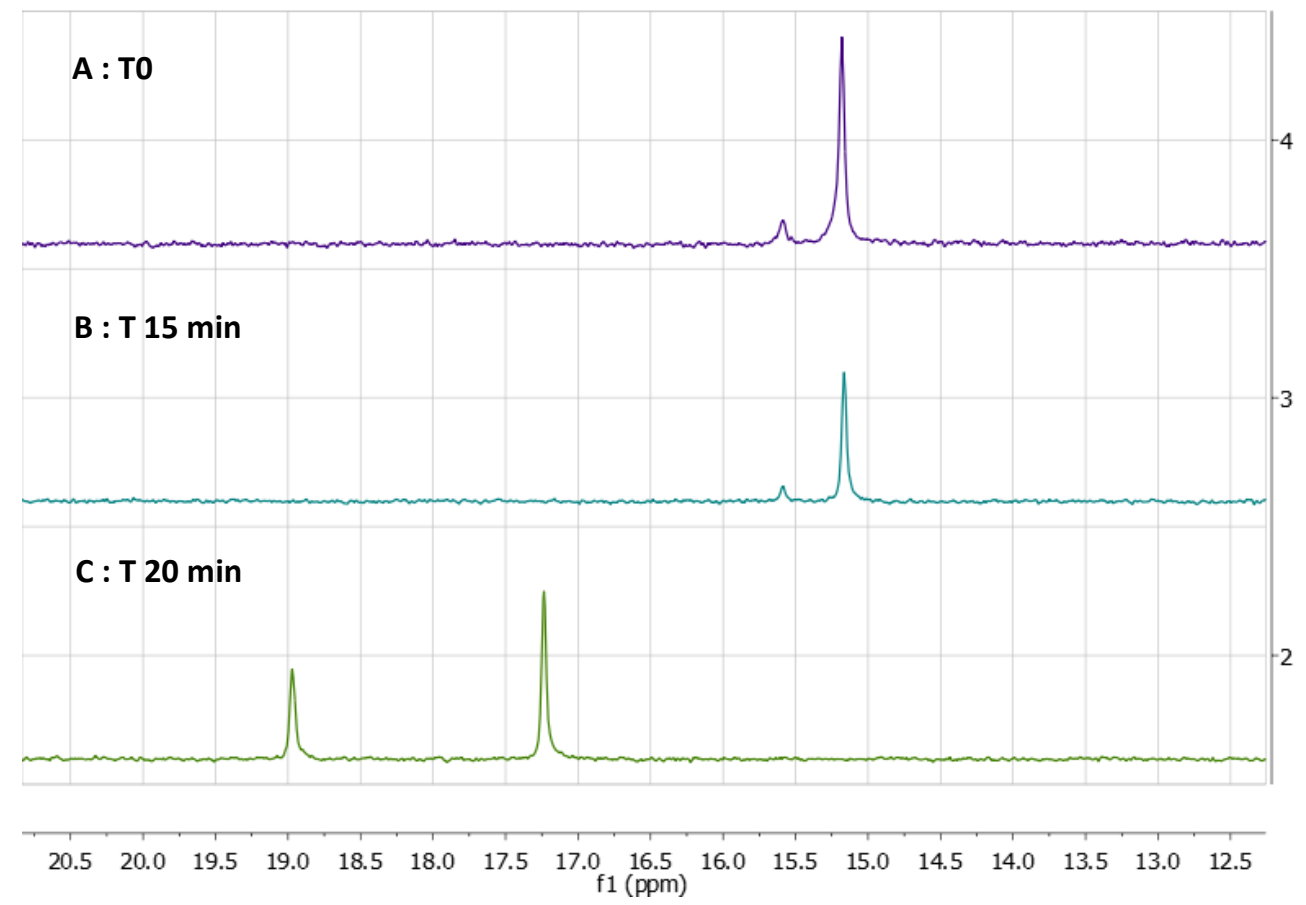

Figure 1. Example of NMR ${ }^{31} \mathrm{P}$ monitoring obtained for the synthesis of compound $24 \mathrm{~d}$.

A. Promply after addition of dichlorophosphoramidate 8, two signals at 15.59 and $15.17 \mathrm{ppm}$ appeared, relative respectively to dichloride $\mathbf{8}$ and monochloride intermediate formed;

B. After $15 \mathrm{~min}$, phosphorylation reached an optimal ratio $\sim 0.1 / 1$ between the remaining dichlorophosphoramidate 8 and the formed intermediate.

C. After the addition of 2-(N,N-diethylamino)ethylamine, the two signals at 15.59 and 15.17 disappeared immediately, generating the corresponding tertiary amine prodrug $\mathbf{2 4 d}$ with a signal at $17.24 \mathrm{ppm}$ and an impurity at $18.97 \mathrm{ppm}$. 

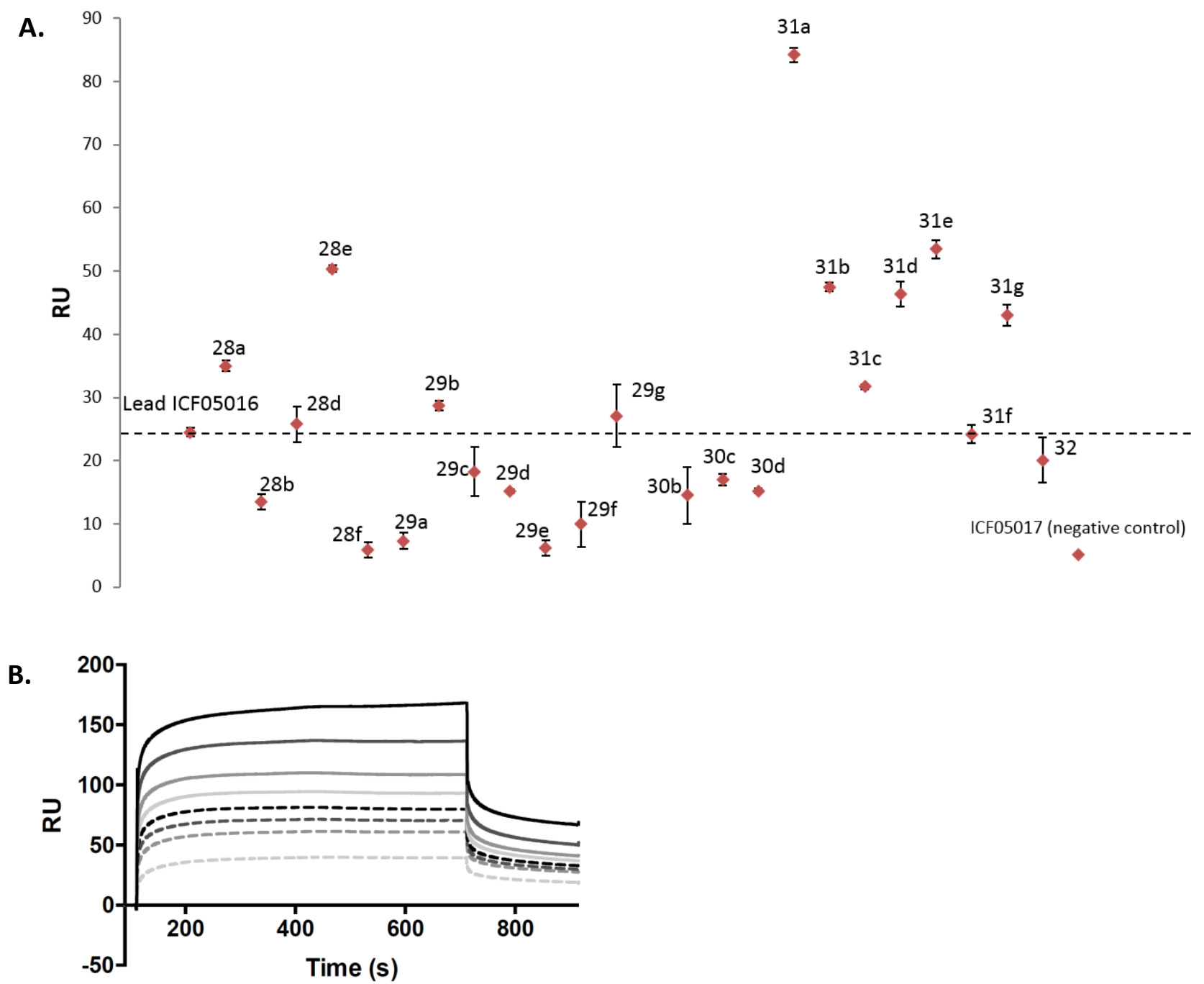

Figure 2. SPR response of compounds 28-32.

A. The SPR responses of the all QA-compounds from the first round of screening. ICF05016 was used as positive control and its non PG-targeted equivalent ICF05017 as negative control. Twelve compounds were selected, based on a Response Unit greater than or equal to the ICF05016 value (dotted line).

B. Representative sensorgram showing binding of compound 31a to immobilized aggrecan at height concentrations $(0.2,0.4,0.5,0.6,0.8,1,1.5$ and $2 \mathrm{mM}$ from bottom to top) is presented $\left(\mathrm{K}_{\mathrm{D}}=2.3 \mathrm{mM} ; \mathrm{Chi}^{2}=0.76\right)$. 


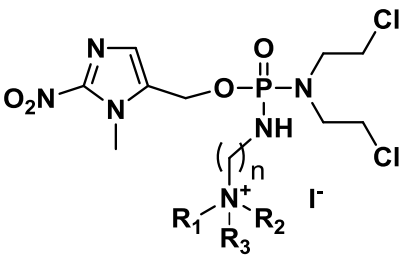

28-32

\begin{tabular}{|c|c|c|c|c|c|c|}
\hline Compd & $\mathrm{n}$ & $\mathbf{R}_{\mathbf{1}}$ & $\mathbf{R}_{\mathbf{2}}$ & $\mathbf{R}_{\mathbf{3}}$ & $\mathrm{Kd}(\mathrm{mM})$ & $\mathrm{Chi}^{2}$ \\
\hline ICF05016 & 3 & $\mathrm{Me}$ & $\mathrm{Me}$ & $\mathrm{Me}$ & $1.29 \pm 0.92$ & $0.56 \pm 0.41$ \\
\hline $28 a$ & 5 & $\mathrm{Me}$ & $\mathrm{Me}$ & $\mathrm{Me}$ & $4.22 \pm 1.25$ & $0.39 \pm 0.02$ \\
\hline $28 b$ & 4 & $\mathrm{Me}$ & Me & Me & - & - \\
\hline $28 c$ & 2 & $\mathrm{Me}$ & $\mathrm{Me}$ & Me & - & - \\
\hline $28 d$ & 5 & $\mathrm{Me}$ & $\mathrm{Me}$ & Et & $3.56 \pm 0.78$ & $0.36 \pm 0.42$ \\
\hline $28 \mathrm{e}$ & 4 & $\mathrm{Me}$ & $\mathrm{Me}$ & Et & $2.02 \pm 0.49$ & $0.24 \pm 0.18$ \\
\hline $28 f$ & 3 & $\mathrm{Me}$ & $\mathrm{Me}$ & Et & - & - \\
\hline $28 \mathrm{~g}$ & 2 & $\mathrm{Me}$ & Me & Et & - & - \\
\hline $29 a$ & 5 & Et & Et & $\mathrm{Me}$ & - & - \\
\hline $29 b$ & 4 & Et & $\mathrm{Et}$ & $\mathrm{Me}$ & $4.97 \pm 1.41$ & $0.40 \pm 0.08$ \\
\hline $29 c$ & 3 & $\mathrm{Et}$ & Et & Me & - & - \\
\hline $29 d$ & 2 & Et & Et & Me & - & - \\
\hline $29 e$ & 5 & Et & Et & Et & - & - \\
\hline $29 f$ & 4 & Et & $\mathrm{Et}$ & $\mathrm{Et}$ & - & - \\
\hline $29 g$ & 3 & Et & Et & Et & $3.49 \pm 0.45$ & $0.35 \pm 0.32$ \\
\hline $29 h$ & 2 & Et & Et & Et & - & - \\
\hline $30 a$ & 5 & $i-\operatorname{Pr}$ & $i-\operatorname{Pr}$ & $\mathrm{Me}$ & - & - \\
\hline $30 \mathrm{~b}$ & 4 & $i-\operatorname{Pr}$ & $i-\operatorname{Pr}$ & Me & - & - \\
\hline $30 c$ & 3 & $i-\mathrm{Pr}$ & $i-\operatorname{Pr}$ & Me & - & - \\
\hline $30 d$ & 2 & $i-\operatorname{Pr}$ & $i-\mathrm{Pr}$ & $\mathrm{Me}$ & - & - \\
\hline $31 a$ & 5 & $\mathrm{Bn}$ & Me & Me & $2.55 \pm 0.35$ & $0.7 \pm 0.09$ \\
\hline $31 b$ & 4 & $\mathrm{Bn}$ & Me & $\mathrm{Me}$ & $5.27 \pm 0.21$ & $1.50 \pm 1.33$ \\
\hline $31 c$ & 3 & $\mathrm{Bn}$ & $\mathrm{Me}$ & Me & $2.99 \pm 0.57$ & $0.18 \pm 0.06$ \\
\hline 31d & 2 & $\mathrm{Bn}$ & $\mathrm{Me}$ & $\mathrm{Me}$ & $2.90 \pm 0.28$ & $1.30 \pm 0.51$ \\
\hline $31 e$ & 5 & $\mathrm{Bn}$ & Me & Et & $3.47 \pm 1.14$ & $4.85 \pm 2.92$ \\
\hline $31 f$ & 4 & $\mathrm{Bn}$ & Me & Et & $2.10 \pm 0.13$ & $0.62 \pm 0.52$ \\
\hline $31 g$ & 3 & $\mathrm{Bn}$ & $\mathrm{Me}$ & Et & ND & \\
\hline $31 \mathrm{~h}$ & 2 & $\mathrm{Bn}$ & $\mathrm{Me}$ & Et & ND* & \\
\hline 32 & 3 & \multicolumn{2}{|c|}{ piperidinyl } & $\mathrm{Me}$ & - & - \\
\hline $\begin{array}{c}\text { Evofosfamide } \\
\text { (TH-302) }\end{array}$ & & & & & & $2.9 \pm 1.5$ \\
\hline
\end{tabular}

Table 1. Binding to immobilized aggrecan by SPR. Dissociation constants $\left(K_{D}\right)$ and $\mathrm{Chi}^{2}$ were determined for each derivative by "steady-state affinity analysis". All experiments were carried out in duplicate. ND: Not Determined. * no evaluation due to low degree of purity 


\begin{tabular}{cccccccc}
\hline Compd & $\mathbf{n}$ & $\mathbf{R}_{\mathbf{1}}$ & $\mathbf{R}_{\mathbf{2}}$ & $\mathbf{R}_{\mathbf{3}}$ & Normoxia & $\begin{array}{c}\mathbf{I C}_{50}(\boldsymbol{\mu M}) \\
\text { Hypoxia }\end{array}$ & HCR \\
\hline ICF05016 & 3 & $\mathrm{Me}$ & $\mathrm{Me}$ & $\mathrm{Me}$ & $29.3 \pm 8.0$ & $4.3 \pm 1.2^{* *}$ & 7 \\
\hline $\mathbf{2 8 a}$ & 5 & $\mathrm{Me}$ & $\mathrm{Me}$ & $\mathrm{Me}$ & $25.8 \pm 6.3$ & $2.4 \pm 0.4^{* *}$ & 11 \\
$\mathbf{2 8 d}$ & 5 & $\mathrm{Me}$ & $\mathrm{Me}$ & $\mathrm{Et}$ & $15.8 \pm 7.7$ & $1.5 \pm 0.8^{* *}$ & 11 \\
$\mathbf{2 8 e}$ & 4 & $\mathrm{Me}$ & $\mathrm{Me}$ & $\mathrm{Et}$ & $10.2 \pm 0.3$ & $1.5 \pm 0.1^{* *}$ & 7 \\
$\mathbf{2 9 b}$ & 4 & $\mathrm{Et}$ & $\mathrm{Et}$ & $\mathrm{Me}$ & $13.4 \pm 4.3$ & $2.4 \pm 0.7^{* *}$ & 6 \\
$\mathbf{2 9 g}$ & 3 & $\mathrm{Et}$ & $\mathrm{Et}$ & $\mathrm{Et}$ & $9.7 \pm 3.5$ & $1.4 \pm 1.0^{* *}$ & 7 \\
$\mathbf{3 1 a}$ & 5 & $\mathrm{Bn}$ & $\mathrm{Me}$ & $\mathrm{Me}$ & $28.9 \pm 2.6$ & $2.8 \pm 1.2^{* *}$ & 10 \\
$\mathbf{3 1 b}$ & 4 & $\mathrm{Bn}$ & $\mathrm{Me}$ & $\mathrm{Me}$ & $18.0 \pm 2.6$ & $1.8 \pm 0.9^{* *}$ & 10 \\
$\mathbf{3 1 c}$ & 3 & $\mathrm{Bn}$ & $\mathrm{Me}$ & $\mathrm{Me}$ & $5.4 \pm 0.9$ & $0.4 \pm 0.1^{* *}$ & 14 \\
$\mathbf{3 1 d}$ & 2 & $\mathrm{Bn}$ & $\mathrm{Me}$ & $\mathrm{Me}$ & $6.4 \pm 2.1$ & $1.1 \pm 0.4^{* *}$ & 6 \\
$\mathbf{3 1 e}$ & 5 & $\mathrm{Bn}$ & $\mathrm{Me}$ & $\mathrm{Et}$ & $12.9 \pm 3.5$ & $0.8 \pm 0.3^{* *}$ & 16 \\
$\mathbf{3 1 f}$ & 4 & $\mathrm{Bn}$ & $\mathrm{Me}$ & $\mathrm{Et}$ & $40.7 \pm 8.8$ & $1.7 \pm 0.9^{* *}$ & 24 \\
$\mathbf{3 1 g}$ & 3 & $\mathrm{Bn}$ & $\mathrm{Me}$ & $\mathrm{Et}$ & $20.8 \pm 8.7$ & $2.1 \pm 1.6^{* *}$ & 10 \\
\hline Evofosfamide & & & & & $2.9 \pm 1.5$ & $0.13 \pm 0.02^{* *}$ & 23 \\
(TH-302) & & & & & & &
\end{tabular}

Table 2. Cytotoxicity of HAP derivatives on HEMC-SS cells in normoxic $\left(21 \% \mathrm{O}_{2}\right)$ and hypoxic $\left(\mathrm{N}_{2}, \mathbf{O}_{2}<\right.$ 0.3\%) conditions. Cultures were exposed to drugs for $24 \mathrm{~h}$ followed by incubation for $48 \mathrm{~h}$ in normoxia. Notes: ${ }^{* *}$ significant difference vs. normoxic condition, $p<0.01$. Abbreviations: $\mathrm{IC}_{50}$ : Growth Inhibiting Concentration 50 ; HCR: Hypoxic-Cytotoxic Ratio $=\mathrm{IC}_{50}$ in normoxia/IC $\mathrm{C}_{50}$ in hypoxia. 
A.

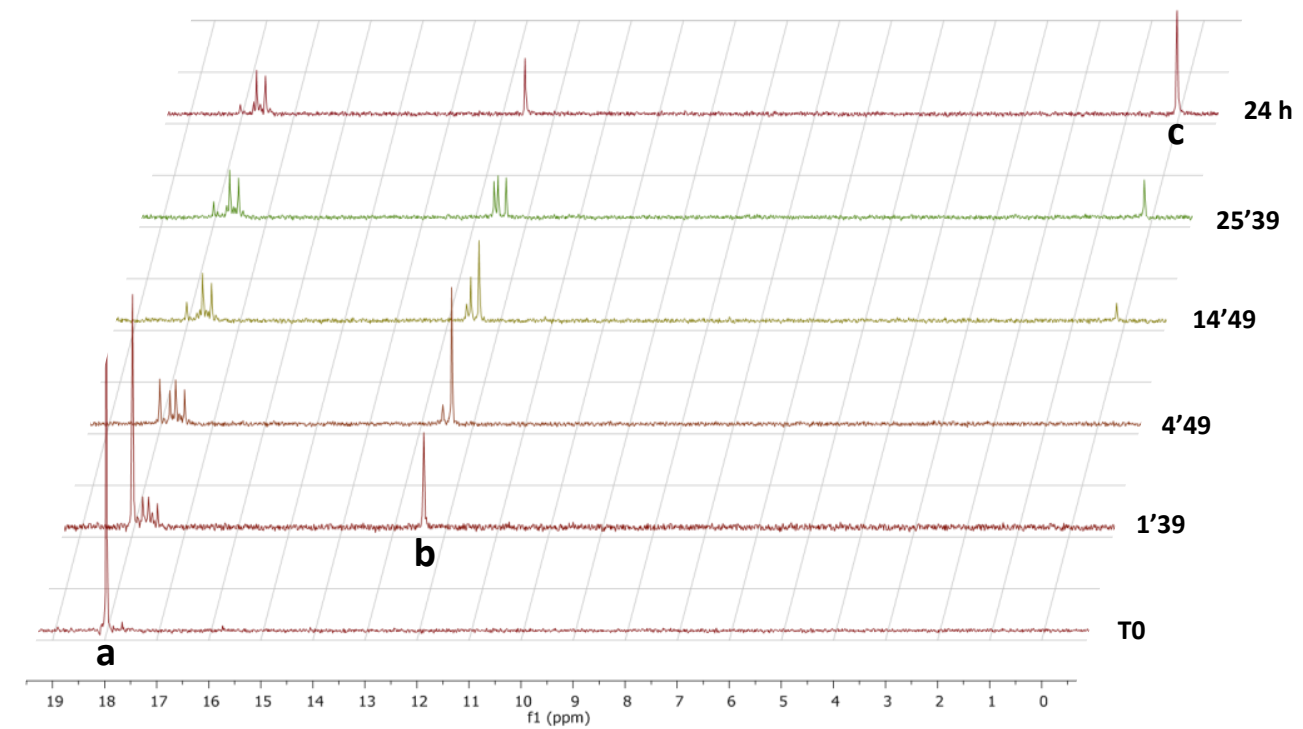

B.

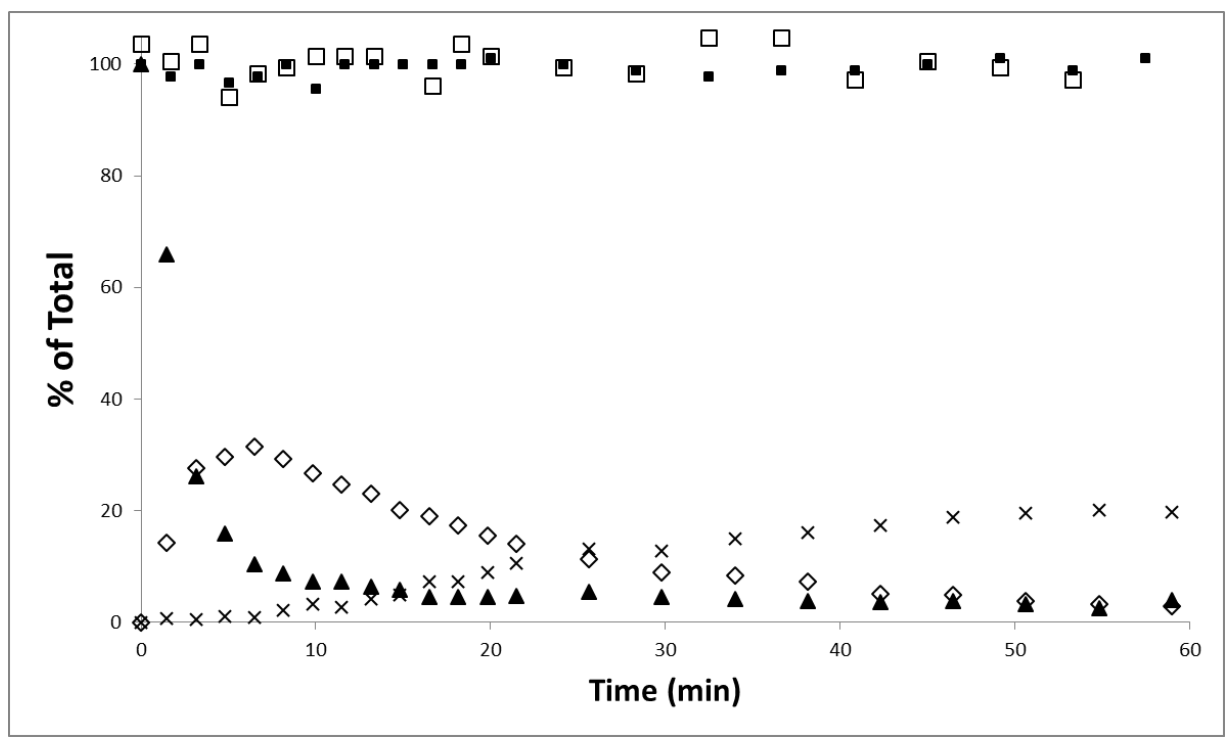

Figure 3. Drug release in reductive conditions ( 3 equiv. sodium dithionite, $\mathrm{CH}_{3} \mathrm{CN} / 0.1 \mathrm{M}$ cacodylate buffer, $\mathrm{pH} 7.4,37^{\circ} \mathrm{C}$ ) and stability in plasma assessed by NMR ${ }^{31} \mathrm{P}$ : A. Stacked NMR ${ }^{31} \mathrm{P}$ spectra; a. prodrug 31f, 17.99 ppm; b. phosphoramidate anion, 12.39 ppm (proven by MS-HPLC, data not shown); c. inorganic phosphate, $0 \mathrm{ppm}$. Other signals are relatives to solvolysis, buffer and reductive adducts or transient unknown by-products. Chemical shifts are reported relative to the $\mathrm{Ph}_{3} \mathrm{PO}$ reference. $\mathrm{B}$. Representative time course of phosphoramide $31 \mathbf{f}$ cleavage $(\boldsymbol{\Delta})$, substituted bis(2-chloroethyl)phosphoramidate anion formation $(\diamond)$ and inorganic phosphate formation $(x)$ upon incubation of the prodrug with sodium dithionite in cacodylate buffer; Stability of phosphoramide $\mathbf{3 1 f}$ in cacodylate buffer ( $\square$ ) and in rabbit plasma ( $\square$ ). Data points were measured from NMR ${ }^{31} \mathrm{P}$ areas (average of two runs). 


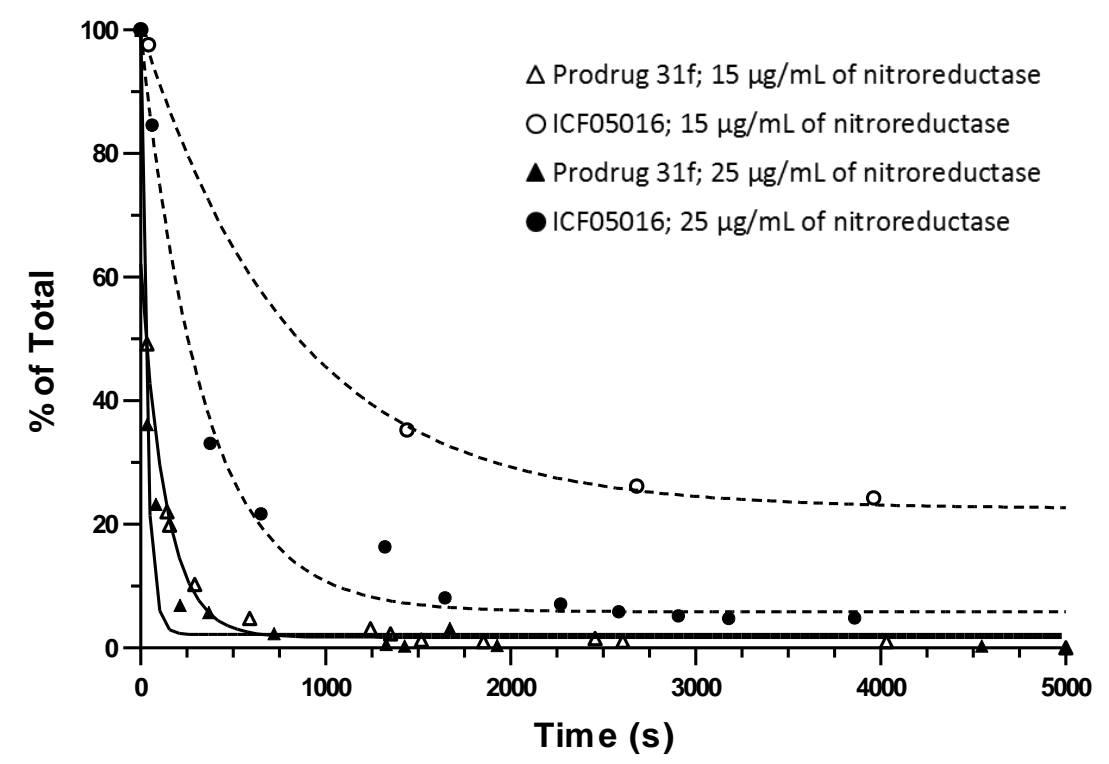

Figure 4. Percent of prodrugs $\mathbf{3 1 f}$ and ICF05016 remaining after incubation in phosphate buffer (pH 7.4, $37^{\circ} \mathrm{C}$ ) with nitroreductase in the presence of NADPH. Reactions were followed by RP-HPLC at $322 \mathrm{~nm}$. The lines represent the best-fit values calculated from GraphPadPrism. 


\section{Experimental protocols}

\subsection{Synthesis}

All commercially available reagents and solvents were purchased the following commercial suppliers: Sigma Aldrich (Saint-Quentin Fallavier, France), Acros Organics (Geel, Belgium), Fisher Scientific (Illkirch, France), Carlo Erba Reagents (Val de Reuil, France), VWR (Fontenay-sous-Bois, France) and Alfa Aesar (Karlsruhe, Germany) and were used without further purification. All solvents were dried using common techniques. Air and moisture sensitive reactions were carried out under anhydrous argon atmosphere. Analytical thin-layer chromatography (TLC) was performed on precoated silica gel aluminium plates (60 $\mathrm{F}_{254}, 0.2 \mathrm{~mm}$ thick, Macherey or SDS) using the indicated solvent mixture expressed as volume/volume ratios. The plates were visualized with ultraviolet light $(254 \mathrm{~nm})$ and (or) by development with ninhydrine ethanolic solution (0.2\%) or a 4-(4'-nitrobenzyl)pyridine (NBP)/potassium hydroxide dyeing reagent used for the determination of alkylating agents (the chromatography plate was immersed in the NBP solution ( $2.5 \%$ in acetone), heated for few min and then immersed in potassium hydroxide solution (10\% in methanol)). Column chromatography was performed on silica gel 60A normal phase, 35-70 $\mu \mathrm{m}$ (Merck or SDS or Carlo Erba). Uncorrected melting points (mp) were measured on an electrothermal capillary Digital Melting Point Apparatus (IA9100, Bibby Scientific, Roissy, France). Infrared spectra (IR) were recorded in the range $4000-600 \mathrm{~cm}^{-1}$ on a IS10 with attenuated total reflectance (ATR) accessory Nicolet (Fisher Scientific). Nuclear magnetic resonance spectra (1H NMR and 13C NMR) were performed on a Bruker AM 200 spectrometer (200 MHz for $1 \mathrm{H}, 50 \mathrm{MHz}$ for 13C), a Broker Avance DPX300 spectrometer (300 MHz for $1 \mathrm{H}, 75$ $\mathrm{MHz}$ for $13 \mathrm{C}$ ) or a Bruker DRX 500 spectrometer $(500 \mathrm{MHz}$ for $1 \mathrm{H}, 125 \mathrm{MHz}$ for 13C) (Bruker Biospin SAS, Wissembourg, France). Chemical shift values $(\delta)$ are quoted in parts per million (ppm) and calibrated to the deuterated solvent reference peak for ${ }^{1} \mathrm{H}$ and ${ }^{13} \mathrm{C}$ spectra. ${ }^{31} \mathrm{P}$ NMR spectra $(202 \mathrm{MHz})$ were recorded on a Bruker Avance 500 apparatus with broadband ${ }^{1} \mathrm{H}$ decoupling and chemical shifts were reported relative to a $1 \%$ phosphoric acid solution in deuterium oxide as a coaxial reference $(0 \mathrm{ppm})$. Coupling constants $(J)$ are quoted in $\mathrm{Hz}$. To describe spin multiplicity, standard abbreviations such as $s, d, d d, t, q, q t$, hept, td, m, br.s referring to singlet, doublet, doublet of doublet, triplet, quartet, quintet, heptuplet, doublet of 
triplet, multiplet, broad singlet respectively, are used. When necessary, chemical shifts assignments in ${ }^{1} \mathrm{H}$ and ${ }^{13} \mathrm{C}$ spectra were supported by two dimensional NMR experiments (COSY and HSQC). Compounds were analyzed by High-Resolution Mass Spectrometry in positive mode (HRMS, Waters ${ }^{\circledR}$ Micromass $^{\circledR}$ Q-Tof micro ${ }^{\mathrm{TM}}$ Mass Spectrometer, UCA-Partner, Clermont Auvergne University, Clermont-Ferrand, France). Preparative high performance liquid chromatography was performed on a CombiflashEZprep (Teledyne ISCO). The purification of QAderivatives was carried out on a $\mathrm{C}_{18}$ column using the following conditions: total experiment time: 30 min, flow rate $=15 \mathrm{~mL} / \mathrm{min}$, eluent mixture: $\mathrm{H}_{2} \mathrm{O} / \mathrm{MeCN}(\mathrm{v} / \mathrm{v})$, gradient: 95/5 for 2 min, then $95 / 5 \rightarrow 70 / 30$ for $6 \mathrm{~min}$, then 70/30 for $2 \mathrm{~min}$, then 70/30 $\rightarrow 60 / 40$ for $6 \mathrm{~min}$, then 60/40 for 3 $\min$, and 60/40 $\min \rightarrow 10 / 90$ for $11 \mathrm{~min}, \lambda=254$ and $323 \mathrm{~nm}$.

Abbreviations: ACN, acetonitrile; DCM, dichloromethane; NBP, 4-(4'-nitrobenzyl)pyridine; TEA, triethylamine; THF, tetrahydrofuran; rt, room temperature.

\subsubsection{Preparation of the common required 5-hydroxymethyl-1- $\mathrm{N}$-methyl-2-nitro- $1 \mathrm{H}$-imidazole} (6)

\subsubsection{Ethyl $N$-methylglycinate hydrochloride salt (2)}

Thionyle chloride $(65 \mathrm{~mL}, 900 \mathrm{mmol})$ was added dropwise under stirring to a solution of sarcosine (1) $(20.0 \mathrm{~g}, 224 \mathrm{mmol})$ in $\mathrm{EtOH}(250 \mathrm{~mL})$ cooled in an ice-water bath, while maintaining temperature around $-10{ }^{\circ} \mathrm{C}$. Then the reaction mixture was gently heated at $55^{\circ} \mathrm{C}$ overnight until the mixture became clear. Solvent and traces of thionyl chloride were removed by evaporation under reduced pressure and the solid residue was washed with $\mathrm{Et}_{2} \mathrm{O}(3 \times 50 \mathrm{~mL})$. The remaining solid was well dried under vacuum to afford compound 2 (33.5 g, $218 \mathrm{mmol}$ ) as a white powder, which was used in the next step without further purification. Yield 97\%; mp $126^{\circ} \mathrm{C}$ (Lit. $.^{52} \mathrm{mp} 125-$ $127^{\circ} \mathrm{C}$ ); IR (ATR) $\vee \mathrm{cm}^{-1}$ 2970-2440, 1742, 1229; $\left.{ }^{1} \mathrm{H} \mathrm{NMR} \mathrm{(CDCl} 3,400 \mathrm{MHz}\right) \delta 9.64$ (br.s, $2 \mathrm{H}, \mathrm{NH}_{2}{ }^{+}$), $4.24\left(\mathrm{q}, 2 \mathrm{H},{ }^{3} \mathrm{~J}=7.1 \mathrm{~Hz}, \underline{\mathrm{C}}_{2} \mathrm{CH}_{3}\right), 3.84\left(\mathrm{t}, 2 \mathrm{H},{ }^{3} \mathrm{~J}=5.7 \mathrm{~Hz}, \mathrm{NH}_{2}{ }^{+} \underline{\mathrm{C}}_{2}\right), 2.80\left(\mathrm{t}, 3 \mathrm{H},{ }^{3} \mathrm{~J}=5.2 \mathrm{~Hz}, \mathrm{NH}_{2}{ }^{+} \underline{\mathrm{H}}_{3}\right)$, $1.26\left(\mathrm{t}, 3 \mathrm{H},{ }^{3} \mathrm{~J}=7.1 \mathrm{~Hz}, \mathrm{CH}_{2} \underline{\mathrm{C}}_{3}\right) ;{ }^{13} \mathrm{C} \mathrm{NMR}\left(\mathrm{CDCl}_{3}, 101 \mathrm{MHz}\right) \delta 166.18\left(\mathrm{CO}_{2}\right), 62.62\left(\underline{\mathrm{CH}}_{2} \mathrm{CH}_{3}\right), 48.94$ $\left(\mathrm{NH}_{2}{ }^{+} \mathrm{CH}_{2}\right), 33.34\left(\mathrm{NH}_{2}{ }^{+} \mathrm{CH}_{3}\right), 14.03\left(\mathrm{CH}_{2} \mathrm{CH}_{3}\right)$. 


\subsubsection{Ethyl $N$-formyl- $N$-methylglycinate (3)}

Ethyl N-methylglycinate hydrochloride salt (2) (30.0 g, $195 \mathrm{mmol})$ was suspended in a mixture of EtOH (200 mL) and ethyl formate $(126 \mathrm{~mL})$. Potassium carbonate $(40.6 \mathrm{~g}, 294 \mathrm{mmol})$ was added under vigorous stirring and the suspension was stirred at rt overnight. The reaction mixture was then filtered and the precipitate was washed with EtOH $(150 \mathrm{~mL})$. The filtrate was concentrated and dissolved in a minimum amount of water $(10 \mathrm{~mL})$, followed by extraction with EtOAc $(4 \times 200$ $\mathrm{mL}$ ). The combined organic layers were dried over $\mathrm{MgSO}_{4}$, filtered and concentrated under reduced pressure to afford compound 3 (24.3 g, $167 \mathrm{mmol})$ as a pale yellow liquid. Yield $85 \%$; ${ }^{1} \mathbf{H}$ NMR $\left(\mathrm{CDCl}_{3}, 500 \mathrm{MHz}\right) \delta$ (two rotamers) 7.93 and $7.86(\mathrm{~s}, 1 \mathrm{H}, \mathrm{CHO}), 4.04$ and $4.02(\mathrm{q}, 2 \mathrm{H}, 3 \mathrm{~J}=7.2$ $\left.\mathrm{Hz}, \mathrm{CH}_{2} \mathrm{CH}_{3}\right), 3.91$ and $3.85\left(\mathrm{~s}, 2 \mathrm{H}, \mathrm{NCH}_{2}\right), 2.87$ and $2.74\left(\mathrm{~s}, 3 \mathrm{H}, \mathrm{NCH}_{3}\right), 1.12$ and $1.10(\mathrm{t}, 3 \mathrm{H}, 3 \mathrm{~J}=7.1$ $\left.\mathrm{Hz}, \mathrm{CH}_{2} \underline{\mathrm{C}}_{3}\right) ;{ }^{13} \mathrm{C}$ NMR $\left(\mathrm{CDCl}_{3}, 75 \mathrm{MHz}\right) \delta$ (two rotamers) 168.76, $168.31\left(\mathrm{CO}_{2}\right), 163.09,162.85$ (CHO), 61.62, $61.29\left(\mathrm{OCH}_{2} \mathrm{CH}_{3}\right), 50.93,45.72\left(\mathrm{NCH}_{2}\right), 35.10,30.76\left(\mathrm{NCH}_{3}\right), 14.09\left(\mathrm{OCH}_{2} \underline{\mathrm{CH}_{3}}\right)$.

\subsubsection{Ethyl 2-amino-1- $\mathrm{N}$-methyl-1H-imidazole-5-carboxylate (4)}

To a solution of $N$-formyl sarcosine ethyl ester (3) (29.6 g, $204 \mathrm{mmol}$ ) in an equal mixture of ethyl formate and THF $(190 \mathrm{~mL})$ with cyclohexane $(12 \mathrm{~mL})$, was added slowly $\mathrm{NaH}(60 \%$ wt in mineral oil, $12.5 \mathrm{~g}, 313 \mathrm{mmol}$ ) at room temperature. After the addition was completed and hydrogen release stopped, the reaction mixture was allowed to stirred during $3.5 \mathrm{~h}$. The reaction mixture was concentrated under vacuum. The obtained solid was suspended in a solution of EtOH (250 $\mathrm{mL}$ ) containing concentrated aq. $\mathrm{HCl} 32 \%(61 \mathrm{~mL})$ and refluxed for $2 \mathrm{~h}$. The hot reaction mixture was filtered and the resulting colourless solid was washed with boiling EtOH $(2 \times 150 \mathrm{~mL})$. The filtrate was concentrated under vacuum and diluted with a mixture of $\mathrm{EtOH} /$ water $(500 \mathrm{~mL}$, $70 / 30, v / v)$. The $\mathrm{pH}$ of the solution was adjusted to 3, using an aqueous $5 \mathrm{M}$ solution of $\mathrm{NaOH}$ and cyanamide $(17.5 \mathrm{~g}, 416 \mathrm{mmol})$ was added. The resulting mixture was refluxed for $1.5 \mathrm{~h}$, then cooled to rt and concentrated under reduced pressure to approximately $1 / 8$ of the initial volume. The $\mathrm{pH}$ of the remaining solution was adjusted to 9-10 with a saturated aqueous solution of potassium carbonate, after cooling in an ice-water bath. The precipitate formed was removed by filtration, washed with water $(2 \times 10 \mathrm{~mL})$ and dried under vacuum at $40{ }^{\circ} \mathrm{C}$ overnight to afford compound 4 (16.9 g, $99.9 \mathrm{mmol})$ as a pale yellow to orange solid. A supplementary fraction can be yielded after extraction of the remaining filtrate with ethyl acetate $(3 \times 100 \mathrm{~mL})$. The combined 
organic layers were dried over $\mathrm{MgSO}_{4}$, filtered and evaporated under reduced pressure. The residue was purified by column chromatography on silica gel using ethyl acetate/ethanol (95/5, v/v with $1 \% \mathrm{NH}_{4} \mathrm{OH}$ ) as eluent to yield compound 4 (3.78 g, $\left.22.3 \mathrm{mmol}\right)$. Yield 61\%; $\mathbf{R f} 0.33\left(\mathrm{SiO}_{2}\right.$,

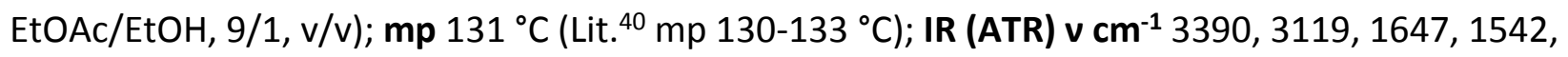
1168, 750, 737; ${ }^{1} \mathrm{H}$ NMR ( $\left.\mathrm{CDCl}_{3}, 400 \mathrm{MHz}\right) \delta 7.39$ (s, 1H, $\mathrm{CH}_{\text {Ar }}$ ), 4.66 (br.s, 2H, NH ), 4.25 (q, 2H, $\left.{ }^{3} \mathrm{~J}=7.1 \mathrm{~Hz}, \underline{\mathrm{C}}_{2} \mathrm{CH}_{3}\right), 3.65\left(\mathrm{~s}, 3 \mathrm{H}, \mathrm{NCH}_{3}\right), 1.32\left(\mathrm{t}, 3 \mathrm{H},{ }^{3} \mathrm{~J}=7.1 \mathrm{~Hz}, \mathrm{CH}_{2} \underline{\mathrm{C}}_{3}\right.$ ); ${ }^{13} \mathrm{C}$ NMR (DMSO- $d_{6}, 126$ $\mathrm{MHz}) \delta 159.68(\mathrm{CO}), 154.27\left(\mathrm{C}_{\mathrm{ArNH}} \mathrm{NH}_{2}\right), 136.02\left(\mathrm{CH}_{\mathrm{Ar}}\right), 116.88(\underline{\mathrm{C}} \mathrm{Ar} \mathrm{CO}), 58.82\left(\mathrm{OCH}_{2}\right), 30.17\left(\mathrm{NCH}_{3}\right)$, $14.30\left(\mathrm{CH}_{2} \mathrm{CH}_{3}\right)$.

\subsubsection{Ethyl 1-N-methyl-2-nitro-1H-imidazole-5-carboxylate (5)}

To a solution of sodium nitrite $(18.3 \mathrm{~g}, 266 \mathrm{mmol})$ in water $(55 \mathrm{~mL})$ cooled around $-5^{\circ} \mathrm{C}$ in an icesalt bath, was added dropwise a solution of the amino ester $4(6.42 \mathrm{~g}, 38.0 \mathrm{mmol})$ in acetic acid $(42 \mathrm{~mL})$. The temperature was allowed to rise gradually to rt and the reaction mixture was stirred overnight. The reaction mixture was extracted with dichloromethane $(3 \times 50 \mathrm{~mL})$. The combined organic layers were dried over $\mathrm{MgSO}_{4}$, filtered and evaporated under reduced pressure. The residue was purified by column chromatography on silica gel using cyclohexane/ethyl acetate $(7 / 3, v / v)$ as eluent. After concentration under vacuum, the residue was washed with water $(2 \times$ $50 \mathrm{~mL}$ ). The combined organic layers were dried over $\mathrm{MgSO}_{4}$, filtered and evaporated under reduced pressure to yield nitro ester 5 as yellow crystals $(5.67 \mathrm{~g}, 28.5 \mathrm{mmol})$. Yield 75\%; mp 56$58{ }^{\circ} \mathrm{C}$ (Lit. 56-58 ${ }^{\circ} \mathrm{C}^{40}$ and $\left.65-66^{\circ} \mathrm{C}^{37}\right)$; Rf $0.40\left(\mathrm{SiO}_{2}\right.$, cyclohexane/ethyl acetate, 7/3, v/v); IR (ATR)

v cm ${ }^{-1}$ 1723, 1552, 1486, 1519, 1364, 1233, 767; ${ }^{1} \mathbf{H}$ NMR (CDCl 3,300 MHz) $\delta 7.70$ (s, 1H, $\left.\mathrm{CH}_{\mathrm{Ar}}\right)$, $4.39\left(\mathrm{q}, 2 \mathrm{H},{ }^{3} \mathrm{~J}=7.1 \mathrm{~Hz}, \mathrm{OC}_{2} \mathrm{CH}_{3}\right), 4.31\left(\mathrm{~s}, 3 \mathrm{H}, \mathrm{NCH}_{3}\right), 1.39\left(\mathrm{t}, 3 \mathrm{H},{ }^{3} \mathrm{~J}=7.1 \mathrm{~Hz}, \mathrm{OCH}_{2} \mathrm{C}_{3}\right) ;{ }^{13} \mathrm{C} \mathrm{NMR}$ (DMSO-d $\left.d_{6}, 126 \mathrm{MHz}\right) \delta 158.71(\mathrm{CO}), 147.61\left(\mathrm{C}_{\mathrm{Ar}} \mathrm{NO}_{2}\right), 133.70\left(\mathrm{CH}_{\mathrm{Ar}}\right), 126.07\left(\mathrm{C}_{\mathrm{Ar}} \mathrm{CO}\right), 61.34\left(\mathrm{OCH}_{2}\right)$, $35.14\left(\mathrm{NCH}_{3}\right), 13.91\left(\mathrm{CH}_{2} \underline{\mathrm{C}} \mathrm{H}_{3}\right)$.

\subsubsection{5. (1-methyl-2-nitro-1H-imidazol-5-yl)methanol (6)}

The ester 5 (11.0 g, $55.2 \mathrm{mmol})$ was dissolved in a mixture of anhydrous THF/MeOH $(200 \mathrm{~mL}, 8 / 2$, $\mathrm{v} / \mathrm{v}$ ) in a $1 \mathrm{~L}$ three-necked flask fitted with a mechanical stirrer, a $500 \mathrm{~mL}$ dropping funnel, a bubbler and maintained in an ice-water bath. A suspension of $\mathrm{NaBH}_{4}(6.33 \mathrm{~g}, 167 \mathrm{mmol})$ in THF $(50 \mathrm{~mL})$ and a solution of $\operatorname{LiBr}(14.6 \mathrm{~g}, 168 \mathrm{mmol})$ in THF $(50 \mathrm{~mL})$ were cooled at $0{ }^{\circ} \mathrm{C}$, introduced 
in the same dropping funnel with water $(50 \mathrm{~m})$ and added dropwise to the nitroimidazole solution, at such a rate that the internal temperature did not exceed $10^{\circ} \mathrm{C}$. The reaction mixture was stirred at rt until total conversion of the starting nitroester 5, according to TLC monitoring $(19 \mathrm{~h})$. Ammonium chloride $(3 \mathrm{~g})$ was then added at $0{ }^{\circ} \mathrm{C}$ and stirring was prolonged for $30 \mathrm{~min}$. The precipitate was filtrated and washed with THF $(3 \times 50 \mathrm{~mL})$. After concentration under vacuum, the yellow solid was taken up in a mixture of EtOAc/MeOH $(98 / 2, v / v)$ and the resulting solution was passed through a pad of silica gel surmounted by a pad of Celite ${ }^{\circledR} 545$ to afford pure alcohol $\mathbf{6}$ as pale yellow to orange crystals $(5.91 \mathrm{~g}, 37.7 \mathrm{mmol})$. Yield $68 \%$; $\mathbf{R f} 0.50\left(\mathrm{SiO}_{2}\right.$, EtOAc); mp $140^{\circ} \mathrm{C}$ (lit. ${ }^{40} 141-143^{\circ} \mathrm{C}$ ); IR (ATR) v cm ${ }^{-1} 3231,1491,1358,1186,1040,832 ;{ }^{1} \mathbf{H}$ NMR (DMSO$\left.d_{6}, 300 \mathrm{MHz}\right) \delta 7.10\left(\mathrm{~s}, 1 \mathrm{H}, \mathrm{CH}_{\text {Ar }}\right), 5.40\left(\mathrm{t}, 1 \mathrm{H},{ }^{3} \mathrm{~J}=5.3 \mathrm{~Hz}, \mathrm{OH}\right), 4.55\left(\mathrm{~d}, 2 \mathrm{H},{ }^{3} J=5.3 \mathrm{~Hz}, \mathrm{CH}_{2} \mathrm{OH}\right), 3.93$ $\left(\mathrm{s}, 3 \mathrm{H}, \mathrm{NCH}_{3}\right) ;{ }^{13} \mathrm{C}$ NMR (DMSO-d $\left.d_{6}, 126 \mathrm{MHz}\right) \delta 145.63\left(\mathrm{C}_{\mathrm{Ar}} \mathrm{NO}_{2}\right), 138.60\left(\underline{\mathrm{C}}_{\mathrm{Ar}} \mathrm{CH}_{2}\right), 126.50\left(\mathrm{CH}_{\mathrm{Ar}}\right)$, $52.96\left(\mathrm{CH}_{2}\right), 34.03\left(\mathrm{NCH}_{3}\right)$.

\subsection{2. $N, N$-bis(2-chloroethyl)phosphoramidic acid dichloride (8)}

$\mathrm{N}, \mathrm{N}$-bis(2-chloroethyl)amine $\mathrm{HCl}(7)(10.0 \mathrm{~g}, 56.0 \mathrm{mmol})$ was refluxed at $130-140{ }^{\circ} \mathrm{C}$ in the presence of an excess of $\mathrm{POCl}_{3}(21 \mathrm{~mL}, 224 \mathrm{mmol})$ during a period of $80 \mathrm{~h}$, until a clear and brown mixture was obtained. The excess of $\mathrm{POCl}_{3}$ was removed under reduced pressure and the remaining brown residue purified by column chromatography on silica gel (EtOAc/cyclohexane, $20 / 80, v / v)$. The obtained solid was thoroughly washed with cyclohexane and dried under vacuum to afford pure compound 8 as white crystals $(8.0 \mathrm{~g}, 31 \mathrm{mmol})$. Yield $55 \%$; $\mathbf{R f} 0.39\left(\mathrm{SiO}_{2}\right.$, cyclohexane/EtOAc, 8/2, v/v); mp $57^{\circ} \mathrm{C}\left(\right.$ Lit. $\left.^{43} 57-59^{\circ} \mathrm{C}\right)$; IR (ATR) v cm ${ }^{-1} 1272,1264\left(v_{\mathrm{P}=\mathrm{O}}, \mathrm{v}_{\mathrm{C}-\mathrm{N}}\right)$, 1116, $1102\left(\mathrm{VP}_{\mathrm{P}-\mathrm{O}}, \mathrm{VPP}_{\mathrm{N}-\mathrm{N}}\right) ;{ }^{1} \mathrm{H}$ NMR $\left(\mathrm{CDCl}_{3}, 200 \mathrm{MHz}\right) \delta$ 3.841-3.51 (m, 8H); ${ }^{13} \mathrm{C} \mathrm{NMR}\left(\mathrm{CDCl}_{3}, 50 \mathrm{MHz}\right)$ $\delta 49.61\left(\mathrm{~d}, 2 \mathrm{C},{ }^{2} \mathrm{~J}_{\mathrm{C}-\mathrm{P}}=4.1 \mathrm{~Hz}, \mathrm{NCH}_{2} \mathrm{CH}_{2} \mathrm{Cl}\right), 40.91\left(\mathrm{~d}, 2 \mathrm{C},{ }^{3} \mathrm{~J}_{\mathrm{C}-\mathrm{P}}=2.7 \mathrm{~Hz}, \mathrm{NCH}_{2} \mathrm{CH}_{2} \mathrm{Cl}\right) ;{ }^{31} \mathrm{P}$ NMR $\left(\mathrm{CDCl}_{3}\right.$, $202 \mathrm{MHz}) \delta 17.42$.

\subsubsection{General procedure for the synthesis of non-targeted prodrugs 23 to 27}

To a solution of (1-methyl-2-nitro-1H-imidazol-5-yl)methanol (6) (1 eq.) in freshly distilled anhydrous THF (10 $\mathrm{mL}$ for $3 \mathrm{mmol}$ of alcohol 6) was added dropwise lithium 
bis(trimethylsilyl)amide (1M in THF, 1.1 eq.) at $-78{ }^{\circ} \mathrm{C}$ under an inert atmosphere. The reaction mixture was stirred around $5 \mathrm{~min}$ at $-78{ }^{\circ} \mathrm{C}$, and a solution of bis(2-chloroethyl)phosphoramidic dichloride (8) (1.1 eq.) in THF (3.3 mmol in $10 \mathrm{~mL}$ ), previously cooled at $-78{ }^{\circ} \mathrm{C}$, was added all at once at the same temperature $\left(T_{0}\right)$. The reaction mixture was stirred for 15 to $80 \mathrm{~min}$, before the addition of a solution of the appropriate amine 18-22 (2-2.2 eq.) in THF ( $3 \mathrm{~mL}$ for $5 \mathrm{mmol}$ of amine) and stirring was maintained at $-78^{\circ} \mathrm{C}$ for $5 \mathrm{~min}$ to $75 \mathrm{~min}$. These reaction times were determined by ${ }^{31} \mathrm{P}$ NMR monitoring for each compound. The reaction was stopped by addition of water (20 mL for $3 \mathrm{mmol}$ of alcohol 6), concentrated in vacuum and then extracted with EtOAc $\left(3 \times 50 \mathrm{~mL}\right.$ for $3 \mathrm{mmol}$ of alcohol 6). The combined organic extracts were dried over $\mathrm{MgSO}_{4}$, filtered and concentrated under reduced pressure. The residue was purified by column chromatography on silica gel using an eluent gradient (EtOAc/EtOH with TEA or $\mathrm{NH}_{4} \mathrm{OH}$ ) to afford compounds 23-27 as yellow to orange oils.

(1-methyl-2-nitro-1H-imidazol-5-yl)methyl

$N, N$-bis(2-chloroethyl)- $N^{\prime}$-[5-(dimethylamino) pentyl]phosphorodiamidate (23a)

Starting from $500 \mathrm{mg}(3.18 \mathrm{mmol})$ of alcohol 6, the coupling reaction with bis(2chloroethyl)phosphoramidic dichloride (8) was performed for $60 \mathrm{~min}$ before the addition of the prepared amine $18 \mathrm{a}(826 \mathrm{mg}, 6.34 \mathrm{mmol})$. The reaction was then stopped after $10 \mathrm{~min}$ of stirring. The crude product was purified by silica gel chromatography (EtOAc/EtOH/ $\mathrm{NH}_{4} \mathrm{OH}$ ranging from 90/10/1 to 50/50/3, v/v/v) to afford 23 a (457 mg, $0.965 \mathrm{mmol}$ ) as a yellow-orange oil. Yield 30\%;

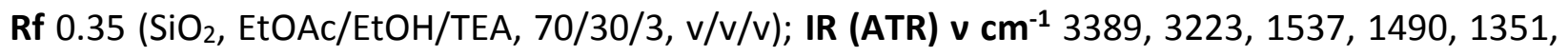
1216, 1191, 1007, 979, 960, 834, 744; ${ }^{1} \mathrm{H}$ NMR (200 MHz, CDCl $) \delta 7.19$ (s, $1 \mathrm{H}, \mathrm{CH}_{\mathrm{Ar}}$ ), 5.19 (dd, $1 \mathrm{H}$, $\left.{ }^{2} J_{\mathrm{H}-\mathrm{H}}=13.3 \mathrm{~Hz},{ }^{3} J_{\mathrm{H}-\mathrm{P}}=7.5 \mathrm{~Hz}, \mathrm{CH}^{\prime} \mathrm{O}\right), 4.98\left(\mathrm{dd}, 1 \mathrm{H},{ }^{2} J_{\mathrm{H}-\mathrm{H}}=13.3 \mathrm{~Hz},{ }^{3} \mathrm{~J}_{\mathrm{H}-\mathrm{P}}=9.0 \mathrm{~Hz}, \mathrm{CH}\right.$ "O), $4.07(\mathrm{~s}$, $\left.3 \mathrm{H}, \mathrm{NCH}_{3}\right), 3.95\left(\mathrm{td}, 1 \mathrm{H},{ }^{3} J_{\mathrm{H}-\mathrm{H}}=6.8 \mathrm{~Hz},{ }^{2} \mathrm{~J}_{\mathrm{H}-\mathrm{P}}=11.3 \mathrm{~Hz}, \mathrm{~N} \underline{\mathrm{HP}}\right), 3.64-3.51\left(\mathrm{~m}, 4 \mathrm{H}, \mathrm{N}\left(\mathrm{CH}_{2} \mathrm{C}_{2} \mathrm{Cl}\right)_{2}\right), 3.53-$ $3.25\left(\mathrm{~m}, 4 \mathrm{H}, \mathrm{N}\left(\mathrm{C}_{2} \mathrm{CH}_{2} \mathrm{Cl}\right)_{2}\right), 3.04-2.89\left(\mathrm{~m}, 4 \mathrm{H}, \underline{\mathrm{C}}_{2} \mathrm{NHP}, \mathrm{C}_{2} \mathrm{~N}\left(\mathrm{CH}_{3}\right)_{2}\right), 2.79\left(\mathrm{~s}, 6 \mathrm{H}, \mathrm{N}\left(\mathrm{C}_{3}\right)_{2}\right), 1.90-$ $1.53\left(\mathrm{~m}, 6 \mathrm{H}, \mathrm{CH}_{2} \underline{\mathrm{C}}_{2} \mathrm{C}_{2}{ }_{2} \underline{\mathrm{H}}_{2} \mathrm{CH}_{2}\right) ;{ }^{13} \mathrm{C}$ NMR (50 MHz, CDCl 3$) \delta 146.41\left(\mathrm{C}_{\mathrm{ArNO}_{2}}\right), 133.43\left(\mathrm{~d},{ }^{3} \mathrm{C}_{\mathrm{C}-\mathrm{P}}=\right.$ $\left.7.1 \mathrm{~Hz}, \underline{\mathrm{C}}_{\mathrm{Ar}} \mathrm{CH}_{2}\right), 129.11\left(\mathrm{CH}_{\mathrm{Ar}}\right), 57.62\left(\underline{\mathrm{CH}}_{2} \mathrm{~N}\left(\mathrm{CH}_{3}\right)_{2}\right), 56.44\left(\mathrm{~d},{ }^{2} J_{\mathrm{C}-\mathrm{P}}=4.4 \mathrm{~Hz}, \mathrm{CH}_{2} \mathrm{O}\right), 49.33\left(\mathrm{~d}, 2 \mathrm{C},{ }^{2} J_{\mathrm{C}-}\right.$ $\left.\mathrm{P}=3.9 \mathrm{~Hz}, \mathrm{~N}\left(\mathrm{CH}_{2} \mathrm{CH}_{2} \mathrm{Cl}\right)_{2}\right), 43.18\left(2 \mathrm{C}, \mathrm{N}\left(\underline{\mathrm{CH}}_{3}\right)_{2}\right), 42.81\left(2 \mathrm{C}, \mathrm{N}\left(\mathrm{CH}_{2} \underline{\mathrm{CH}}_{2} \mathrm{Cl}\right)_{2}\right), 40.17\left(\mathrm{CH}_{2} \mathrm{NHP}\right), 34.78$ $\left(\mathrm{NCH}_{3}\right), 30.12\left(\mathrm{~d},{ }^{3} \mathrm{~J}_{\mathrm{C}-\mathrm{P}}=6.4 \mathrm{~Hz}, \underline{\mathrm{C}} \mathrm{H}_{2} \mathrm{CH}_{2} \mathrm{NHP}\right), 23.92,23.34\left(\underline{\mathrm{C}} \mathrm{H}_{2} \underline{\mathrm{CH}}_{2} \mathrm{CH}_{2} \mathrm{~N}\left(\mathrm{CH}_{3}\right)_{2}\right) ;{ }^{31} \mathbf{P}$ NMR (202 
$\mathrm{MHz}, \mathrm{CD}_{3} \mathrm{OD}$ ) $\delta$ 18.33; HRMS (ESI) $\mathrm{m} / \mathrm{z} 473.1607[\mathrm{M}+\mathrm{H}]^{+}$(calculated for $\left[\mathrm{C}_{16} \mathrm{H}_{32} \mathrm{Cl}_{2} \mathrm{~N}_{6} \mathrm{O}_{4} \mathrm{P}\right]^{+}$ 473.1594).

\subsubsection{General procedure for the synthesis of targeted prodrugs 28 to 32}

To a solution of amine 23-27 (1 eq.) in anhydrous ACN (5 mL for 50-100 mg of amine) under an inert atmosphere, was added potassium carbonate (2.5 eq) and appropriate alkyl iodide (5-24 eq.). Stirring was maintained at $r t$ in a sealed flask for several hours until TLC monitoring showed total conversion of the initial product (further addition of alkyl iodide was sometimes necessary). The suspension was filtered and the precipitate was thoroughly washed with ACN. After evaporation of the filtrate, the residue was dissolved in acetone (10 mL for $50 \mathrm{mg}$ of amine) and the mixture was filtered to remove the remaining potassium carbonate. After evaporation to dryness under reduced pressure, the corresponding quaternary ammoniums 28-32 were obtained analytically pure or purified by preparative high performance liquid chromatography and lyophilised.

\subsubsection{1.}

5-(\{[bis(2-chloroethyl)amino][(1-methyl-2-nitro-1H-imidazol-5yl)methoxy]phosphoryl\}amino)-N,N,N-trimethylpentane-1-aminium iodide (28a)

Alkylation of amine 23a (34 mg, $71.8 \mu \mathrm{mol}$ ) with methyl iodide (24 eq.) using the standard procedure (reaction time: $4 \mathrm{~h}$ ) afforded compound 28a analytically pure, as a yellow hygroscopic

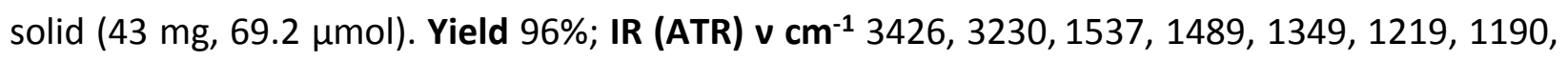
1007, 960, 835, 743; ${ }^{1} \mathrm{H}$ NMR (500 MHz, CD $30 D$ ) $\delta 7.25$ (s, $\left.1 \mathrm{H}, \mathrm{CH}_{\mathrm{Ar}}\right), 5.16\left(\mathrm{dd}, 2 \mathrm{H},{ }^{2} \mathrm{~J}_{\mathrm{H}-\mathrm{H}}=13.3 \mathrm{~Hz}\right.$, $\left.{ }^{3} J_{\mathrm{H}-\mathrm{P}}=8.2 \mathrm{~Hz}, \mathrm{CH}^{\prime} \mathrm{O}\right), 5.12\left(\mathrm{dd}, 2 \mathrm{H},{ }^{2} \mathrm{~J}_{\mathrm{H}-\mathrm{H}}=13.3 \mathrm{~Hz},{ }^{3} \mathrm{~J}_{\mathrm{H}-\mathrm{H}}=8.8 \mathrm{~Hz}, \mathrm{CH}^{\prime \prime O}\right), 4.07\left(\mathrm{~s}, 3 \mathrm{H}, \mathrm{NCH}_{3}\right), 3.67(\mathrm{td}$, $\left.4 \mathrm{H},{ }^{3} J_{\mathrm{H}-\mathrm{H}}=7.0 \mathrm{~Hz},{ }^{4} J_{\mathrm{H}-\mathrm{P}}=2.3 \mathrm{~Hz}, \mathrm{~N}\left(\mathrm{CH}_{2} \mathrm{CH}_{2} \mathrm{Cl}\right)_{2}\right), 3.54-3.32\left(\mathrm{~m}, 8 \mathrm{H}, \mathrm{N}\left(\mathrm{C}_{2} \mathrm{CH}_{2} \mathrm{Cl}\right)_{2}, \mathrm{CH}_{2} \mathrm{~N}^{+}\right), 3.19(\mathrm{~s}$, $\left.9 \mathrm{H}, \mathrm{N}^{+}\left(\mathrm{CH}_{3}\right)_{3}\right), 2.96-2.84\left(\mathrm{~m}, 2 \mathrm{H}, \underline{\mathrm{C}}_{2} \mathrm{NHP}\right), 1.84-1.77\left(\mathrm{~m}, 2 \mathrm{H}, \mathrm{CH}_{2} \mathrm{CH}_{2} \mathrm{~N}^{+}\right), 1.59$ (qt, $2 \mathrm{H},{ }^{3} \mathrm{~J}_{\mathrm{H}-\mathrm{H}}=7.2$ $\mathrm{Hz}, \underline{\mathrm{C}}_{2} \mathrm{CH}_{2} \mathrm{NHP}$ ), 1.41 (qt, $2 \mathrm{H},{ }^{3} \mathrm{H}_{\mathrm{H}-\mathrm{H}}=7.5 \mathrm{~Hz}, \underline{\mathrm{CH}}_{2} \mathrm{CH}_{2} \mathrm{CH}_{2} \mathrm{NHP}$ ); ${ }^{13} \mathrm{C}$ NMR (126 MHz, CD 30 ) $\delta$ $147.64\left(\mathrm{C}_{\mathrm{Ar}} \mathrm{NO}_{2}\right), 135.10\left(\mathrm{~d},{ }^{3} \mathrm{~J}_{\mathrm{C}-\mathrm{P}}=6.8 \mathrm{~Hz}, \underline{\mathrm{C}}_{\mathrm{Ar}} \mathrm{CH}_{2}\right), 129.27\left(\mathrm{CH}_{\mathrm{Ar}}\right), 67.81\left(\mathrm{CH}_{2} \mathrm{~N}^{+}\right), 57.73\left(\mathrm{~d},{ }^{2} J_{\mathrm{C}-\mathrm{P}}=\right.$ $\left.4.7 \mathrm{~Hz}, \mathrm{OCH}_{2}\right), 53.75,53.72,53.68\left(\mathrm{~N}^{+}\left(\mathrm{CH}_{3}\right)_{3}\right), 50.30\left(\mathrm{~d}, 2 \mathrm{C},{ }^{2} \mathrm{~J}_{\mathrm{C}-\mathrm{P}}=4.6 \mathrm{~Hz}, \mathrm{~N}\left(\mathrm{CH}_{2} \mathrm{CH}_{2} \mathrm{Cl}\right)_{2}\right), 43.24(2 \mathrm{C}$, $\left.\mathrm{N}\left(\mathrm{CH}_{2} \underline{\mathrm{CH}}_{2} \mathrm{Cl}\right)_{2}\right), 41.37\left(\mathrm{CH}_{2} \mathrm{NHP}\right), 35.23\left(\mathrm{NCH}_{3}\right), 32.19\left(\mathrm{~d},{ }^{3} \mathrm{~J}_{\mathrm{C}-\mathrm{P}}=5.5 \mathrm{~Hz}, \mathrm{CH}_{2} \mathrm{CH}_{2} \mathrm{NHP}\right), 24.37$ 
$\left(\underline{\mathrm{C}} \mathrm{H}_{2} \mathrm{CH}_{2} \mathrm{CH}_{2} \mathrm{NHP}\right), 23.58\left(\underline{\mathrm{C}}_{2} \mathrm{CH}_{2} \mathrm{~N}^{+}\right) ;{ }^{31} \mathrm{P}$ NMR (202 MHz, CD $\left.{ }_{3} \mathrm{OD}\right) \delta 18.28 ;$ HRMS (ESI) $\mathrm{m} / \mathrm{z}$ 487.1744 [M] $]^{+}$(calculated for $\left[\mathrm{C}_{17} \mathrm{H}_{34} \mathrm{Cl}_{2} \mathrm{~N}_{6} \mathrm{O}_{4} \mathrm{P}\right]^{+} 487.1751$ ).

4.1.4.2.

4-(\{[bis(2-chloroethyl)amino][(1-methyl-2-nitro-1H-imidazol-5yl)methoxy]phosphoryl\}amino)-N,N,N-trimethylbutane-1-aminium iodide (28b)

Alkylation of amine $23 \mathbf{b}(78 \mathrm{mg}, 0.171 \mathrm{mmol}$ ) with methyl iodide (12 eq.) using the standard procedure (reaction time: $4 \mathrm{~h}$ ), afforded compound $\mathbf{2 8 b}$ analytically pure, as a yellow hygroscopic solid (95 mg, $0.158 \mathrm{mmol}$ ). Yield 92\%; IR (ATR) v cm-1 3404, 3223, 1537, 1488, 1349, 1217, 1190,

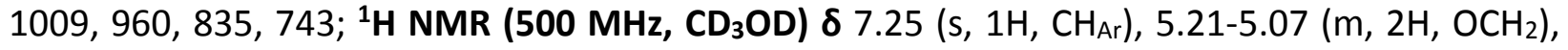
$4.07\left(\mathrm{~s}, 3 \mathrm{H}, \mathrm{NCH}_{3}\right), 3.74-3.61\left(\mathrm{~m}, 4 \mathrm{H}, \mathrm{N}\left(\mathrm{CH}_{2} \mathrm{C}_{2} \mathrm{Cl}\right)_{2}\right), 3.55-3.34\left(\mathrm{~m}, 6 \mathrm{H}, \mathrm{N}\left(\mathrm{C}_{2}{ }_{2} \mathrm{CH}_{2} \mathrm{Cl}_{2}, \mathrm{CH}_{2} \mathrm{~N}^{+}\right), 3.15\right.$ $\left(\mathrm{s}, 9 \mathrm{H}, \mathrm{N}^{+}\left(\mathrm{CH}_{3}\right)_{3}\right), 3.01-2.88\left(\mathrm{~m}, 2 \mathrm{H}, \mathrm{C}_{2} \mathrm{NHP}\right), 1.89-1.77\left(\mathrm{~m}, 2 \mathrm{H}, \mathrm{C}_{2} \mathrm{CH}_{2} \mathrm{~N}^{+}\right), 1.63-1.50$ $\left(\mathrm{C}_{2} \mathrm{CH}_{2} \mathrm{NHP}\right) ;{ }^{13} \mathrm{C}$ NMR (126 MHz, CD $\left.3 \mathrm{OD}\right) \delta 147.64\left(\mathrm{C}_{\mathrm{Ar}} \mathrm{NO}_{2}\right), 135.06$ (d, $\left.{ }^{3} \mathrm{~J}_{\mathrm{C}-\mathrm{P}}=7.2 \mathrm{~Hz}, \underline{\mathrm{Cr}}_{\mathrm{Ar}} \mathrm{CH}_{2}\right)$, $129.26\left(\mathrm{CH}_{\mathrm{Ar}}\right), 67.50\left(\mathrm{CH}_{2} \mathrm{~N}^{+}\right), 57.78\left(\mathrm{~d},{ }^{2} J_{\mathrm{C}-\mathrm{P}}=4.8 \mathrm{~Hz}, \mathrm{OCH}_{2}\right), 53.78,53.76,53.72\left(\mathrm{~N}^{+}\left(\mathrm{CH}_{3}\right)_{3}\right), 50.23$ $\left(\mathrm{d}, 2 \mathrm{C},{ }^{2} \mathrm{~J}_{\mathrm{C}-\mathrm{P}}=4.7 \mathrm{~Hz}, \mathrm{~N}\left(\underline{\mathrm{C}} \mathrm{H}_{2} \mathrm{CH}_{2} \mathrm{Cl}\right)_{2}\right), 43.23\left(2 \mathrm{C}, \mathrm{N}\left(\mathrm{CH}_{2} \mathrm{CH}_{2} \mathrm{Cl}\right)_{2}\right), 41.05\left(\mathrm{CH}_{2} \mathrm{NHP}\right), 35.25\left(\mathrm{NCH}_{3}\right), 29.41$ $\left(d,{ }^{3} \mathrm{~J}_{\mathrm{C}-\mathrm{P}}=4.6 \mathrm{~Hz}, \mathrm{CH}_{2} \mathrm{CH}_{2} \mathrm{NHP}\right), 21.36\left(\underline{\mathrm{CH}}_{2} \mathrm{CH}_{2} \mathrm{~N}^{+}\right) ;{ }^{31} \mathrm{P}$ NMR (202 MHz, CD 30 D) $\delta$ 18.25; HRMS (ESI) $\mathrm{m} / \mathrm{z} 473.1603[\mathrm{M}]^{+}$(calculated for $\left[\mathrm{C}_{16} \mathrm{H}_{32} \mathrm{Cl}_{2} \mathrm{~N}_{6} \mathrm{O}_{4} \mathrm{P}\right]^{+}$473.1594).

\subsubsection{3.}

2-(\{[bis(2-chloroethyl)amino][(1-methyl-2-nitro-1H-imidazol-5yl)methoxy]phosphoryl\}amino)-N,N,N-trimethylethane-1-aminium iodide (28c)

Alkylation of amine 23d (114 mg, $0.264 \mathrm{mmol}$ ) with methyl iodide (5 eq.) using the standard procedure (reaction time: $24 \mathrm{~h}$ ) and purification by preparative high performance liquid chromatography (gradient ACN in water) afforded compound 28c as a hygroscopic lyophilisate

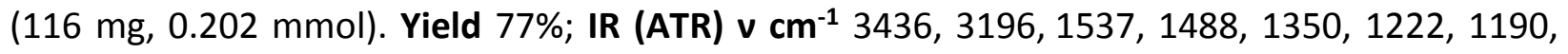
1005, 959, 835, 744; ${ }^{1} \mathrm{H}$ NMR (500 MHz, CD ${ }_{3} \mathrm{OD}$ ) 7.27 (s, $1 \mathrm{H}, \mathrm{CH}_{\mathrm{Ar}}$ ), 5.20 (dd, 2H, ${ }^{2} \mathrm{~J}_{\mathrm{H}-\mathrm{H}}=13.4 \mathrm{~Hz}$, $\left.{ }^{3} J_{\mathrm{H}-\mathrm{P}}=8.4 \mathrm{~Hz}, \mathrm{CH}^{\prime} \mathrm{O}\right), 5.17\left(\mathrm{dd}, 2 \mathrm{H},{ }^{2} \mathrm{~J}_{\mathrm{H}-\mathrm{H}}=13.4 \mathrm{~Hz},{ }^{3} \mathrm{~J}_{\mathrm{H}-\mathrm{H}}=8.3 \mathrm{~Hz}, \mathrm{CH}^{\prime \prime} \mathrm{O}\right), 4.08\left(\mathrm{~s}, 3 \mathrm{H}, \mathrm{NCH}_{3}\right), 3.75-$ $3.66\left(\mathrm{~m}, 4 \mathrm{H}, \mathrm{N}\left(\mathrm{CH}_{2} \mathrm{C}_{2} \mathrm{Cl}\right)_{2}\right), 3.55-3.35\left(\mathrm{~m}, 8 \mathrm{H}, \mathrm{N}\left(\mathrm{C}_{2} \mathrm{CH}_{2} \mathrm{Cl}\right)_{2}, \mathrm{CH}_{2} \mathrm{CH}_{2} \mathrm{~N}^{+}\right), 3.22\left(\mathrm{~s}, 9 \mathrm{H}, \mathrm{N}^{+}\left(\mathrm{CH}_{3}\right)_{3}\right) ;{ }^{13} \mathrm{C}$ NMR (126 MHz, CD $\left.{ }_{3} \mathrm{OD}\right) \delta 147.73\left(\mathrm{C}_{\mathrm{Ar}} \mathrm{NO}_{2}\right), 134.64$ (d, $\left.{ }^{3} J_{\mathrm{C}-\mathrm{P}}=7.3 \mathrm{~Hz}, \underline{\mathrm{C}}_{\mathrm{Ar}} \mathrm{CH}_{2}\right), 129.37\left(\mathrm{CH}_{\mathrm{Ar}}\right), 67.47$ $\left(\mathrm{CH}_{2} \mathrm{~N}^{+}\right), 58.08\left(\mathrm{~d},{ }^{2} \mathrm{~J}_{\mathrm{C}-\mathrm{P}}=4.7 \mathrm{~Hz}, \mathrm{OCH}_{2}\right), 54.35,54.38,54.41\left(\mathrm{~N}^{+}\left(\mathrm{CH}_{3}\right)_{3}\right), 50.23\left(\mathrm{~d}, 2 \mathrm{C}^{2} \mathrm{~J}_{\mathrm{C}-\mathrm{P}}=4.7 \mathrm{~Hz}\right.$, $\left.\mathrm{N}\left(\mathrm{CH}_{2} \mathrm{CH}_{2} \mathrm{Cl}\right)_{2}\right), 43.23\left(2 \mathrm{C}, \mathrm{N}\left(\mathrm{CH}_{2} \underline{\mathrm{CH}}_{2} \mathrm{Cl}\right)_{2}\right), 41.05\left(\mathrm{CH}_{2} \mathrm{NHP}\right), 35.25\left(\mathrm{NCH}_{3}\right), 29.41\left(\mathrm{~d},{ }^{3} \mathrm{~J}_{\mathrm{C}-\mathrm{P}}=4.6 \mathrm{~Hz}\right.$, 
$\underline{\mathrm{CH}}_{2} \mathrm{CH}_{2} \mathrm{NHP}$ ), $21.36\left(\mathrm{CH}_{2} \mathrm{CH}_{2} \mathrm{~N}^{+}\right)$; ${ }^{31} \mathrm{P}$ NMR (202 MHz, CD 3 OD) $\delta$ 17.72; HRMS (ESI) m/z 445.1279 $[\mathrm{M}]^{+}$(calculated for $\left[\mathrm{C}_{14} \mathrm{H}_{28} \mathrm{Cl}_{2} \mathrm{~N}_{6} \mathrm{O}_{4} \mathrm{P}\right]^{+}$445.1281).

4.1.4.4.

5-(\{[bis(2-chloroethyl)amino][(1-methyl-2-nitro-1H-imidazol-5yl)methoxy]phosphoryl\}amino)-N-ethyl-N,N-dimethylpentane-1-aminium iodide (28d)

Alkylation of amine 23c (38 mg, $81.5 \mu \mathrm{mol}$ ) with ethyl iodide (12 eq. initially followed by 12 eq after $24 \mathrm{~h}$ ) using the standard procedure (reaction time: 36 h) afforded compound 28d analytically pure, as a yellow hygroscopic solid (36 mg, $56.7 \mu \mathrm{mol}$ ). Yield 70\%; IR (ATR) v cm ${ }^{-1}$ 3420, 3235, 1537, 1489, 1350, 1216, 1190, 1007, 976, 960, 835, 770, 744; ${ }^{1}$ H NMR (500 MHz, $\left.\mathrm{CD}_{3} \mathrm{OD}\right) \delta 7.25\left(\mathrm{~s}, 1 \mathrm{H}, \mathrm{CH}_{\mathrm{Ar}}\right), 5.16\left(\mathrm{dd}, 1 \mathrm{H},{ }^{2} \mathrm{~J}_{\mathrm{H}-\mathrm{H}}=13.5 \mathrm{~Hz},{ }^{3} \mathrm{~J}_{\mathrm{H}-\mathrm{P}}=8.3 \mathrm{~Hz}, \mathrm{OCH}^{\prime}\right), 5.12\left(\mathrm{dd}, 1 \mathrm{H},{ }^{2} J_{\mathrm{H}-\mathrm{H}}=\right.$ $\left.13.5 \mathrm{~Hz},{ }^{3} \mathrm{~J}_{\mathrm{H}-\mathrm{P}}=8.7 \mathrm{~Hz}, \mathrm{OCH}^{\prime \prime}\right), 4.08\left(\mathrm{~s}, 3 \mathrm{H}, \mathrm{NCH}_{3}\right), 3.71-3.62\left(\mathrm{~m}, 4 \mathrm{H}, \mathrm{N}\left(\mathrm{CH}_{2} \mathrm{C}_{2} \mathrm{Cl}_{2}\right)\right.$, 3.51-3.33 (m, $\left.6 \mathrm{H}, \mathrm{N}\left(\mathrm{C}_{2} \mathrm{CH}_{2} \mathrm{Cl}\right)_{2}, \mathrm{C}_{2} \mathrm{CH}_{3}\right), 3.34-3.28\left(\mathrm{~m}, 2 \mathrm{H}, \underline{\mathrm{C}}_{2} \mathrm{~N}^{+}\left(\mathrm{CH}_{3}\right)_{2} \mathrm{CH}_{2} \mathrm{CH}_{3}\right), 3.08\left(\mathrm{~s}, 6 \mathrm{H}, \mathrm{N}^{+}\left(\mathrm{CH}_{3}\right)_{2}\right)$, 2.982.85 (m, 2H, $\left.\underline{\mathrm{H}}_{2} \mathrm{NHP}\right), 1.83-1.72\left(\mathrm{~m}, 2 \mathrm{H}, \underline{\mathrm{CH}}_{2} \mathrm{CH}_{2} \mathrm{~N}^{+}\right), 1.59$ (qt, $\left.2 \mathrm{H},{ }^{3} \mathrm{~J}_{\mathrm{H}-\mathrm{H}}=7.0 \mathrm{~Hz}, \mathrm{CH}_{2} \mathrm{CH}_{2} \mathrm{NHP}\right), 1.46-$ 1.34 (m, 5H, CH $\left.\mathrm{C}_{3}, \mathrm{C}_{2} \mathrm{CH}_{2} \mathrm{CH}_{2} \mathrm{NHP}\right) ;{ }^{13} \mathrm{C}$ NMR (126 MHz, CD 30 D) $\delta 147.64\left(\mathrm{C}_{\mathrm{ArNO}_{2}}\right.$ ), 135.11 (d,

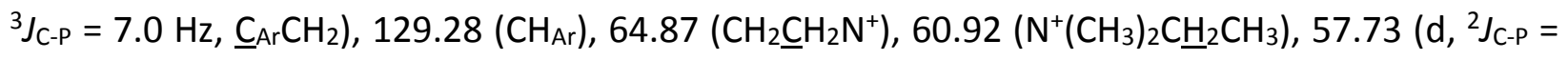
$\left.4.6 \mathrm{~Hz}, \mathrm{OCH}_{2}\right), 50.80\left(2 \mathrm{C}, \mathrm{N}^{+}\left(\mathrm{CH}_{3}\right)_{2}\right), 50.31$ (d, 2C, $\left.{ }^{2} \mathrm{~J}_{\mathrm{C}-\mathrm{p}}=4.6 \mathrm{~Hz}, \mathrm{~N}\left(\mathrm{CH}_{2} \mathrm{CH}_{2} \mathrm{Cl}\right)_{2}\right), 43.25(2 \mathrm{C}$, $\left.\mathrm{N}\left(\mathrm{CH}_{2} \mathrm{CH}_{2} \mathrm{Cl}\right)_{2}\right), 41.39\left(\mathrm{CH}_{2} \mathrm{NHP}\right), 35.24\left(\mathrm{NCH}_{3}\right), 32.20\left(\mathrm{~d},{ }^{3} \mathrm{~J}_{\mathrm{C}-\mathrm{P}}=5.4 \mathrm{~Hz}, \mathrm{CH}_{2} \mathrm{CH}_{2} \mathrm{NHP}\right), 24.45$ $\left(\underline{\mathrm{CH}_{2}} \mathrm{CH}_{2} \mathrm{CH}_{2} \mathrm{NHP}\right), 23.17\left(\underline{\mathrm{CH}}_{2} \mathrm{CH}_{2} \mathrm{~N}^{+}\right), 8.51\left(\mathrm{CH}_{2} \underline{\mathrm{CH}}_{3}\right)$; ${ }^{31} \mathrm{P}$ NMR (202 MHz, CD $\left.\mathrm{CD}_{3} \mathrm{O}\right)$ 18.26; HRMS (ESI) $\mathrm{m} / \mathrm{z} 501.1908[\mathrm{M}]^{+}$(calculated for $\left[\mathrm{C}_{18} \mathrm{H}_{36} \mathrm{Cl}_{2} \mathrm{~N}_{6} \mathrm{O}_{4} \mathrm{P}\right]^{+}$501.1907).

4.1.4.5.

4-(\{[bis(2-chloroethyl)amino][(1-methyl-2-nitro-1H-imidazol-5yl)methoxy]phosphoryl\}amino)-N-ethyl-N,N-dimethylbutane-1-aminium iodide (28e)

Alkylation of amine 23b (107 mg, $233 \mu \mathrm{mol}$ ) with ethyl iodide (12 eq.) using the standard procedure (reaction time: $4 \mathrm{~h}$ ) and purification by preparative high performance liquid chromatography (gradient ACN in water) afforded compound 28e as a hygroscopic lyophilisate

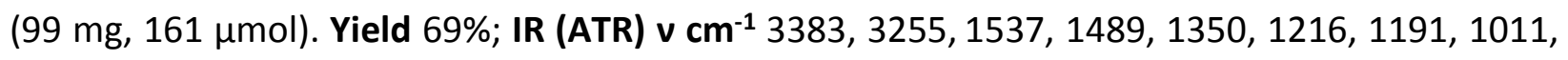
980, 960, 835, 744; ${ }^{1} \mathrm{H}$ NMR (500 MHz, CD $30 D$ ) $\delta 7.26\left(s, 1 \mathrm{H}, \mathrm{CH}_{\mathrm{Ar}}\right.$ ), 5.16 (dd, $1 \mathrm{H},{ }^{2} \mathrm{~J}_{\mathrm{H}-\mathrm{H}}=13.4 \mathrm{~Hz}$, $\left.{ }^{3} J_{\mathrm{H}-\mathrm{P}}=8.3 \mathrm{~Hz}, \mathrm{OCH}^{\prime}\right), 5.12\left(\mathrm{dd}, 1 \mathrm{H},{ }^{2} J_{\mathrm{H}-\mathrm{H}}=13.4 \mathrm{~Hz},{ }^{3} J_{\mathrm{H}-\mathrm{P}}=8.5 \mathrm{~Hz}, \mathrm{OCH}^{\prime \prime}\right), 4.07\left(\mathrm{~s}, 3 \mathrm{H}, \mathrm{NCH}_{3}\right), 3.72-$ $\left.3.63\left(\mathrm{~m}, 4 \mathrm{H}, \mathrm{N}\left(\mathrm{CH}_{2} \underline{\mathrm{C}}_{2} \mathrm{Cl}\right)_{2}\right), 3.52-3.35\left(\mathrm{~m}, 6 \mathrm{H}, \mathrm{N}\left(\mathrm{C}_{2} \mathrm{CH}_{2} \mathrm{Cl}\right)_{2}\right), \mathrm{C}_{2} \mathrm{CH}_{3}\right), 3.34-3.29(\mathrm{~m}, 2 \mathrm{H}$, 
$\left.\mathrm{C}_{2} \mathrm{~N}^{+}\left(\mathrm{CH}_{3}\right)_{2} \mathrm{CH}_{2} \mathrm{CH}_{3}\right), 3.07\left(\mathrm{~s}, 6 \mathrm{H}, \mathrm{N}^{+}\left(\mathrm{CH}_{3}\right)_{2}\right), 2.95\left(\mathrm{td}, 2 \mathrm{H},{ }^{3} \mathrm{~J}_{\mathrm{H}-\mathrm{P}}=11.4 \mathrm{~Hz},{ }^{3} \int_{\mathrm{H}-\mathrm{P}}=6.8 \mathrm{~Hz}, \mathrm{CH}_{2} \mathrm{NHP}\right)$, 1.85-1.76 (m, 2H, $\left.\underline{\mathrm{C}}_{2} \mathrm{CH}_{2} \mathrm{~N}^{+}\right), 1.56\left(\mathrm{qt}, 2 \mathrm{H},{ }^{3} \mathrm{~J}_{\mathrm{H}-\mathrm{H}}=7.0 \mathrm{~Hz}, \mathrm{C}_{2} \mathrm{CH}_{2} \mathrm{NHP}\right), 1.40-1.35\left(\mathrm{~m}, 3 \mathrm{H}, \mathrm{CH}_{2} \mathrm{C}_{3}\right)$; ${ }^{13} \mathrm{C}$ NMR (126 MHz, CD $\left.{ }_{3} \mathrm{OD}\right) \delta 147.65\left(\mathrm{C}_{\mathrm{ArNO}}\right), 135.00\left(\mathrm{~d},{ }^{3} \mathrm{~J}_{\mathrm{C}-\mathrm{P}}=7.1 \mathrm{~Hz}, \underline{\mathrm{C}}_{\mathrm{Ar}} \mathrm{CH}_{2}\right), 129.19\left(\mathrm{CH}_{\mathrm{Ar}}\right)$, $64.46\left(\mathrm{CH}_{2} \mathrm{~N}^{+}\right), 60.88\left(\mathrm{CH}_{2} \mathrm{CH}_{3}\right), 57.72\left(\mathrm{~d},{ }^{2}{ }_{\mathrm{C}-\mathrm{P}}=4.7 \mathrm{~Hz}, \mathrm{OCH}_{2}\right), 50.72\left(2 \mathrm{C}, \mathrm{N}^{+}\left(\mathrm{CH}_{3}\right)_{2}\right), 50.17(\mathrm{~d}, 2 \mathrm{C}$, $\left.{ }^{2} J_{\mathrm{C}-\mathrm{P}}=4.7 \mathrm{~Hz}, \mathrm{~N}\left(\underline{\mathrm{CH}}_{2} \mathrm{CH}_{2} \mathrm{Cl}\right)_{2}\right), 43.17\left(2 \mathrm{C}, \mathrm{N}\left(\mathrm{CH}_{2} \mathrm{CH}_{2} \mathrm{Cl}\right)_{2}\right), 41.06\left(\mathrm{CH}_{2} \mathrm{NHP}\right), 35.21\left(\mathrm{NCH}_{3}\right), 29.50$ (d, $\left.{ }^{3} J_{\mathrm{C}-\mathrm{P}}=5.0 \mathrm{~Hz}, \underline{\mathrm{CH}}{ }_{2} \mathrm{CH}_{2} \mathrm{NHP}\right), 20.90\left(\underline{\mathrm{CH}}_{2} \mathrm{CH}_{2} \mathrm{CH}_{2} \mathrm{NHP}\right), 8.46\left(\mathrm{CH}_{2} \underline{\mathrm{CH}}_{3}\right) ;{ }^{31} \mathrm{P}$ NMR (202 MHz, CD $\left.\mathrm{OD}\right) \delta$ 18.25; HRMS (ESI) m/z 487.1747 [M] $]^{+}$calculated for $\left[\mathrm{C}_{17} \mathrm{H}_{34} \mathrm{Cl}_{2} \mathrm{~N}_{6} \mathrm{O}_{4} \mathrm{P}\right]^{+} 487.1751$ ).

4.1.4.6.

3-(\{[bis(2-chloroethyl)amino][(1-methyl-2-nitro-1H-imidazol-5yl)methoxy]phosphoryl\}amino)-N-ethyl-N,N-dimethylpropane-1-aminium iodide (28f)

Alkylation of amine $23 \mathrm{c}$ (55 mg, $123 \mu \mathrm{mol}$ ) with ethyl iodide ( 24 eq.) using the standard procedure (reaction time: $24 \mathrm{~h}$ ) afforded compound $\mathbf{2 8 f}$ analytically pure, as a yellow hygroscopic solid (68.0

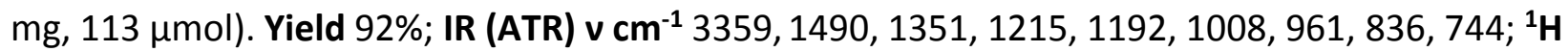
NMR (500 MHz, CD $30 D$ ) $\delta 7.28\left(\mathrm{~s}, 1 \mathrm{H}, \mathrm{CH}_{\mathrm{Ar}}\right), 5.20\left(\mathrm{dd}, 1 \mathrm{H},{ }^{2} \mathrm{~J}_{\mathrm{H}-\mathrm{H}}=13.5 \mathrm{~Hz},{ }^{3} \mathrm{~J}_{\mathrm{H}-\mathrm{P}}=8.6 \mathrm{~Hz}, \mathrm{OCH}^{\prime}\right)$, $5.15\left(\mathrm{dd}, 1 \mathrm{H},{ }^{2} \mathrm{~J}_{\mathrm{H}-\mathrm{H}}=13.5 \mathrm{~Hz},{ }^{3} \mathrm{~J}_{\mathrm{H}-\mathrm{P}}=8.6 \mathrm{~Hz}, \mathrm{OCH}^{\prime \prime}\right), 4.08\left(\mathrm{~s}, 3 \mathrm{H}, \mathrm{NCH}_{3}\right), 3.74-3.64(\mathrm{~m}, 4 \mathrm{H}$, $\left.\left.\mathrm{N}\left(\mathrm{CH}_{2} \mathrm{C}_{2} \mathrm{Cl}\right)_{2}\right), 3.53-3.36\left(\mathrm{~m}, 8 \mathrm{H}, \mathrm{N}\left(\mathrm{C}_{2} \mathrm{CH}_{2} \mathrm{Cl}\right)_{2}\right), \underline{\mathrm{C}}_{2} \mathrm{~N}^{+}\left(\mathrm{CH}_{3}\right)_{2} \mathrm{C}_{2} \mathrm{CH}_{3}\right), 3.10\left(\mathrm{~s}, 6 \mathrm{H}, \mathrm{N}^{+}\left(\underline{\mathrm{C}}_{3}\right)_{2}\right), 3.02$ $\left(\mathrm{td}, 2 \mathrm{H},{ }^{3} J_{\mathrm{H}-\mathrm{P}}=12.4 \mathrm{~Hz},{ }^{3} \mathrm{~J}_{\mathrm{H}-\mathrm{P}}=6.4 \mathrm{~Hz}, \underline{\mathrm{C}}_{2} \mathrm{NHP}\right), 2.05-1.94\left(\mathrm{~m}, 2 \mathrm{H}, \mathrm{CH}_{2} \mathrm{C}_{2} \mathrm{CH}_{2}\right), 1.46-1.34(\mathrm{~m}, 3 \mathrm{H}$, $\left.\mathrm{CH}_{2} \underline{\mathrm{C}}_{3}\right) ;{ }^{13} \mathrm{C}$ NMR (126 MHz, CD $\left.{ }_{3} \mathrm{OD}\right) \delta 147.66\left(\mathrm{C}_{\mathrm{ArNO}}\right), 134.99$ (d, $\left.{ }^{3} \mathrm{~J}_{\mathrm{C}-\mathrm{p}}=7.3 \mathrm{~Hz}, \underline{\mathrm{C}}_{\mathrm{Ar}} \mathrm{CH}_{2}\right), 129.34$ $\left(\mathrm{CH}_{\mathrm{Ar}}\right), 62.83\left(\mathrm{CH}_{2} \underline{\mathrm{CH}}_{2} \mathrm{~N}^{+}\right), 61.15\left(\underline{\mathrm{CH}}_{2} \mathrm{CH}_{3}\right), 57.93\left(\mathrm{~d},{ }^{2} \mathrm{~J} \mathrm{C}-\mathrm{P}=4.7 \mathrm{~Hz}, \mathrm{OCH}_{2}\right), 51.03\left(2 \mathrm{C}, \mathrm{N}^{+}\left(\mathrm{CH}_{3}\right)_{2}\right)$, $50.11\left(\mathrm{~d}, 2 \mathrm{C},{ }^{2} \mathrm{~J}_{\mathrm{C}-\mathrm{P}}=4.6 \mathrm{~Hz}, \mathrm{~N}\left(\underline{\mathrm{CH}}_{2} \mathrm{CH}_{2} \mathrm{Cl}\right)_{2}\right), 43.24\left(2 \mathrm{C}, \mathrm{N}\left(\mathrm{CH}_{2} \underline{\mathrm{CH}}_{2} \mathrm{Cl}\right)_{2}\right), 38.83\left(\mathrm{CH}_{2} \mathrm{NHP}\right), 35.36\left(\mathrm{NCH}_{3}\right)$, $25.89\left(\mathrm{~d},{ }^{3} \mathrm{~J}_{\mathrm{C}-\mathrm{P}}=4.8 \mathrm{~Hz}, \mathrm{CH}_{2} \underline{\mathrm{CH}}_{2} \mathrm{CH}_{2}\right), 8.58\left(\mathrm{CH}_{2} \mathrm{CH}_{3}\right) ;{ }^{31} \mathrm{P}$ NMR (202 MHz, CD $\mathrm{CDD}_{3} \delta$ (ppm) 17.26; HRMS (ESI) m/z $473.1595[\mathrm{M}]^{+}$(calculated for $\left[\mathrm{C}_{16} \mathrm{H}_{32} \mathrm{Cl}_{2} \mathrm{~N}_{6} \mathrm{O}_{4} \mathrm{P}\right]^{+} 473.1594$ ).

4.1.4.7. 2-(\{[bis(2-chloroethyl)amino][(1-methyl-2-nitro-1H-imidazol-5yl)methoxy]phosphoryl\}amino)-N-ethyl-N,N-dimethylethane-1-aminium iodide (28g)

Alkylation of amine 23d (114 mg, $0.264 \mathrm{mmol}$ ) with ethyl iodide (12 eq.) using the standard procedure (reaction time: $24 \mathrm{~h}$ ) and purification by preparative high performance liquid chromatography (gradient ACN in water) afforded compound $\mathbf{2 8 g}$ as a hygroscopic lyophilisate

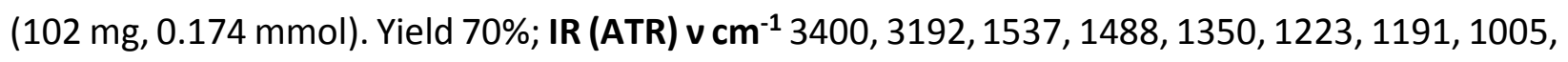


974, 959, 835, 744; ${ }^{1} \mathrm{H}$ NMR (500 MHz, CD $30 D$ ) $\delta 7.28\left(\mathrm{~s}, 1 \mathrm{H}, \mathrm{CH}_{\mathrm{Ar}}\right.$ ), $5.20\left(\mathrm{dd}, 2 \mathrm{H},{ }^{2} \mathrm{~J}_{\mathrm{H}-\mathrm{H}}=13.4 \mathrm{~Hz}\right.$, $\left.{ }^{3} J_{\mathrm{H}-\mathrm{P}}=8.4 \mathrm{~Hz}, \mathrm{CH}^{\prime} \mathrm{O}\right), 5.17\left(\mathrm{dd}, 2 \mathrm{H},{ }^{2} \mathrm{~J}_{\mathrm{H}-\mathrm{H}}=13.4 \mathrm{~Hz},{ }^{3} \mathrm{~J}_{\mathrm{H}-\mathrm{H}}=8.4 \mathrm{~Hz}, \mathrm{CH}^{\prime \prime} \mathrm{O}\right), 4.08\left(\mathrm{~s}, 3 \mathrm{H}, \mathrm{NCH}_{3}\right), 3.74-$ $3.68\left(\mathrm{~m}, 4 \mathrm{H}, \mathrm{N}\left(\mathrm{CH}_{2} \mathrm{C}_{2} \mathrm{Cl}\right)_{2}\right), 3.53-3.33\left(\mathrm{~m}, 10 \mathrm{H}, \mathrm{N}\left(\mathrm{C}_{2} \mathrm{CH}_{2} \mathrm{Cl}\right)_{2}, \mathrm{CH}_{2} \mathrm{CH}_{2} \mathrm{~N}^{+} \mathrm{CH}_{2}\right), 3.14(\mathrm{~s}, 6 \mathrm{H}$, $\left.\mathrm{N}^{+}\left(\mathrm{CH}_{3}\right)_{2}\right), 1.42-1.36\left(\mathrm{~m}, 3 \mathrm{H}, \mathrm{CH}_{2} \mathrm{C}_{3}\right) ;{ }^{13} \mathrm{C} \mathrm{NMR}\left(126 \mathrm{MHz}, \mathrm{CD}_{3} \mathrm{OD}\right) \delta 147.73\left(\mathrm{C}_{\mathrm{ArNO}} \mathrm{NO}_{2}\right), 134.66$ (d, $\left.{ }^{3} J_{\mathrm{C}-\mathrm{P}}=7.2 \mathrm{~Hz}, \underline{\mathrm{C}}_{\mathrm{Ar}} \mathrm{CH}_{2}\right), 129.39\left(\mathrm{CH}_{\mathrm{Ar}}\right), 64.36\left(\mathrm{CH}_{2} \underline{\mathrm{CH}}_{2} \mathrm{~N}^{+}\right), 61.65\left(\underline{\mathrm{CH}}_{2} \mathrm{CH}_{3}\right), 58.10\left(\mathrm{~d},{ }^{2} \mathrm{~J}_{\mathrm{C}-\mathrm{P}}=4.9 \mathrm{~Hz}\right.$, $\left.\mathrm{OCH}_{2}\right), 51.46,51.44\left(\mathrm{~N}^{+}\left(\mathrm{CH}_{3}\right)_{2}\right), 49.95\left(\mathrm{~d}, 2 \mathrm{C},{ }^{2} \mathrm{~J}_{\mathrm{C}-\mathrm{P}}=4.8 \mathrm{~Hz}, \mathrm{~N}\left(\mathrm{CH}_{2} \mathrm{CH}_{2} \mathrm{Cl}\right)_{2}\right), 43.15$ (2C, $\left.\mathrm{N}\left(\mathrm{CH}_{2} \underline{\mathrm{CH}}_{2} \mathrm{Cl}\right)_{2}\right), 35.74\left(\mathrm{CH}_{2} \mathrm{NHP}\right), 35.29\left(\mathrm{NCH}_{3}\right), 8.53\left(\mathrm{CH}_{2} \underline{\mathrm{CH}}_{3}\right) ;{ }^{31} \mathrm{P}$ NMR (202 MHz, CD $\left.3 \mathrm{OD}\right)$ ठ 17.73; HRMS (ESI) m/z $459.1427[\mathrm{M}]^{+}$(calculated for $\left[\mathrm{C}_{15} \mathrm{H}_{30} \mathrm{Cl}_{2} \mathrm{~N}_{6} \mathrm{O}_{4} \mathrm{P}\right]^{+} 459.1438$ ).

4.1.4.8.

5-(\{[bis(2-chloroethyl)amino][(1-methyl-2-nitro-1H-imidazol-5yl)methoxy]phosphoryl\}amino)-N,N-diethyl- $N$-methylpentane-1-aminium iodide (29a)

Alkylation of amine 24a (148 mg, $295 \mu \mathrm{mol}$ ) with methyl iodide (12 eq.) using the standard procedure (reaction time: $12 \mathrm{~h}$ ) afforded compound 29a analytically pure, as a yellow hygroscopic

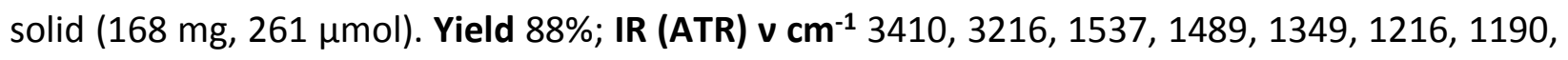
1008, 978, 959, 834, 769, 743; ${ }^{1} \mathrm{H}$ NMR (500 MHz, CD $\left.{ }_{3} \mathrm{OD}\right) \delta 7.25\left(\mathrm{~s}, 1 \mathrm{H}, \mathrm{CH}_{\mathrm{Ar}}\right), 5.16\left(\mathrm{dd}, 1 \mathrm{H},{ }^{2} J_{\mathrm{H}-\mathrm{H}}\right.$ $\left.=13.4 \mathrm{~Hz},{ }^{3} J_{\mathrm{H}-\mathrm{P}}=8.3 \mathrm{~Hz}, \mathrm{CH}^{\prime} \mathrm{O}\right), 5.12\left(\mathrm{dd}, 1 \mathrm{H},{ }^{2} \mathrm{~J}_{\mathrm{H}-\mathrm{H}}=13.4 \mathrm{~Hz},{ }^{3} \mathrm{~J}_{\mathrm{H}-\mathrm{P}}=8.7 \mathrm{~Hz}, \mathrm{CH}^{\prime \prime} \mathrm{O}\right), 4.08\left(\mathrm{~s}, 3 \mathrm{H}, \mathrm{NCH}_{3}\right)$, 3.71-3.62 (m, $\left.4 \mathrm{H}, \mathrm{N}\left(\mathrm{CH}_{2} \mathrm{C}_{2} \mathrm{Cl}\right)_{2}\right), 3.50-3.35\left(\mathrm{~m}, 5 \mathrm{H}, \mathrm{N}\left(\mathrm{C}_{2} \mathrm{CH}_{2} \mathrm{Cl}\right)_{2}, \mathrm{NHP}\right), 3.39\left(\mathrm{q}, 4 \mathrm{H},{ }^{3} \mathrm{H}_{\mathrm{H}-\mathrm{H}}=7.3 \mathrm{~Hz}\right.$, $\left.\mathrm{N}^{+}\left(\underline{\mathrm{C}}_{2} \mathrm{CH}_{3}\right)_{2}\right), 3.30-3.24\left(\mathrm{~m}, 2 \mathrm{H}, \mathrm{CH}_{2} \mathrm{C}_{2} \mathrm{~N}^{+}\right), 3.00\left(\mathrm{~s}, 3 \mathrm{H}, \mathrm{N}^{+} \underline{\mathrm{C}}_{3}\right), 2.91$ (tdd, $2 \mathrm{H},{ }^{3} \mathrm{H}_{\mathrm{H}-\mathrm{P}}=11.2 \mathrm{~Hz}, 3^{3} \mathrm{H}^{-}$ $\left.\mathrm{H}=6.8 \mathrm{~Hz},{ }^{3} \mathrm{~J}_{\mathrm{H}-\mathrm{H}}=1.5 \mathrm{~Hz}, \underline{\mathrm{H}}_{2} \mathrm{NHP}\right), 1.80-1.70\left(\mathrm{~m}, 2 \mathrm{H}, \mathrm{C}_{2} \mathrm{CH}_{2} \mathrm{~N}^{+}\right), 1.59\left(q \mathrm{t}, 2 \mathrm{H},{ }^{3} \mathrm{~J}_{\mathrm{H}-\mathrm{H}}=7.2 \mathrm{~Hz}\right.$, $\left.\mathrm{C}_{2}{ }_{2} \mathrm{CH}_{2} \mathrm{NHP}\right), 1.47-1.38\left(\mathrm{~m}, 8 \mathrm{H}, \mathrm{C}_{2} \mathrm{CH}_{2} \mathrm{CH}_{2} \mathrm{NHP}\right), 1.38-1.32\left(\mathrm{~m}, 6 \mathrm{H}, \mathrm{N}^{+}\left(\mathrm{CH}_{2} \mathrm{C}_{3}\right)_{2}\right) ;{ }^{13} \mathrm{C}$ NMR (126 $\left.\mathrm{MHz}, \mathrm{CD}_{3} \mathrm{OD}\right) \delta 147.65\left(\mathrm{C}_{\mathrm{ArNO}} \mathrm{NO}_{2}\right), 135.11\left(\mathrm{~d},{ }^{3} \mathrm{~J}-\mathrm{P}=7.0 \mathrm{~Hz}, \underline{\mathrm{C}}_{\mathrm{Ar}} \mathrm{CH}_{2}\right), 129.28\left(\mathrm{CH}_{\mathrm{Ar}}\right), 61.78\left(\mathrm{CH}_{2} \underline{\mathrm{C}}_{2} \mathrm{~N}^{+}\right)$, $57.67\left(2 \mathrm{C}, \mathrm{N}^{+}\left(\underline{\mathrm{C}}_{2} \mathrm{CH}_{3}\right)_{2}\right), 57.72\left(\mathrm{~d},{ }^{2} \mathrm{~J}_{\mathrm{C}-\mathrm{P}}=5.0 \mathrm{~Hz}, \mathrm{OCH}_{2}\right), 50.31\left(\mathrm{~d}, 2 \mathrm{C},{ }^{2} \mathrm{~J}_{\mathrm{C}-\mathrm{P}}=4.7 \mathrm{~Hz}, \mathrm{~N}\left(\underline{\mathrm{CH}}_{2} \mathrm{CH}_{2} \mathrm{Cl}\right)_{2}\right)$, $47.83\left(\mathrm{~N}^{+} \mathrm{CH}_{3}\right), 43.25\left(2 \mathrm{C}, \mathrm{N}\left(\mathrm{CH}_{2} \underline{\mathrm{CH}}_{2} \mathrm{Cl}\right)_{2}\right), 41.40\left(\mathrm{C}_{2} \mathrm{NHP}\right), 35.25\left(\mathrm{NCH}_{3}\right), 32.21\left(\mathrm{~d},{ }^{3} \mathrm{C}-\mathrm{P}=5.5 \mathrm{~Hz}\right.$, $\left.\underline{\mathrm{CH}}_{2} \mathrm{CH}_{2} \mathrm{NHP}\right), 24.51\left(\mathrm{C}_{2} \mathrm{CH}_{2} \mathrm{CH}_{2} \mathrm{NHP}\right), 22.80\left(\underline{\mathrm{CH}}_{2} \mathrm{CH}_{2} \mathrm{~N}^{+}\right), 8.18\left(2 \mathrm{C}, \mathrm{N}^{+}\left(\mathrm{CH}_{2} \underline{\mathrm{CH}}_{3}\right)_{2}\right) ;$ HRMS (ESI) m/z 515.2073 [M] $]^{+}$(calculated for $\left[\mathrm{C}_{19} \mathrm{H}_{38} \mathrm{Cl}_{2} \mathrm{~N}_{6} \mathrm{O}_{4} \mathrm{P}\right]^{+}$515.2064).

4.1.4.9.

4-(\{[bis(2-chloroethyl)amino][(1-methyl-2-nitro-1H-imidazol-5yl)methoxy]phosphoryl\}amino)-N,N-diethyl-N-methylbutane-1-aminium iodide (29b) 
Alkylation of amine $24 \mathrm{~b}$ ( $27 \mathrm{mg}, 55.4 \mu \mathrm{mol}$ ) with methyl iodide (12 eq.) using the standard procedure (reaction time: $24 \mathrm{~h}$ ) afforded compound 29b analytically pure, as a yellow hygroscopic solid (30 mg, $47.7 \mu \mathrm{mol}$ ). Yield 86\%; IR (ATR) v cm $\mathbf{c m}^{-1}$ 3419, 3208, 1537, 1490, 1350, 1217, 1191, 1012, 836, 744; ${ }^{1} \mathrm{H}$ NMR (500 MHz, CD $\left.30 D\right) \delta 7.25\left(\mathrm{~s}, 1 \mathrm{H}, \mathrm{CH}_{\mathrm{Ar}}\right), 5.16\left(\mathrm{dd}, 1 \mathrm{H},{ }^{2} J_{\mathrm{H}-\mathrm{H}}=\right.$ $\left.13.3 \mathrm{~Hz},{ }^{3} \mathrm{~J}_{\mathrm{H}-\mathrm{P}}=8.3 \mathrm{~Hz}, \mathrm{CH}^{\prime} \mathrm{O}\right), 5.12\left(\mathrm{dd}, 1 \mathrm{H},{ }^{2} \mathrm{~J}_{\mathrm{H}-\mathrm{H}}=13.3 \mathrm{~Hz},{ }^{3} \mathrm{~J}_{\mathrm{H}-\mathrm{P}}=8.6 \mathrm{~Hz}, \mathrm{CH}^{\prime \prime} \mathrm{O}\right), 4.07\left(\mathrm{~s}, 3 \mathrm{H}, \mathrm{NCH}_{3}\right)$, $3.68\left(\mathrm{td}, 4 \mathrm{H},{ }^{3} \mathrm{~J}_{\mathrm{H}-\mathrm{H}}=7.1 \mathrm{~Hz},{ }^{4} J_{\mathrm{H}-\mathrm{P}}=2.7 \mathrm{~Hz}, \mathrm{~N}\left(\mathrm{CH}_{2} \mathrm{C}_{2} \mathrm{Cl}\right)_{2}\right), 3.51-3.33\left(\mathrm{~m}, 8 \mathrm{H}, \mathrm{N}\left(\mathrm{C}_{2} \mathrm{CH}_{2} \mathrm{Cl}\right)_{2}\right.$, $\left.\mathrm{N}^{+}\left(\mathrm{C}_{2} \mathrm{CH}_{3}\right)_{2}\right), 3.29-3.22\left(\mathrm{~m}, 2 \mathrm{H}, \mathrm{CH}_{2} \mathrm{C}_{2} \mathrm{~N}^{+}\right), 3.00\left(\mathrm{~s}, 3 \mathrm{H}, \mathrm{N}^{+} \mathrm{C}_{3}\right), 2.94\left(\mathrm{td}, 2 \mathrm{H}, 3^{3} \mathrm{H}_{-\mathrm{H}}=6.8 \mathrm{~Hz},{ }^{3} \mathrm{~J}_{\mathrm{H}-\mathrm{P}}=\right.$ $11.6 \mathrm{~Hz}, \mathrm{CH}_{2} \mathrm{NHP}$ ), 1.82-1.71 (m, $2 \mathrm{H}, \mathrm{C}_{2} \mathrm{CH}_{2} \mathrm{~N}^{+}$), 1.55 (qt, $2 \mathrm{H},{ }^{3} \mathrm{~J}_{\mathrm{H}-\mathrm{H}}=7.8 \mathrm{~Hz}, \mathrm{C}_{2} \mathrm{CH}_{2} \mathrm{NHP}$ ), 1.34 (t, $\left.6 \mathrm{H},{ }^{3} J_{\mathrm{H}-\mathrm{H}}=7.2 \mathrm{~Hz}, \mathrm{~N}^{+}\left(\mathrm{CH}_{2} \mathrm{C}_{3}\right)_{2}\right) ;{ }^{13} \mathrm{C}$ NMR (126 MHz, CD $\left.3 \mathrm{OD}\right) \delta 147.67\left(\mathrm{C}_{\mathrm{ArNO}} \mathrm{NO}_{2}\right), 135.03\left(\mathrm{~d},{ }^{3} \mathrm{~J}_{\mathrm{C}-\mathrm{P}}=\right.$ $\left.7.2 \mathrm{~Hz}, \underline{\mathrm{C}}_{\mathrm{ArCH}} \mathrm{CH}_{2}\right), 129.25\left(\mathrm{CH}_{\mathrm{Ar}}\right), 61.53\left(\mathrm{CH}_{2} \mathrm{~N}^{+}\right), 57.76\left(\mathrm{~d},{ }^{2} \mathrm{~J}_{\mathrm{C}-\mathrm{P}}=4.9 \mathrm{~Hz}, \mathrm{OCH}_{2}\right), 57.70(2 \mathrm{C}$, $\left.\mathrm{N}^{+}\left(\underline{\mathrm{CH}}_{2} \mathrm{CH}_{3}\right)_{2}\right), 50.24\left(\mathrm{~d}, 2 \mathrm{C},{ }^{2} \mathrm{~J}-\mathrm{p}=4.7 \mathrm{~Hz}, \mathrm{~N}\left(\underline{\mathrm{CH}}_{2} \mathrm{CH}_{2} \mathrm{Cl}\right)_{2}\right), 47.81\left(\mathrm{~N}^{+} \mathrm{CH}_{3}\right), 43.22\left(2 \mathrm{C}, \mathrm{N}\left(\mathrm{CH}_{2} \underline{\mathrm{CH}}_{2} \mathrm{Cl}\right)_{2}\right)$, $41.12\left(\mathrm{CH}_{2} \mathrm{NHP}\right), 35.22\left(\mathrm{NCH}_{3}\right), 29.54\left(\mathrm{~d},{ }^{3} \mathrm{~J}_{\mathrm{C}-\mathrm{P}}=4.6 \mathrm{~Hz}, \mathrm{CH}_{2} \mathrm{CH}_{2} \mathrm{NHP}\right), 20.62\left(\underline{\mathrm{CH}}_{2} \mathrm{CH}_{2} \mathrm{~N}^{+}\right), 8.15(2 \mathrm{C}$, $\left.\mathrm{N}^{+}\left(\mathrm{CH}_{2} \mathrm{CH}_{3}\right)_{2}\right) ;{ }^{31} \mathrm{P}$ NMR (202 MHz, CD 30 O) $\delta$ 18.32; HRMS (ESI) m/z $501.1906[\mathrm{M}]^{+}$(calculated for $\left[\mathrm{C}_{18} \mathrm{H}_{36} \mathrm{Cl}_{2} \mathrm{~N}_{6} \mathrm{O}_{4} \mathrm{P}\right]^{+}$501.1907).

4.1.4.10. 5-(\{[bis(2-chloroethyl)amino][(1-methyl-2-nitro-1H-imidazol-5yl)methoxy]phosphoryl\}amino)-N,N-diethyl-N-methylpropane-1-aminium iodide (29c)

Alkylation of amine 24c (52 mg, 109 umol) with methyl iodide (6 eq.) using the standard procedure (reaction time: $4 \mathrm{~h}$ ) afforded compound 29c analytically pure, as a yellow hygroscopic

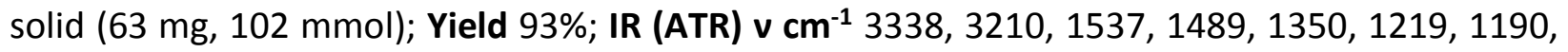
1008, 978, 960, 835, 745; ${ }^{1} \mathrm{H}$ NMR (500 MHz, CD $\left.30 D\right) \delta 7.28\left(\mathrm{~s}, 1 \mathrm{H}, \mathrm{CH}_{\mathrm{Ar}}\right), 5.19\left(\mathrm{dd}, 1 \mathrm{H},{ }^{2} J_{\mathrm{H}-\mathrm{H}}=\right.$ $\left.13.4 \mathrm{~Hz},{ }^{3} \mathrm{~J}_{\mathrm{H}-\mathrm{P}}=8.2 \mathrm{~Hz}, \mathrm{CH}^{\prime} \mathrm{O}\right), 5.15\left(\mathrm{dd}, 1 \mathrm{H},{ }^{2} \mathrm{~J}_{\mathrm{H}-\mathrm{H}}=13.4 \mathrm{~Hz},{ }^{3} J_{\mathrm{H}-\mathrm{P}}=8.4 \mathrm{~Hz}, \mathrm{CH}^{\prime \prime} \mathrm{O}\right), 4.08\left(\mathrm{~s}, 3 \mathrm{H}, \mathrm{NCH}_{3}\right)$, 3.73-3.66 (m, 4H, N( $\left.\left.\mathrm{CH}_{2} \underline{\mathrm{C}}_{2} \mathrm{Cl}\right)_{2}\right)$, 3.50-3.35 (m, $\left.10 \mathrm{H}, \mathrm{N}\left(\mathrm{C}_{2} \mathrm{CH}_{2} \mathrm{Cl}\right)_{2}, \underline{\mathrm{C}}_{2} \mathrm{~N}^{+}\left(\mathrm{C}_{2} \mathrm{CH}_{3}\right)_{2}\right), 3.05-2.97$ (m, $\left.2 \mathrm{H}, \mathrm{CH}_{2} \mathrm{NHP}\right), 3.02\left(\mathrm{~s}, 3 \mathrm{H}, \mathrm{N}^{+} \underline{\mathrm{C}}_{3}\right), 2.00-1.90\left(\mathrm{~m}, 2 \mathrm{H}, \mathrm{CH}_{2} \underline{\mathrm{C}}_{2} \mathrm{CH}_{2}\right), 1.36\left(\mathrm{t}, 6 \mathrm{H},{ }^{3} \mathrm{H}-\mathrm{H}=7.2 \mathrm{~Hz}\right.$, $\left.\mathrm{N}^{+}\left(\mathrm{CH}_{2} \mathrm{C}_{3}\right)_{2}\right) ;{ }^{13} \mathrm{C}$ NMR (126 MHz, CD $\left.{ }_{3} \mathrm{OD}\right) \delta 147.65\left(\mathrm{C}_{\mathrm{ArNO}}\right), 134.94\left(\mathrm{~d},{ }^{3} \mathrm{~J}_{\mathrm{C}-\mathrm{P}}=7.3 \mathrm{~Hz}\right.$, $\left.\underline{\mathrm{C}}_{\mathrm{Ar}} \mathrm{CH}_{2}\right), 129.32\left(\mathrm{CH}_{\mathrm{Ar}}\right), 59.75\left(\mathrm{CH}_{2} \underline{\mathrm{CH}}_{2} \mathrm{~N}^{+}\right), 57.92\left(2 \mathrm{C}, \mathrm{N}^{+}\left(\underline{\mathrm{CH}}_{2} \mathrm{CH}_{3}\right)_{2}\right), 57.89\left(\mathrm{OCH}_{2}\right), 50.09\left(\mathrm{~d}, 2 \mathrm{C},{ }^{2} J_{\mathrm{C}}\right.$ $\left.\mathrm{p}=4.7 \mathrm{~Hz}, \mathrm{~N}\left(\mathrm{CH}_{2} \mathrm{CH}_{2} \mathrm{Cl}\right)_{2}\right), 47.99\left(\mathrm{~N}^{+} \mathrm{CH}_{3}\right), 43.22\left(2 \mathrm{C}, \mathrm{N}\left(\mathrm{CH}_{2} \mathrm{CH}_{2} \mathrm{Cl}\right)_{2}\right), 38.84\left(\mathrm{CH}_{2} \mathrm{NHP}\right), 35.32\left(\mathrm{NCH}_{3}\right)$, 
$25.51\left(\mathrm{~d},{ }^{3} \mathrm{~J}_{\mathrm{C}-\mathrm{P}}=5.0 \mathrm{~Hz}, \mathrm{CH}_{2} \underline{\mathrm{C}} \mathrm{H}_{2} \mathrm{CH}_{2}\right), 8.22\left(2 \mathrm{C}, \mathrm{N}^{+}\left(\mathrm{CH}_{2} \underline{\mathrm{CH}_{3}}\right)_{2}\right) ;{ }^{31} \mathrm{P}$ NMR (202 MHz, CD 3 OD) $\delta$ 18.03; HRMS (ESI) m/z $487.1750[\mathrm{M}]^{+}$(calculated for $\left[\mathrm{C}_{17} \mathrm{H}_{34} \mathrm{Cl}_{2} \mathrm{~N}_{6} \mathrm{O}_{4} \mathrm{P}\right]^{+} 487.1751$ ).

4.1.4.11.

2-(\{[bis(2-chloroethyl)amino][(1-methyl-2-nitro-1H-imidazol-5yl)methoxy]phosphoryl\}amino)-N,N-diethyl-N-methylethane-1-aminium iodide (29d)

Alkylation of amine $\mathbf{2 4 d}$ (100 mg, $218 \mu \mathrm{mol}$ ) with methyl iodide (12 eq.) using the standard procedure (reaction time: $25 \mathrm{~h}$ ) and purification by preparative high performance liquid chromatography (gradient ACN in water) afforded compound 29d as a hygroscopic lyophilisate (104 mg, 173 umol). Yield 79\%; IR (ATR) v cm-1 3433, 3195, 1537, 1489, 1350, 1223, 1190, 1006, 977, 960, 835, 772, 745; ${ }^{1} \mathrm{H}$ NMR (500 MHz, CD $30 D$ ) $\delta 7.29\left(\mathrm{~s}, 1 \mathrm{H}, \mathrm{CH}_{\mathrm{Ar}}\right.$ ), 5.20 (dd, $1 \mathrm{H},{ }^{2} \mathrm{~J}_{\mathrm{H}-\mathrm{H}}=13.4$ $\left.\mathrm{Hz},{ }^{3} \mathrm{~J}_{\mathrm{H}-\mathrm{P}}=8.4 \mathrm{~Hz}, \mathrm{CH}^{\prime} \mathrm{O}\right), 5.17\left(\mathrm{dd}, 1 \mathrm{H},{ }^{2} \mathrm{~J}_{\mathrm{H}-\mathrm{H}}=13.4 \mathrm{~Hz},{ }^{3} \mathrm{~J}_{\mathrm{H}-\mathrm{P}}=8.4 \mathrm{~Hz}, \mathrm{CH}^{\prime \prime} \mathrm{O}\right), 4.08\left(\mathrm{~s}, 3 \mathrm{H}, \mathrm{NCH}_{3}\right)$, 3.75-3.65 (m, 4H, N( $\left.\left.\mathrm{CH}_{2} \underline{\mathrm{C}}_{2} \mathrm{Cl}\right)_{2}\right), 3.52-3.32\left(\mathrm{~m}, 12 \mathrm{H}, \mathrm{N}\left(\mathrm{C}_{2} \mathrm{CH}_{2} \mathrm{Cl}\right)_{2}, \underline{\mathrm{CH}}_{2} \mathrm{C}_{2} \mathrm{~N}^{+}\left(\mathrm{C}_{2} \mathrm{CH}_{3}\right)_{2}\right), 3.06$ (s, $\left.3 \mathrm{H}, \mathrm{N}^{+} \mathrm{CH}_{3}\right), 1.36\left(\mathrm{t}, 6 \mathrm{H},{ }^{3} \mathrm{~J}_{\mathrm{H}-\mathrm{H}}=7.2 \mathrm{~Hz}, \mathrm{~N}^{+}\left(\mathrm{CH}_{2} \mathrm{C}_{3}\right)_{2}\right) ;{ }^{13} \mathrm{C} \mathrm{NMR}\left(126 \mathrm{MHz}, \mathrm{CD}_{3} \mathrm{OD}\right) \delta 147.73\left(\mathrm{C}_{\mathrm{ArNO}}\right)$, $134.70\left(\mathrm{~d},{ }^{3} \mathrm{~J}_{\mathrm{C}-\mathrm{P}}=6.8 \mathrm{~Hz}, \underline{\mathrm{C}_{\mathrm{ArCH}}} \mathrm{CH}_{2}\right), 129.40\left(\mathrm{CH}_{\mathrm{Ar}}\right), 61.25\left(\underline{\mathrm{CH}}_{2} \mathrm{~N}^{+}\left(\mathrm{CH}_{2} \mathrm{CH}_{3}\right)_{2} \mathrm{CH}_{3}\right), 58.37$ (2C, $\left.\mathrm{N}^{+}\left(\underline{\mathrm{CH}}_{2} \mathrm{CH}_{3}\right)_{2}\right), 58.08\left(\mathrm{~d},{ }^{2} \mathrm{~J}_{\mathrm{C}-\mathrm{P}}=4.5 \mathrm{~Hz}, \mathrm{OCH}_{2}\right), 49.86\left(\mathrm{~d}, 2 \mathrm{C},{ }^{2} J_{\mathrm{C}-\mathrm{P}}=4.5 \mathrm{~Hz}, \mathrm{~N}\left(\underline{\mathrm{CH}}_{2} \mathrm{CH}_{2} \mathrm{Cl}\right)_{2}\right), 48.55$ $\left(\mathrm{N}^{+} \mathrm{CH}_{3}\right), 43.14\left(2 \mathrm{C}, \mathrm{N}\left(\mathrm{CH}_{2} \underline{\mathrm{CH}}_{2} \mathrm{Cl}\right)_{2}\right), 35.40\left(\mathrm{CH}_{2} \mathrm{NHP}\right), 35.25\left(\mathrm{NCH}_{3}\right), 8.15\left(2 \mathrm{C}, \mathrm{N}^{+}\left(\mathrm{CH}_{2} \underline{\mathrm{CH}}_{3}\right)_{2}\right) ;{ }^{31}$ P NMR (202 MHz, CD ${ }_{3} \mathrm{OD}$ ) $\delta$ 17.70; HRMS (ESI) m/z 473.1599 [M] ${ }^{+}$(calculated for $\left[\mathrm{C}_{16} \mathrm{H}_{32} \mathrm{Cl}_{2} \mathrm{~N}_{6} \mathrm{O}_{4} \mathrm{P}\right]^{+}$ 473.1594).

\subsubsection{2.}

5-(\{[bis(2-chloroethyl)amino][(1-methyl-2-nitro-1H-imidazol-5yl)methoxy]phosphoryl\}amino)-N,N,N-triethylpentane-1-aminium iodide (29e)

Alkylation of amine 24a (124 mg, $247 \mu \mathrm{mol}$ ) with ethyl iodide ( 6 eq. initially followed by 6 eq at T $4 \mathrm{~h}$ and 6 eq at T $6 \mathrm{~h}$ ) using the standard procedure (reaction time: $16 \mathrm{~h}$ ) afforded compound 29e analytically pure, as a yellow hygroscopic solid (146 mg, $222 \mu \mathrm{mol})$. Yield 90\%; IR (ATR) v cm1 3416, 3210, 1537, 1488, 1349, 1217, 1189, 1004, 978, 959, 835, 772, 744; ${ }^{1}$ H NMR (500 MHz, $\left.\mathrm{CD}_{3} \mathrm{OD}\right) \delta 7.26\left(\mathrm{~s}, 1 \mathrm{H}, \mathrm{CH}_{\mathrm{Ar}}\right), 5.17\left(\mathrm{dd}, 1 \mathrm{H},{ }^{2} \jmath_{\mathrm{H}-\mathrm{H}}=13.4 \mathrm{~Hz},{ }^{3} J_{\mathrm{H}-\mathrm{P}}=8.3 \mathrm{~Hz}, \mathrm{CH}^{\prime} \mathrm{O}\right), 5.12\left(\mathrm{dd}, 1 \mathrm{H},{ }^{2} J_{\mathrm{H}-\mathrm{H}}\right.$ $\left.=13.4 \mathrm{~Hz},{ }^{3} \mathrm{H}_{\mathrm{H}-\mathrm{P}}=8.6 \mathrm{~Hz}, \mathrm{CH}^{\prime \prime} \mathrm{O}\right), 4.08\left(\mathrm{~s}, 3 \mathrm{H}, \mathrm{NCH}_{3}\right), 3.70-3.62\left(\mathrm{~m}, 4 \mathrm{H}, \mathrm{N}\left(\mathrm{CH}_{2} \mathrm{C}_{2} \mathrm{Cl}_{2}\right), 3.50-3.32(\mathrm{~m}\right.$, $\left.4 \mathrm{H}, \mathrm{N}\left(\mathrm{C}_{2} \mathrm{CH}_{2} \mathrm{Cl}\right)_{2}\right), 3.35\left(\mathrm{q}, 6 \mathrm{H},{ }^{3} \mathrm{H}_{\mathrm{H}-\mathrm{H}}=7.2 \mathrm{~Hz}, \mathrm{~N}^{+}\left(\mathrm{C}_{2} \mathrm{CH}_{3}\right)_{3}\right), 3.24-3.20\left(\mathrm{~m}, 2 \mathrm{H}, \mathrm{CH}_{2} \mathrm{C}_{2} \mathrm{~N}^{+}\right), 2.91$ (td, $\left.2 \mathrm{H},{ }^{3} \mathrm{~J}_{\mathrm{H}-\mathrm{P}}=11.1 \mathrm{~Hz},{ }^{3} \mathrm{~J}_{\mathrm{H}-\mathrm{H}}=6.8 \mathrm{~Hz}, \underline{\mathrm{H}}_{2} \mathrm{NHP}\right), 1.75-1.68\left(\mathrm{~m}, 2 \mathrm{H}, \mathrm{C}_{2} \mathrm{CH}_{2} \mathrm{~N}^{+}\right), 1.60\left(\mathrm{qt}, 2 \mathrm{H},{ }^{3} \mathrm{~J}_{\mathrm{H}-\mathrm{H}}=7.1\right.$ 
$\left.\mathrm{Hz}, \mathrm{C}_{2} \mathrm{CH}_{2} \mathrm{NHP}\right), 1.50-1.38\left(\mathrm{~m}, 2 \mathrm{H}, \mathrm{C}_{2} \mathrm{CH}_{2} \mathrm{CH}_{2} \mathrm{NHP}\right), 1.31\left(\mathrm{~m}, 9 \mathrm{H}, \mathrm{N}^{+}\left(\mathrm{CH}_{2} \mathrm{C}_{3}\right)_{3}\right) ;{ }^{13} \mathrm{C}$ NMR (126 $\left.\mathrm{MHz}, \mathrm{CD}_{3} \mathrm{OD}\right) \delta 147.61\left(\mathrm{C}_{\mathrm{Ar}} \mathrm{NO}_{2}\right), 135.12\left(\mathrm{~d},{ }^{3} \mathrm{~J}_{\mathrm{C}-\mathrm{p}}=7.2 \mathrm{~Hz}, \underline{\mathrm{C}}_{\mathrm{Ar}} \mathrm{CH}_{2}\right), 129.29\left(\mathrm{CH}_{\mathrm{Ar}}\right), 58.15\left(\mathrm{CH}_{2} \underline{\mathrm{CH}}_{2} \mathrm{~N}^{+}\right)$, $57.73\left(\mathrm{~d},{ }^{2} \mathrm{~J}_{\mathrm{C}-\mathrm{P}}=4.6 \mathrm{~Hz}, \mathrm{OCH}_{2}\right), 54.04\left(3 \mathrm{C}, \mathrm{N}^{+}\left(\underline{\mathrm{CH}}_{2} \mathrm{CH}_{3}\right)_{3}\right), 50.31\left(\mathrm{~d}, 2 \mathrm{C},{ }^{2} \mathrm{~J}_{\mathrm{C}-\mathrm{P}}=4.7 \mathrm{~Hz}, \mathrm{~N}\left(\underline{\mathrm{CH}}_{2} \mathrm{CH}_{2} \mathrm{Cl}\right)_{2}\right)$, $43.29\left(2 \mathrm{C}, \mathrm{N}\left(\mathrm{CH}_{2} \underline{\mathrm{CH}}_{2} \mathrm{Cl}\right)_{2}\right), 41.42\left(\mathrm{CH}_{2} \mathrm{NHP}\right), 35.30\left(\mathrm{NCH}_{3}\right), 32.20\left(\mathrm{~d},{ }^{3} \mathrm{~J}_{\mathrm{C}-\mathrm{P}}=5.4 \mathrm{~Hz}, \underline{\mathrm{CH}}_{2} \mathrm{CH}_{2} \mathrm{NHP}\right)$, $24.55\left(\underline{\mathrm{CH}_{2}} \mathrm{CH}_{2} \mathrm{CH}_{2} \mathrm{NHP}\right), 22.43\left(\underline{\mathrm{CH}_{2}} \mathrm{CH}_{2} \mathrm{~N}^{+}\right), 7.89\left(3 \mathrm{C}, \mathrm{N}^{+}\left(\mathrm{CH}_{2} \mathrm{CH}_{3}\right)_{3}\right) ;{ }^{31} \mathrm{P}$ NMR (202 MHz, CD $\left.30 D\right) \delta$ 18.40; HRMS (ESI) m/z 529.2231 [M] ${ }^{+}$(calculated for $\left[\mathrm{C}_{20} \mathrm{H}_{40} \mathrm{Cl}_{2} \mathrm{~N}_{6} \mathrm{O}_{4} \mathrm{P}\right]^{+}$529.2220).

4.1.4.13.

4-(\{[bis(2-chloroethyl)amino][(1-methyl-2-nitro-1H-imidazol-5yl)methoxy]phosphoryl\}amino)- $N, N, N$-triethylbutane-1-aminium iodide (29f)

Alkylation of amine 24b (28 mg, $57.8 \mu \mathrm{mol}$ ) with ethyl iodide (18 eq. initially followed by 18 eq after $15 \mathrm{~h}$ ) using the standard procedure (reaction time: $56 \mathrm{~h}$ ) afforded compound $29 \mathrm{f}$ analytically

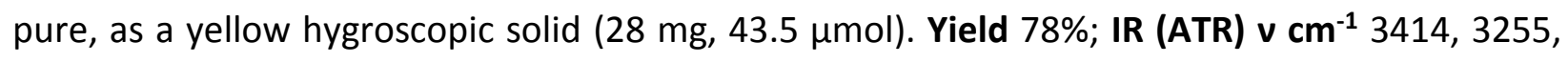
1537, 1488, 1350, 1221, 1190, 1007, 835, 744; ${ }^{1} \mathrm{H}$ NMR (500 MHz, CD ${ }_{3}$ OD) $\delta 7.26$ (s, $1 \mathrm{H}, \mathrm{CH}_{\mathrm{Ar}}$ ), 5.21-5.09 (m, $\left.2 \mathrm{H}, \mathrm{CH}_{2} \mathrm{O}\right), 4.08\left(\mathrm{~s}, 3 \mathrm{H}, \mathrm{NCH}_{3}\right), 3.73-3.61\left(\mathrm{~m}, 4 \mathrm{H}, \mathrm{N}\left(\mathrm{CH}_{2} \mathrm{C}_{2} \mathrm{Cl}\right) 2\right), 3.52-3.32(\mathrm{~m}, 4 \mathrm{H}$, $\left.\mathrm{N}\left(\mathrm{C}_{2} \mathrm{CH}_{2} \mathrm{Cl}\right)_{2}\right), 3.35\left(\mathrm{q}, 6 \mathrm{H},{ }^{3} \mathrm{~J}_{\mathrm{H}-\mathrm{H}}=7.3 \mathrm{~Hz}, \mathrm{~N}^{+}\left(\mathrm{C}_{2} \mathrm{CH}_{3}\right)_{3}\right), 3.24-3.19\left(\mathrm{~m}, 2 \mathrm{H}, \mathrm{CH}_{2} \mathrm{C}_{2} \mathrm{~N}^{+}\right), 2.96(\mathrm{td}, 2 \mathrm{H}$, $\left.{ }^{3} J_{\mathrm{H}-\mathrm{P}}=11.4 \mathrm{~Hz},{ }^{3} \mathrm{~J}_{\mathrm{H}-\mathrm{H}}=6.7 \mathrm{~Hz}, \underline{\mathrm{H}}_{2} \mathrm{NHP}\right), 1.79-1.72\left(\mathrm{~m}, 2 \mathrm{H}, \underline{\mathrm{C}}_{2} \mathrm{CH}_{2} \mathrm{~N}^{+}\right), 1.63-1.53(\mathrm{~m}, 2 \mathrm{H}$, $\mathrm{C}_{2} \mathrm{CH}_{2} \mathrm{NHP}$ ), 1.36-1.28 (m, 9H, N $\left.{ }^{+}\left(\mathrm{CH}_{2} \mathrm{C}_{3}\right)_{3}\right) ;{ }^{13} \mathrm{C}$ NMR (126 MHz, CD 30 D) $\delta 147.65\left(\mathrm{C}_{\mathrm{ArNO}}\right)_{2}$, $135.04\left(d,{ }^{3} J_{C-P}=7.3 \mathrm{~Hz}, \underline{C}_{A r} C_{2}\right), 129.26\left(\mathrm{CH}_{\mathrm{Ar}}\right), 57.92\left(\mathrm{CH}_{2} \underline{\mathrm{CH}}_{2} \mathrm{~N}^{+}\right), 57.76\left(d,{ }^{2} J_{C-P}=4.6 \mathrm{~Hz}, \mathrm{OCH}_{2}\right)$, $54.07\left(3 \mathrm{C}, \mathrm{N}^{+}\left(\underline{\mathrm{C}}_{2} \mathrm{CH}_{3}\right)_{3}\right), 50.24\left(\mathrm{~d}, 2 \mathrm{C},{ }^{2} \mathrm{~J}_{\mathrm{C}-\mathrm{P}}=4.6 \mathrm{~Hz}, \mathrm{~N}\left(\underline{\mathrm{CH}}_{2} \mathrm{CH}_{2} \mathrm{Cl}\right)_{2}\right), 43.25\left(2 \mathrm{C}, \mathrm{N}\left(\mathrm{CH}_{2} \underline{\mathrm{C}} \mathrm{H}_{2} \mathrm{Cl}\right)_{2}\right), 41.19$ $\left(\mathrm{CH}_{2} \mathrm{NHP}\right), 35.27\left(\mathrm{NCH}_{3}\right), 29.56\left(\mathrm{~d},{ }^{3} \mathrm{~J}_{\mathrm{C}-\mathrm{P}}=4.7 \mathrm{~Hz}, \underline{\mathrm{C}} \mathrm{H}_{2} \mathrm{CH}_{2} \mathrm{NHP}\right), 20.29\left(\underline{\mathrm{CH}}_{2} \mathrm{CH}_{2} \mathrm{~N}^{+}\right), 7.85$ (3C, $\left.\mathrm{N}^{+}\left(\mathrm{CH}_{2} \mathrm{CH}_{3}\right)_{3}\right) ;{ }^{31} \mathrm{P}$ NMR (202 MHz, CD 3 OD) $\delta$ 18.34; HRMS (ESI) m/z $515.2049[\mathrm{M}]^{+}$(calculated for $\left[\mathrm{C}_{19} \mathrm{H}_{38} \mathrm{Cl}_{2} \mathrm{~N}_{6} \mathrm{O}_{4} \mathrm{P}\right]^{+}$515.2064).

4.1.4.14. 3-(\{[bis(2-chloroethyl)amino][(1-methyl-2-nitro-1H-imidazol-5yl)methoxy]phosphoryl\}amino)-N,N,N-triethylpropane-1-aminium iodide (29g)

Alkylation of amine $24 \mathrm{c}$ (19 mg, $39.7 \mu \mathrm{mol}$ ) with ethyl iodide (12 eq. initially followed by $12 \mathrm{eq}$ at $\mathrm{T} 24 \mathrm{~h}$ and 12 eq at T $36 \mathrm{~h}$ ) using the standard procedure (reaction time: $72 \mathrm{~h}$ ) and purification by preparative high performance liquid chromatography (gradient ACN in water) afforded compound 29g as a hygroscopic lyophilisate. Yield 23\%; IR (ATR) v cm $\mathbf{~ m}^{-1}$ 3431, 3229 ( $\left.\mathbf{V}_{\mathrm{NH}}\right), 1537$ 
$\left(\delta_{\mathrm{NH}}\right), 1489$ ( $\left.\mathrm{V}_{\text {asNO2 }}\right), 1351\left(\mathrm{~V}_{\mathrm{sNO}}\right), 1215,1190\left(\mathrm{~V}_{\mathrm{P}=\mathrm{O}}, \mathrm{V}_{\mathrm{C}-\mathrm{N}}\right), 1008,982,960\left(\mathrm{~V}_{\mathrm{P}-\mathrm{O}}, \mathrm{V}_{\mathrm{C}-\mathrm{O}}, \mathrm{V}_{\mathrm{P}-\mathrm{N}}\right), 836\left(\delta_{\mathrm{NH}}\right)$, $745\left(\delta_{\mathrm{CH}}\right) ;{ }^{1} \mathrm{H}$ NMR (500 MHz, CD $\left.{ }_{3} \mathrm{OD}\right) \delta 7.26\left(\mathrm{~s}, 1 \mathrm{H}, \mathrm{CH}_{\mathrm{Ar}}\right), 5.18\left(\mathrm{dd}, 1 \mathrm{H},{ }^{2} \mathrm{~J}_{\mathrm{H}-\mathrm{H}}=13.4 \mathrm{~Hz},{ }^{3} \mathrm{~J}_{\mathrm{H}-\mathrm{P}}=8.4\right.$ $\left.\mathrm{Hz}, \mathrm{CH}^{\prime} \mathrm{O}\right), 5.14\left(\mathrm{dd}, 1 \mathrm{H},{ }^{2} \mathrm{~J}_{\mathrm{H}-\mathrm{H}}=13.4 \mathrm{~Hz},{ }^{3} \mathrm{~J}_{\mathrm{H}-\mathrm{P}}=8.5 \mathrm{~Hz}, \mathrm{CH}^{\prime \prime} \mathrm{O}\right), 4.08\left(\mathrm{~s}, 3 \mathrm{H}, \mathrm{NCH}_{3}\right), 3.74-3.64(\mathrm{~m}, 4 \mathrm{H}$, $\left.\mathrm{N}\left(\mathrm{CH}_{2} \mathrm{C}_{2} \mathrm{Cl}\right)_{2}\right), 3.63-3.25\left(\mathrm{~m}, 12 \mathrm{H}, \mathrm{N}\left(\mathrm{C}_{2} \mathrm{CH}_{2} \mathrm{Cl}\right)_{2}, \underline{\mathrm{C}}_{2} \mathrm{~N}^{+}\left(\mathrm{C}_{2} \mathrm{CH}_{3}\right)_{3}\right), 3.00\left(\mathrm{td}, 2 \mathrm{H}, 3^{3} \mathrm{~J}_{-\mathrm{P}}=12.2 \mathrm{~Hz},{ }^{3} \mathrm{~J}_{\mathrm{H}}\right.$ $\left.\mathrm{H}=6.4 \mathrm{~Hz}, \mathrm{CH}_{2} \mathrm{NHP}\right), 1.98-1.80\left(\mathrm{~m}, 2 \mathrm{H}, \underline{\mathrm{C}}_{2} \mathrm{CH}_{2} \mathrm{NHP}\right), 1.31\left(\mathrm{t}, 9 \mathrm{H},{ }^{3} \mathrm{~J}_{\mathrm{H}-\mathrm{H}}=6.2 \mathrm{~Hz}, \mathrm{~N}^{+}\left(\mathrm{CH}_{2} \mathrm{C}_{3}\right)_{3}\right) ;{ }^{13} \mathrm{C}$ NMR (126 MHz, CD $\mathrm{OD}) \delta 147.68\left(\mathrm{C}_{\mathrm{ArNO}} \mathrm{NO}_{2}\right), 134.89$ (d, $\left.{ }^{3} \mathrm{~J}_{\mathrm{C}-\mathrm{P}}=7.3 \mathrm{~Hz}, \underline{\mathrm{C}}_{\mathrm{Ar}} \mathrm{CH}_{2}\right), 129.27\left(\mathrm{CH}_{\mathrm{Ar}}\right), 57.85$ $\left(d,{ }^{2} J_{C-P}=4.6 \mathrm{~Hz}, \mathrm{OCH}_{2}\right), 56.14\left(\mathrm{CH}_{2} \underline{C H}_{2} \mathrm{~N}^{+}\right), 54.16\left(3 \mathrm{C}, \mathrm{N}^{+}\left(\underline{C}_{2} \mathrm{CH}_{3}\right)_{3}\right), 50.07\left(d, 2{ },{ }^{2} J_{C-P}=4.7 \mathrm{~Hz}\right.$, $\left.\mathrm{N}\left(\underline{\mathrm{CH}}_{2} \mathrm{CH}_{2} \mathrm{Cl}\right)_{2}\right), 43.18\left(2 \mathrm{C}, \mathrm{N}\left(\mathrm{CH}_{2} \underline{\mathrm{CH}}_{2} \mathrm{Cl}\right)_{2}\right), 38.81\left(\mathrm{C}_{2} \mathrm{NHP}\right), 35.23\left(\mathrm{NCH}_{3}\right), 25.15\left(\mathrm{~d}, 3^{3} \mathrm{C}_{-\mathrm{P}}=5.5 \mathrm{~Hz}\right.$, $\mathrm{CH}_{2} \mathrm{CH}_{2} \mathrm{NHP}$ ), 7.82 (3C, $\left.\mathrm{N}^{+}\left(\mathrm{CH}_{2} \mathrm{CH}_{3}\right)_{3}\right) ; \mathrm{NMR}{ }^{31} \mathrm{P}$ (202 MHz, CD $\left.{ }_{3} \mathrm{OD}\right) \delta$ 18.03; HRMS (ESI) m/z $501.1895[\mathrm{M}]^{+}$(calculated for $\left[\mathrm{C}_{18} \mathrm{H}_{36} \mathrm{Cl}_{2} \mathrm{~N}_{6} \mathrm{O}_{4} \mathrm{P}\right]^{+}$501.1907).

4.1.4.15.

2-(\{[bis(2-chloroethyl)amino][(1-methyl-2-nitro-1H-imidazol-5yl)methoxy]phosphoryl\}amino)-N,N,N-triethylethane-1-aminium iodide (29h)

Alkylation of amine $\mathbf{2 4 d}$ (70 mg, $153 \mu \mathrm{mol}$ ) with ethyl iodide (12 eq. initially followed by 12 eq after $26 \mathrm{~h}$ ) using the standard procedure (reaction time: $50 \mathrm{~h}$ ) and purification by preparative high performance liquid chromatography (gradient ACN in water) afforded compound $\mathbf{2 9} \mathbf{h}$ as a hygroscopic lyophilisate (57 mg, $92 \mu \mathrm{mol}$ ). Yield 60\%; IR (ATR) v cm $\mathbf{~}^{-1}$ 3438, 3182, 1537, 1489, 1350, 1222, 1190, 1001, 958, 834, 770; ${ }^{1} \mathrm{H}$ NMR (500 MHz, CD ${ }_{3} \mathrm{OD}$ ) $\delta 7.27$ (s, $1 \mathrm{H}, \mathrm{CH}_{\mathrm{Ar}}$ ), 5.20 (dd, $\left.1 \mathrm{H},{ }^{2} J_{\mathrm{H}-\mathrm{H}}=13.4 \mathrm{~Hz},{ }^{3} \mathrm{~J}_{\mathrm{H}-\mathrm{P}}=8.4 \mathrm{~Hz}, \mathrm{CH}^{\prime} \mathrm{O}\right), 5.17\left(\mathrm{dd}, 1 \mathrm{H},{ }^{2} \mathrm{~J}_{\mathrm{H}-\mathrm{H}}=13.4 \mathrm{~Hz},{ }^{3} \mathrm{~J}_{\mathrm{H}-\mathrm{P}}=8.4 \mathrm{~Hz}, \mathrm{CH}^{\prime \prime} \mathrm{O}\right), 4.08(\mathrm{~s}$, $\left.3 \mathrm{H}, \mathrm{NCH}_{3}\right), 3.74-3.65\left(\mathrm{~m}, 4 \mathrm{H}, \mathrm{N}\left(\mathrm{CH}_{2} \mathrm{C}_{2} \mathrm{Cl}\right)_{2}\right), 3.53-3.34\left(\mathrm{~m}, 4 \mathrm{H}, \mathrm{N}\left(\mathrm{CH}_{2} \mathrm{CH}_{2} \mathrm{Cl}\right)_{2}\right), 3.38\left(\mathrm{q},{ }^{3} \mathrm{~J}_{\mathrm{H}-\mathrm{H}}=7.3\right.$ $\left.\mathrm{Hz}, \mathrm{N}^{+}\left(\mathrm{C}_{2} \mathrm{CH}_{3}\right)_{3}\right), 3.33-3.25\left(\mathrm{~m}, 4 \mathrm{H}, \mathrm{CH}_{2} \mathrm{CH}_{2} \mathrm{~N}^{+}\right), 1.33\left(\mathrm{t}, 9 \mathrm{H},{ }^{3} \mathrm{~J}_{\mathrm{H}-\mathrm{H}}=7.2 \mathrm{~Hz}, \mathrm{~N}^{+}\left(\mathrm{CH}_{2} \mathrm{C}_{3}\right)_{3}\right) ;{ }^{13} \mathrm{C} \mathbf{N M R}$ (126 MHz, CD 3 OD) $\delta 147.75\left(\mathrm{C}_{\mathrm{Ar}} \mathrm{NO}_{2}\right), 134.67$ (d, $\left.{ }^{3} \mathrm{~J}_{\mathrm{C}-\mathrm{p}}=7.3 \mathrm{~Hz}, \underline{\mathrm{C}}_{\mathrm{Ar}} \mathrm{CH}_{2}\right), 129.43\left(\mathrm{CH}_{\mathrm{Ar}}\right), 58.11$ (d, $\left.{ }^{2} J_{\mathrm{C}-\mathrm{P}}=4.6 \mathrm{~Hz}, \mathrm{OCH}_{2}\right), 57.79\left(\mathrm{CH}_{2} \underline{\mathrm{CH}}_{2} \mathrm{~N}^{+}\right), 54.58\left(3 \mathrm{C}, \mathrm{N}^{+}\left(\underline{\mathrm{CH}}_{2} \mathrm{CH}_{3}\right)_{3}\right), 49.95\left(\mathrm{~d}, 2 \mathrm{C},{ }^{2} J_{\mathrm{C}-\mathrm{P}}=4.7 \mathrm{~Hz}\right.$, $\left.\mathrm{N}\left(\mathrm{CH}_{2} \mathrm{CH}_{2} \mathrm{Cl}\right)_{2}\right), 43.17\left(\mathrm{~d}, 2 \mathrm{C},{ }^{3} \mathrm{~J}_{\mathrm{C}-\mathrm{P}}=1.6 \mathrm{~Hz}, \mathrm{~N}\left(\mathrm{CH}_{2} \mathrm{CH}_{2} \mathrm{Cl}\right)_{2}\right), 35.02\left(\mathrm{CH}_{2} \mathrm{NHP}\right), 35.21\left(\mathrm{NCH}_{3}\right), 7.82(3 \mathrm{C}$, $\left.\mathrm{N}^{+}\left(\mathrm{CH}_{2} \underline{\mathrm{CH}}_{3}\right)_{3}\right) ; \mathrm{NMR}^{31} \mathrm{P}$ (202 MHz, CD ${ }_{3} \mathrm{OD}$ ) $\delta$ 17.88; HRMS (ESI) m/z $487.1760[\mathrm{M}]^{+}$(calculated for $\left[\mathrm{C}_{17} \mathrm{H}_{34} \mathrm{Cl}_{2} \mathrm{~N}_{6} \mathrm{O}_{4} \mathrm{P}\right]^{+}$487.1751). 
4.1.4.16.

5-(\{[bis(2-chloroethyl)amino][(1-methyl-2-nitro-1H-imidazol-5yl)methoxy]phosphoryl\}amino)-N,N-diisopropyl-N-methyl-pentane-1-aminium iodide (30a) Alkylation of amine 25a (67 mg, $126 \mu \mathrm{mol}$ ) with methyl iodide ( 6 eq. initially followed by 6 eq at T 20h, 6 eq at T 24h and 6 eq at T 28h) using the standard procedure (reaction time: $48 \mathrm{~h}$ ) afforded in quantitative yield, compound 30a analytically pure, as a yellow hygroscopic solid (85 mg, 126 mmol). IR (ATR) v cm ${ }^{-1}$ 3411, 1537, 1489, 1351, 1190, 1014, 961, 835, 743; ${ }^{1}$ H NMR (500 MHz, $\left.\mathrm{CD}_{3} \mathrm{OD}\right) \boldsymbol{\delta} 7.26\left(\mathrm{~s}, 1 \mathrm{H}, \mathrm{CH}_{\mathrm{Ar}}\right), 5.17\left(\mathrm{dd}, 1 \mathrm{H},{ }^{2} \mathrm{~J}_{\mathrm{H}-\mathrm{H}}=13.4 \mathrm{~Hz},{ }^{3} \mathrm{~J}_{\mathrm{H}-\mathrm{P}}=8.2 \mathrm{~Hz}, \mathrm{CH}^{\prime} \mathrm{O}\right), 5.13\left(\mathrm{dd}, 1 \mathrm{H},{ }^{2} J_{\mathrm{H}-\mathrm{H}}=\right.$ $\left.13.4 \mathrm{~Hz},{ }^{3} \mathrm{~J}_{\mathrm{H}-\mathrm{P}}=8.6 \mathrm{~Hz}, \mathrm{CH}^{\prime \prime} \mathrm{O}\right), 4.08\left(\mathrm{~s}, 3 \mathrm{H}, \mathrm{NCH}_{3}\right.$ ), 3.99 (hept, $\left.2 \mathrm{H},{ }^{3} \mathrm{~J}_{\mathrm{H}-\mathrm{H}}=6.6 \mathrm{~Hz}, \mathrm{CH}_{(}\left(\mathrm{CH}_{3}\right)_{2}\right), 3.74-$ $3.62\left(\mathrm{~m}, 4 \mathrm{H}, \mathrm{N}\left(\mathrm{CH}_{2} \mathrm{C}_{2} \mathrm{Cl}\right)_{2}\right)$, 3.51-3.34 (m, 4H, N( $\left.\left.\underline{\mathrm{H}}_{2} \mathrm{CH}_{2} \mathrm{Cl}\right)_{2}\right), 3.33-3.25\left(\mathrm{~m}, 2 \mathrm{H}, \mathrm{CH}_{2} \mathrm{~N}^{+}\right)$, 2.96-2.87 (m, $\left.2 \mathrm{H}, \underline{\mathrm{C}}_{2} \mathrm{NHP}\right), 2.94\left(\mathrm{~s}, 3 \mathrm{H}, \mathrm{N}^{+} \mathrm{CH}_{3}\right), 1.88-1.77\left(\mathrm{~m}, 2 \mathrm{H}, \mathrm{C}_{2} \mathrm{CH}_{2} \mathrm{~N}^{+}\right), 1.60\left(\mathrm{qt}, 2 \mathrm{H},{ }^{3} \mathrm{H}-\mathrm{H}=7.1 \mathrm{~Hz}\right.$, $\left.\mathrm{C}_{2} \mathrm{CH}_{2} \mathrm{NHP}\right), 1.47\left(\mathrm{~d}, 3^{3} \mathrm{H}_{-\mathrm{H}}=6.3 \mathrm{~Hz}, \mathrm{CH}\left(\underline{\mathrm{CH}}_{3}\right)_{2}\right), 1.44-1.38\left(\mathrm{~m}, 2 \mathrm{H}, \underline{\mathrm{C}}_{2} \mathrm{CH}_{2} \mathrm{CH}_{2} \mathrm{NHP}\right) ;{ }^{13} \mathrm{C}$ NMR (126 $\left.\mathrm{MHz}, \mathrm{CD}_{3} \mathrm{OD}\right) \delta 147.60\left(\mathrm{C}_{\mathrm{Ar}} \mathrm{NO}_{2}\right), 135.12\left(\mathrm{~d},{ }^{3} \mathrm{~J}_{\mathrm{C}-\mathrm{P}}=7.1 \mathrm{~Hz}, \underline{\mathrm{C}}_{\mathrm{Ar}} \mathrm{CH}_{2}\right), 129.29\left(\mathrm{CH}_{\mathrm{Ar}}\right), 64.92$ (2C, $\left.\underline{\mathrm{C}}\left(\mathrm{CH}_{3}\right)_{2}\right), 58.34\left(\mathrm{CH}_{2} \mathrm{~N}^{+}\right), 57.74\left(\mathrm{~d},{ }^{2} \mathrm{~J}_{\mathrm{C}-\mathrm{P}}=4.7 \mathrm{~Hz}, \mathrm{OCH}_{2}\right), 50.31\left(\mathrm{~d}, 2 \mathrm{C},{ }^{2} \mathrm{~J}_{\mathrm{C}-\mathrm{P}}=4.7 \mathrm{~Hz}, \mathrm{~N}\left(\mathrm{CH}_{2} \mathrm{CH}_{2} \mathrm{Cl}\right)_{2}\right)$, $44.17\left(\mathrm{~N}^{+} \mathrm{CH}_{3}\right), 43.30\left(2 \mathrm{C}, \mathrm{N}\left(\mathrm{CH}_{2} \underline{\mathrm{CH}}_{2} \mathrm{Cl}\right)_{2}\right), 41.45\left(\mathrm{CH}_{2} \mathrm{NHP}\right), 35.32\left(\mathrm{NCH}_{3}\right), 32.13\left(\mathrm{~d},{ }^{3} \mathrm{~J}_{\mathrm{C}-\mathrm{P}}=5.6 \mathrm{~Hz}\right.$, $\left.\underline{\mathrm{C}_{2}} \mathrm{CH}_{2} \mathrm{NHP}\right), 25.11\left(\underline{\mathrm{C}} \mathrm{H}_{2} \mathrm{CH}_{2} \mathrm{CH}_{2} \mathrm{NHP}\right), 24.79\left(\underline{\mathrm{CH}}_{2} \mathrm{CH}_{2} \mathrm{~N}^{+}\right), 17.96,17.69$ (4C, $\left.\mathrm{CH}\left(\underline{\mathrm{C}} \mathrm{H}_{3}\right)_{2}\right) ;{ }^{31} \mathbf{P}$ NMR (202 MHz, CD ${ }_{3} \mathrm{OD}$ ) $\delta$ 18.39; HRMS (ESI) m/z 543.2384 [M] ${ }^{+}$(calculated for $\left[\mathrm{C}_{21} \mathrm{H}_{42} \mathrm{Cl}_{2} \mathrm{~N}_{6} \mathrm{O}_{4} \mathrm{P}\right]^{+}$ 543.2377).

\subsubsection{7.}

4-(\{[bis(2-chloroethyl)amino][(1-methyl-2-nitro-1H-imidazol-5yl)methoxy]phosphoryl\}amino)- $\mathrm{N}, \mathrm{N}$-diisopropyl-N-methyl-butane-1-aminium iodide (30b) Alkylation of amine 25b (72 mg, $141 \mu \mathrm{mol}$ ) with methyl iodide (12 eq. initially followed by 12 eq after $3 \mathrm{~h}$ ) using the standard procedure (reaction time: $72 \mathrm{~h}$ ) afforded compound $30 \mathrm{~b}$ analytically

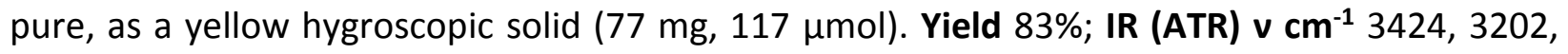
1537, 1489, 1350, 1219, 1190, 1007, 980, 960, 835, 743; ${ }^{1} \mathrm{H}$ NMR (200 MHz, CD OD) $^{\delta}$ (ppm) 7.26 (s, $\left.1 \mathrm{H}, \mathrm{CH}_{\mathrm{Ar}}\right), 5.25-5.04\left(\mathrm{~m}, 2 \mathrm{H}, \mathrm{CH}_{2} \mathrm{O}\right), 4.08\left(\mathrm{~s}, 3 \mathrm{H}, \mathrm{NCH}_{3}\right), 4.02-3.92\left(\mathrm{~m}, 2 \mathrm{H}, \mathrm{C} \underline{\mathrm{H}}\left(\mathrm{CH}_{3}\right)_{2}\right), 3.75-3.60$ $\left(\mathrm{m}, 4 \mathrm{H}, \mathrm{N}\left(\mathrm{CH}_{2} \mathrm{C}_{2} \mathrm{Cl}\right)_{2}\right), 3.55-3.34\left(\mathrm{~m}, 6 \mathrm{H}, \mathrm{N}\left(\mathrm{C}_{2} \mathrm{CH}_{2} \mathrm{Cl}\right)_{2}, \mathrm{CH}_{2} \mathrm{~N}^{+}\right), 3.05-2.86\left(\mathrm{~m}, 2 \mathrm{H}, \mathrm{CH}_{2} \mathrm{NHP}\right), 2.93$ (s, 3H, N $\left.{ }^{+} \underline{\mathrm{H}}_{3}\right), 1.93-1.73\left(\mathrm{~m}, 2 \mathrm{H}, \underline{\mathrm{C}}_{2} \mathrm{CH}_{2} \mathrm{~N}^{+}\right), 1.64-1.40\left(\mathrm{~m}, 2 \mathrm{H}, \underline{\mathrm{C}}_{2} \mathrm{CH}_{2} \mathrm{NHP}\right), 1.47\left(\mathrm{~d}, 12 \mathrm{H}, 3^{3} \mathrm{H}_{-\mathrm{H}}=\right.$ $\left.6.5 \mathrm{~Hz}, \mathrm{CH}\left(\mathrm{C}_{3}\right)_{2}\right) ;{ }^{13} \mathrm{C}$ NMR (126 MHz, CD $\left.3 \mathrm{OD}\right) \delta(\mathrm{ppm}) 147.62\left(\mathrm{C}_{\mathrm{Ar}} \mathrm{NO}_{2}\right), 135.06\left(\mathrm{~d},{ }^{3} \mathrm{C}_{\mathrm{C}-\mathrm{p}}=7.2 \mathrm{~Hz}\right.$, $\left.\underline{\mathrm{C}}_{\mathrm{Ar}} \mathrm{CH}_{2}\right), 129.27\left(\mathrm{CH}_{\mathrm{Ar}}\right), 65.21,64.97\left(\mathrm{C} \underline{\mathrm{H}}\left(\mathrm{CH}_{3}\right)_{2}\right), 58.06\left(\mathrm{CH}_{2} \mathrm{~N}^{+}\right), 57.75\left(\mathrm{~d},{ }^{2} \mathrm{~J}_{\mathrm{C}-\mathrm{p}}=4.7 \mathrm{~Hz}, \mathrm{OCH}_{2}\right), 50.24$ 
(d, $\left.2 \mathrm{C},{ }^{2} \mathrm{C}_{\mathrm{C}-\mathrm{P}}=4.7 \mathrm{~Hz}, \mathrm{~N}\left(\underline{\mathrm{C}} \mathrm{H}_{2} \mathrm{CH}_{2} \mathrm{Cl}\right)_{2}\right), 44.19\left(\mathrm{~N}^{+} \mathrm{CH}_{3}\right), 43.26\left(2 \mathrm{C}, \mathrm{N}\left(\mathrm{CH}_{2} \mathrm{CH}_{2} \mathrm{Cl}\right)_{2}\right), 41.12\left(\mathrm{CH}_{2} \mathrm{NHP}\right)$, $35.30\left(\mathrm{NCH}_{3}\right), 30.06\left(\mathrm{~d},{ }^{3} \mathrm{~J}_{\mathrm{C}-\mathrm{P}}=5.4 \mathrm{~Hz}, \underline{\mathrm{C}} \mathrm{H}_{2} \mathrm{CH}_{2} \mathrm{NHP}\right), 22.59\left(\underline{\mathrm{C}} \mathrm{H}_{2} \mathrm{CH}_{2} \mathrm{~N}^{+}\right), 17.95,17.67\left(4 \mathrm{C}, \mathrm{CH}\left(\underline{\mathrm{C}} \mathrm{H}_{3}\right)_{2}\right)$; 31P NMR (202 MHz, CD ${ }_{3} \mathrm{OD}$ ) $\delta$ (ppm) 18.26; HRMS (ESI) m/z 529.2222 [M] $^{+}$(calculated for $\left.\left[\mathrm{C}_{20} \mathrm{H}_{40} \mathrm{Cl}_{2} \mathrm{~N}_{6} \mathrm{O}_{4} \mathrm{P}\right]^{+} 529.2220\right)$.

4.1.4.18.

3-(\{[bis(2-chloroethyl)amino][(1-methyl-2-nitro-1H-imidazol-5yl)methoxy]phosphoryl\}amino)-N,N-diisopropyl-N-methyl-propane-1-aminium iodide (30c) Alkylation of amine $25 \mathrm{c}(50 \mathrm{mg}, 100 \mu \mathrm{mol}$ ) with methyl iodide (12 eq. initially followed by 12 eq after 72 h) using the standard procedure (reaction time: 96 h) afforded compound 30c analytically pure, as a yellow hygroscopic solid (61 mg, $95.3 \mathrm{mmol}$ ). Yield 96\%; IR (ATR) v cm $\mathbf{~}^{-1}$ 3413, 3209, 1537, 1490, 1350, 1217, 1190, 1007, 980, 960, 835, 743; ${ }^{1} \mathbf{H}$ NMR (500 MHz, CD ${ }_{3}$ OD) $\delta(p p m) 7.27\left(\mathrm{~s}, 1 \mathrm{H}, \mathrm{CH}_{\mathrm{Ar}}\right), 5.20\left(\mathrm{dd}, 1 \mathrm{H},{ }^{2} J_{\mathrm{H}-\mathrm{H}}=13.4 \mathrm{~Hz},{ }^{3} J_{\mathrm{H}-\mathrm{P}}=8.1 \mathrm{~Hz}, \mathrm{CH}^{\prime} \mathrm{O}\right), 5.15\left(\mathrm{dd}, 1 \mathrm{H},{ }^{2} J_{\mathrm{H}-\mathrm{H}}=\right.$ $13.4 \mathrm{~Hz}, 3^{3} \mathrm{~J}_{\mathrm{H}-\mathrm{P}}=8.4 \mathrm{~Hz}, \mathrm{CH}^{\prime \prime} \mathrm{O}$ ), $4.08\left(\mathrm{~s}, 3 \mathrm{H}, \mathrm{NCH}_{3}\right.$ ), 3.98 (hept, $\left.2 \mathrm{H},{ }^{3} \mathrm{~J}_{\mathrm{H}-\mathrm{H}}=6.5 \mathrm{~Hz}, \mathrm{C}^{\mathrm{H}}\left(\mathrm{CH}_{3}\right)_{2}\right), 3.74-$ $3.63\left(\mathrm{~m}, 4 \mathrm{H}, \mathrm{N}\left(\mathrm{CH}_{2} \mathrm{C}_{2} \mathrm{Cl}\right)_{2}\right), 3.54-3.33\left(\mathrm{~m}, 6 \mathrm{H}, \mathrm{N}\left(\mathrm{C}_{2} \mathrm{CH}_{2} \mathrm{Cl}\right)_{2}, \mathrm{CH}_{2} \mathrm{~N}^{+}\right)$, 3.04-2.94 (m, 2H, $\left.\underline{\mathrm{H}}_{2} \mathrm{NHP}\right)$, $2.94\left(\mathrm{~s}, 3 \mathrm{H}, \mathrm{N}^{+} \mathrm{C}_{3}\right), 2.06-1.92\left(\mathrm{~m}, 2 \mathrm{H}, \mathrm{CH}_{2} \mathrm{C}_{2} \mathrm{CH}_{2}\right), 1.47\left(\mathrm{~d}, 12 \mathrm{H}, 3^{3} \mathrm{~J}_{\mathrm{H}-\mathrm{H}}=6.4 \mathrm{~Hz}, \mathrm{CH}\left(\mathrm{C}_{3}\right)_{2}\right) ;{ }^{13} \mathrm{C} \mathrm{NMR}$ (126 MHz, CD 3 OD) $\delta 147.59\left(\mathrm{C}_{\mathrm{ArNO}} \mathrm{NO}_{2}\right), 134.95\left(\mathrm{~d},{ }^{3} \mathrm{~J}_{\mathrm{C}-\mathrm{P}}=7.4 \mathrm{~Hz}, \underline{\mathrm{C}}_{\mathrm{Ar}} \mathrm{CH}_{2}\right), 129.31\left(\mathrm{CH}_{\mathrm{Ar}}\right), 65.17,65.11$ $\left(2 \mathrm{C}, \underline{\mathrm{C}}\left(\mathrm{CH}_{3}\right)_{2}\right), 57.89\left(\mathrm{~d},{ }^{2} \mathrm{~J}_{\mathrm{C}-\mathrm{P}}=4.8 \mathrm{~Hz}, \mathrm{OCH}_{2}\right), 56.32\left(\mathrm{CH}_{2} \mathrm{~N}^{+}\right), 50.07\left(\mathrm{~d}, 2 \mathrm{C},{ }^{2} \mathrm{~J}_{\mathrm{C}-\mathrm{P}}=4.7 \mathrm{~Hz}\right.$, $\left.\mathrm{N}\left(\mathrm{CH}_{2} \mathrm{CH}_{2} \mathrm{Cl}\right)_{2}\right), 44.37\left(\mathrm{~N}^{+} \mathrm{CH}_{3}\right), 43.24\left(2 \mathrm{C}, \mathrm{N}\left(\mathrm{CH}_{2} \underline{\mathrm{CH}}_{2} \mathrm{Cl}\right)_{2}\right), 39.14\left(\mathrm{CH}_{2} \mathrm{NHP}\right), 35.37\left(\mathrm{NCH}_{3}\right), 27.26$ (d,

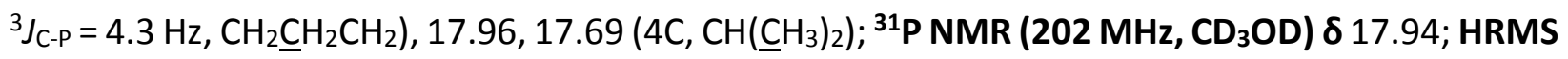
(ESI) $\mathrm{m} / \mathrm{z} 515.2067[\mathrm{M}]^{+}$(calculated for $\left[\mathrm{C}_{19} \mathrm{H}_{38} \mathrm{Cl}_{2} \mathrm{~N}_{6} \mathrm{O}_{4} \mathrm{P}\right]^{+}$515.2064).

\subsubsection{9.}

2-(\{[bis(2-chloroethyl)amino][(1-methyl-2-nitro-1H-imidazol-5yl)methoxy]phosphoryl\}amino)-N,N-diisopropyl-N-methyl-ethane-1-aminium iodide (30d) Alkylation of amine 25d ( $28 \mathrm{mg}, 57.5 \mu \mathrm{mol}$ ) with methyl iodide ( $24 \mathrm{eq}$. initially followed by 24 eq after $15 \mathrm{~h}$ ) using the standard procedure (reaction time: $96 \mathrm{~h}$ ) afforded compound 30d analytically pure, as a yellow hygroscopic solid (30 mg, $47.7 \mathrm{mmol}$ ). Yield 83\%; IR (ATR) v cm ${ }^{-1}$ 3425, 3210, 1537, 1490, 1351, 1220, 1190, 1008, 960, 836, 743; ${ }^{1} \mathbf{H}$ NMR (500 MHz, CD ${ }_{3}$ OD) $\delta$ $7.29\left(\mathrm{~s}, 1 \mathrm{H}, \mathrm{CH}_{\mathrm{Ar}}\right), 5.21\left(\mathrm{dd}, 1 \mathrm{H},{ }^{2} \mathrm{~J}_{\mathrm{H}-\mathrm{H}}=13.4 \mathrm{~Hz},{ }^{3} \mathrm{~J}_{\mathrm{H}-\mathrm{P}}=8.4 \mathrm{~Hz}, \mathrm{CH}^{\prime} \mathrm{O}\right), 5.12\left(\mathrm{dd}, 1 \mathrm{H},{ }^{2} \mathrm{~J}_{\mathrm{H}-\mathrm{H}}=13.4 \mathrm{~Hz}\right.$, $\left.{ }^{3} J_{\mathrm{H}-\mathrm{P}}=8.4 \mathrm{~Hz}, \mathrm{CH}^{\prime \prime} \mathrm{O}\right), 4.08\left(\mathrm{~s}, 3 \mathrm{H}, \mathrm{NCH}_{3}\right), 4.03-3.89\left(\mathrm{~m}, 3 \mathrm{H}, \mathrm{NHP}, \mathrm{C} \underline{\mathrm{H}}\left(\mathrm{CH}_{3}\right)_{2}\right), 3.70\left(\mathrm{td}, 4 \mathrm{H},{ }^{3} \mathrm{~J}_{\mathrm{H}-\mathrm{H}}=6.5\right.$ 
$\left.\mathrm{Hz},{ }^{4} J_{\mathrm{H}-\mathrm{P}}=3.4 \mathrm{~Hz}, \mathrm{~N}\left(\mathrm{CH}_{2} \mathrm{C}_{2} \mathrm{Cl}\right)_{2}\right), 3.52-3.26\left(\mathrm{~m}, 8 \mathrm{H}, \mathrm{N}\left(\mathrm{CH}_{2} \mathrm{CH}_{2} \mathrm{Cl}\right)_{2}, \underline{\mathrm{C}}_{2} \mathrm{C}_{2} \mathrm{NHP}\right), 2.96\left(\mathrm{~s}, 3 \mathrm{H}, \mathrm{N}^{+} \mathrm{CH}_{3}\right)$, 1.43-1.50 (m, 12H, CH( $\left.\left.\left.\underline{C H}_{3}\right)_{2}\right) ;{ }^{13} \mathrm{C} \mathrm{NMR} \mathrm{(126} \mathrm{MHz,} \mathrm{CD}{ }_{3} \mathrm{OD}\right) \delta 147.69\left(\mathrm{C}_{\mathrm{Ar}} \mathrm{NO}_{2}\right), 134.70\left(\mathrm{~d},{ }^{3} J_{\mathrm{C}-\mathrm{p}}=7.2\right.$ $\left.\left.\mathrm{Hz}, \underline{\mathrm{C}}_{\mathrm{Ar}} \mathrm{CH}_{2}\right), 129.45\left(\mathrm{CH}_{\mathrm{Ar}}\right), 65.60,65.54\left(\underline{\mathrm{C}} \mathrm{H}\left(\mathrm{CH}_{3}\right)_{2}\right), 58.16\left(\mathrm{~d},{ }^{2} \mathrm{~J}_{\mathrm{C}-\mathrm{p}}=4.7 \mathrm{~Hz}, \mathrm{OCH}\right)_{2}\right), 57.85\left(\mathrm{~d},{ }^{3} \mathrm{~J}_{\mathrm{C}-\mathrm{p}}=\right.$ $\left.3.1 \mathrm{~Hz}, \mathrm{CH}_{2} \mathrm{~N}^{+}\right), 49.92\left(\mathrm{~d}, 2 \mathrm{C},{ }^{2} \mathrm{~J}_{-\mathrm{p}}=4.7 \mathrm{~Hz}, \mathrm{~N}\left(\mathrm{CH}_{2} \mathrm{CH}_{2} \mathrm{Cl}\right)_{2}\right), 43.75\left(\mathrm{~N}^{+} \mathrm{CH}_{3}\right), 43.22\left(2 \mathrm{C}, \mathrm{N}\left(\mathrm{CH}_{2} \mathrm{CH}_{2} \mathrm{Cl}\right)_{2}\right)$, $36.61\left(\mathrm{CH}_{2} \mathrm{NHP}\right), 35.33\left(\mathrm{NCH}_{3}\right), 17.87,17.50\left(4 \mathrm{C}, \mathrm{CH}\left(\mathrm{CH}_{3}\right)_{2}\right)$; ${ }^{31} \mathrm{P}$ NMR $\left(202 \mathrm{MHz}, \mathrm{CD}_{3} \mathrm{OD}\right) \delta 17.69$; HRMS (ESI) $\mathrm{m} / \mathrm{z} 501.1894[\mathrm{M}]^{+}$(calculated for $\left[\mathrm{C}_{18} \mathrm{H}_{36} \mathrm{Cl}_{2} \mathrm{~N}_{6} \mathrm{O}_{4} \mathrm{P}\right]^{+}$501.1907).

4.1.4.20.

5-(\{[bis(2-chloroethyl)amino][(1-methyl-2-nitro-1H-imidazol-5yl)methoxy]phosphoryl\}amino)-N-benzyl-N,N-dimethylpentane-1-aminium (31a)

Alkylation of amine $26 \mathrm{a}$ (33 mg, $61.3 \mu \mathrm{mol}$ ) with methyl iodide (6 eq.) using the standard procedure (reaction time: $20 \mathrm{~h}$ ) afforded compound 31a analytically pure, as a yellow hygroscopic solid (40 mg, $57.9 \mu \mathrm{mol}$ ). Yield 94\%; IR (ATR) v cm-1 3421, 3220, 1652, 1537, 1488, 1350, 1219,

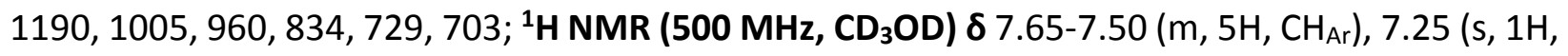
$\left.\mathrm{CH}_{\mathrm{Ar}}\right), 5.16\left(\mathrm{dd}, 1 \mathrm{H},{ }^{2} J_{\mathrm{H}-\mathrm{H}}=13.5 \mathrm{~Hz},{ }^{3} J_{\mathrm{H}-\mathrm{P}}=8.4 \mathrm{~Hz}, \mathrm{CH}^{\prime} \mathrm{O}\right), 5.12\left(\mathrm{dd}, 1 \mathrm{H},{ }^{2} J_{\mathrm{H}-\mathrm{H}}=13.5 \mathrm{~Hz},{ }^{3} J_{\mathrm{H}-\mathrm{P}}=8.9 \mathrm{~Hz}\right.$, $\left.\mathrm{CH}^{\prime \prime} \mathrm{O}\right), 4.57\left(\mathrm{~s}, 2 \mathrm{H}, \mathrm{C}_{2} \mathrm{Ph}\right), 4.07\left(\mathrm{~s}, 3 \mathrm{H}, \mathrm{NCH}_{3}\right), 3.74-3.61\left(\mathrm{~m}, 4 \mathrm{H}, \mathrm{N}\left(\mathrm{CH}_{2} \mathrm{C}_{2} \mathrm{Cl}\right)_{2}\right), 3.51-3.33(\mathrm{~m}, 7 \mathrm{H}$, $\left.\mathrm{N}\left(\mathrm{C}_{2} \mathrm{CH}_{2} \mathrm{Cl}\right)_{2}, \mathrm{CH}_{2} \underline{\mathrm{C}}_{2} \mathrm{~N}^{+}, \mathrm{NHP}\right), 3.05\left(\mathrm{~s}, 6 \mathrm{H}, \mathrm{N}^{+}\left(\underline{\mathrm{C}}_{3}\right)_{2}\right), 2.91$ (tdd, $2 \mathrm{H},{ }^{3} \mathrm{~J}_{\mathrm{H}-\mathrm{P}}=11.1 \mathrm{~Hz},{ }^{3} \mathrm{~J}_{\mathrm{H}-\mathrm{H}}=6.7 \mathrm{~Hz}$, ${ }^{3} J_{\mathrm{H}-\mathrm{H}}=2.0 \mathrm{~Hz}, \underline{\mathrm{C}}_{2} \mathrm{NHP}$ ), $1.94-1.87\left(\mathrm{~m}, 2 \mathrm{H}, \underline{\mathrm{C}}_{2} \mathrm{CH}_{2} \mathrm{~N}^{+}\right), 1.60$ (qt, $2 \mathrm{H}, 3^{3} \mathrm{H}_{-H}=7.1 \mathrm{~Hz}, \mathrm{C}_{2} \mathrm{CH}_{2} \mathrm{NHP}$ ), 1.47-1.37 (m, 2H, $\left.\underline{\mathrm{H}}_{2} \mathrm{CH}_{2} \mathrm{CH}_{2} \mathrm{NHP}\right) ;{ }^{13} \mathrm{C}$ NMR (126 MHz, CD $\left.3 \mathrm{OD}\right) \delta 147.64\left(\mathrm{C}_{\mathrm{Ar} \mathrm{NO}_{2}}\right), 135.10\left(\mathrm{~d},{ }^{3} J_{\mathrm{C}-}\right.$ $\left.\mathrm{p}=6.9 \mathrm{~Hz}, \underline{\mathrm{C}}_{\mathrm{ArCH}_{2}} \mathrm{O}\right), 134.13\left(\underline{\mathrm{C}}_{\mathrm{Ar}} \mathrm{CH}_{2} \mathrm{~N}\right), 131.95,130.38,129.27,128.89\left(6 \mathrm{C}, \mathrm{CH}_{\mathrm{Ar}}\right), 68.98\left(\underline{\mathrm{CH}}_{2} \mathrm{Ph}\right)$, $65.78\left(\mathrm{CH}_{2} \underline{\mathrm{CH}}_{2} \mathrm{~N}^{+}\right), 57.72\left(\mathrm{~d},{ }^{2} \mathrm{~J}_{\mathrm{C}-\mathrm{P}}=4.7 \mathrm{~Hz}, \mathrm{OCH}_{2}\right), 50.50\left(2 \mathrm{C}, \mathrm{N}^{+}\left(\underline{\mathrm{CH}_{3}}\right)_{2}\right), 50.31\left(\mathrm{~d}, 2 \mathrm{C}^{2}{ }^{2} \mathrm{C}-\mathrm{P}=4.7 \mathrm{~Hz}\right.$, $\left.\mathrm{N}\left(\mathrm{CH}_{2} \mathrm{CH}_{2} \mathrm{Cl}\right)_{2}\right), 43.24\left(2 \mathrm{C}, \mathrm{N}\left(\mathrm{CH}_{2} \underline{\mathrm{CH}}_{2} \mathrm{Cl}\right)_{2}\right), 41.40\left(\mathrm{CH}_{2} \mathrm{NHP}\right), 35.22\left(\mathrm{NCH}_{3}\right), 32.21\left(\mathrm{~d},{ }^{3} \mathrm{~J}_{\mathrm{C}-\mathrm{P}}=5.5 \mathrm{~Hz}\right.$, $\left.\underline{\mathrm{CH}}_{2} \mathrm{CH}_{2} \mathrm{NHP}\right), 24.50\left(\mathrm{C}_{2} \mathrm{CH}_{2} \mathrm{CH}_{2} \mathrm{NHP}\right), 23.35\left(\underline{\mathrm{CH}}_{2} \mathrm{CH}_{2} \mathrm{~N}^{+}\right) ;{ }^{31} \mathrm{P}$ NMR (202 MHz, CD 30 ) $\delta$ 18.27; HRMS (ESI) m/z 563.2047 [M] ${ }^{+}$(calculated for $\left[\mathrm{C}_{23} \mathrm{H}_{38} \mathrm{Cl}_{2} \mathrm{~N}_{6} \mathrm{O}_{4} \mathrm{P}\right]^{+}$563.2064).

4.1.4.21.

4-(\{[bis(2-chloroethyl)amino][(1-methyl-2-nitro-1H-imidazol-5yl)methoxy]phosphoryl\}amino)-N-benzyl-N,N-dimethylbutane-1-aminium iodide (31b)

Alkylation of amine $26 \mathrm{~b}(31 \mathrm{mg}, 56.4 \mu \mathrm{mol}$ ) with methyl iodide (6 eq.) using the standard procedure (reaction time: $20 \mathrm{~h}$ ) afforded in quantitative yield, compound 31b analytically pure, as a yellow hygroscopic solid (38 mg, $56.1 \mu \mathrm{mol}$ ). IR (ATR) v cm $\mathbf{~ c m}^{-1}$ 3419, 3231, 1537, 1489, 1350, 
1216, 1190, 1003, 980, 960, 835, 729, 703; ${ }^{1} \mathrm{H}$ NMR (500 MHz, CD 3 OD) $\delta$ 7.61-7.51 (m, 5H, $\mathrm{CH}_{\mathrm{Ar}}$ ), $7.25\left(\mathrm{~s}, 1 \mathrm{H}, \mathrm{CH}_{\mathrm{Ar}}\right), 5.18\left(\mathrm{dd}, 1 \mathrm{H},{ }^{2} \mathrm{~J}_{\mathrm{H}-\mathrm{H}}=13.7 \mathrm{~Hz},{ }^{3} \mathrm{~J}_{\mathrm{H}-\mathrm{P}}=8.5 \mathrm{~Hz}, \mathrm{CH}^{\prime} \mathrm{O}\right), 5.13\left(\mathrm{dd}, 1 \mathrm{H},{ }^{2} \mathrm{~J}_{\mathrm{H}-\mathrm{H}}=13.7 \mathrm{~Hz}\right.$, $\left.{ }^{3} J_{\mathrm{H}-\mathrm{P}}=8.9 \mathrm{~Hz}, \mathrm{CH}^{\prime \prime} \mathrm{O}\right), 4.57\left(\mathrm{~s}, 2 \mathrm{H}, \underline{\mathrm{C}}_{2} \mathrm{Ph}\right), 4.07\left(\mathrm{~s}, 3 \mathrm{H}, \mathrm{NCH}_{3}\right), 3.70-3.66\left(\mathrm{~m}, 4 \mathrm{H}, \mathrm{N}\left(\mathrm{CH}_{2} \mathrm{C}_{2} \mathrm{Cl}\right)_{2}\right), 3.51-$ $3.34\left(\mathrm{~m}, 6 \mathrm{H}, \mathrm{N}\left(\mathrm{C}_{2} \mathrm{CH}_{2} \mathrm{Cl}\right)_{2}, \mathrm{CH}_{2} \mathrm{C}_{2} \mathrm{~N}^{+}\right), 3.06\left(\mathrm{~s}, 6 \mathrm{H}, \mathrm{N}^{+}\left(\mathrm{C}_{3}\right)_{2}\right), 2.97\left(\mathrm{td}, 2 \mathrm{H},{ }^{3} \mathrm{H}_{\mathrm{H}-\mathrm{P}}=11.4 \mathrm{~Hz},{ }^{3} \int_{\mathrm{H}-\mathrm{H}}=\right.$ $6.8 \mathrm{~Hz}, \underline{\mathrm{C}}_{2} \mathrm{NHP}$ ), $1.99-1.91\left(\mathrm{~m}, 2 \mathrm{H}, \mathrm{CH}_{2} \mathrm{CH}_{2} \mathrm{~N}^{+}\right.$), 1.58 (qt, $2 \mathrm{H},{ }^{3} \mathrm{~J} \mathrm{C}-\mathrm{P}=7.0 \mathrm{~Hz}, \mathrm{CH}_{2} \mathrm{CH}_{2} \mathrm{NHP}$ ); ${ }^{13} \mathrm{C}$ NMR (126 MHz, CD 30 D) $\delta 147.66\left(\mathrm{C}_{\mathrm{Ar}} \mathrm{NO}_{2}\right), 135.02\left(\mathrm{~d},{ }^{3} \mathrm{~J}-\mathrm{P}=7.3 \mathrm{~Hz}, \underline{\mathrm{C}}_{\mathrm{Ar}} \mathrm{CH}_{2} \mathrm{O}\right), 134.13\left(\underline{\mathrm{C}}_{\mathrm{Ar}} \mathrm{CH}_{2} \mathrm{~N}\right), 131.97$, $130.39,129.26,128.86\left(6 \mathrm{C}, \mathrm{CH}_{\mathrm{Ar}}\right), 68.98\left(\underline{\mathrm{CH}_{2}} \mathrm{Ph}\right), 65.45\left(\mathrm{CH}_{2} \underline{\mathrm{CH}}_{2} \mathrm{~N}^{+}\right), 57.79\left(\mathrm{~d},{ }^{2} \mathrm{~J}_{\mathrm{C}-\mathrm{p}}=4.7 \mathrm{~Hz}, \mathrm{OCH}_{2}\right)$, $50.53\left(2 \mathrm{C}, \mathrm{N}^{+}\left(\mathrm{CH}_{3}\right)_{2}\right), 50.26\left(\mathrm{~d}, 2 \mathrm{C},{ }^{2} \mathrm{~J}_{\mathrm{C}-\mathrm{P}}=4.7 \mathrm{~Hz}, \mathrm{~N}\left(\mathrm{CH}_{2} \mathrm{CH}_{2} \mathrm{Cl}\right)_{2}\right), 43.24\left(2 \mathrm{C}, \mathrm{N}\left(\mathrm{CH}_{2} \mathrm{CH}_{2} \mathrm{Cl}\right)_{2}\right), 41.08$ $\left(\mathrm{CH}_{2} \mathrm{NHP}\right), 35.25\left(\mathrm{NCH}_{3}\right), 29.52\left(\mathrm{~d},{ }^{3} \mathrm{~J}_{\mathrm{C}-\mathrm{P}}=5.5 \mathrm{~Hz}, \mathrm{CH}_{2} \mathrm{CH}_{2} \mathrm{NHP}\right), 21.18\left(\underline{\mathrm{CH}}_{2} \mathrm{CH}_{2} \mathrm{~N}^{+}\right)$; ${ }^{31} \mathrm{P}$ NMR (202 $\mathrm{MHz}, \mathrm{CD}_{3} \mathrm{OD}$ ) $\delta$ 18.26; HRMS (ESI) m/z 549.1895 [M] ${ }^{+}$(calculated for $\left[\mathrm{C}_{22} \mathrm{H}_{36} \mathrm{Cl}_{2} \mathrm{~N}_{6} \mathrm{O}_{4} \mathrm{P}\right]^{+}$549.1907).

4.1.4.22.

3-(\{[bis(2-chloroethyl)amino][(1-methyl-2-nitro-1H-imidazol-5yl)methoxy]phosphoryl\}amino)-N-benzyl-N,N-dimethylpropane-1-aminium iodide (31c)

Method A: Alkylation of amine 26c (28 mg, $53.7 \mu \mathrm{mol})$ with methyl iodide (6 eq) using the standard procedure (reaction time: $20 \mathrm{~h}$ ) afforded compound 31c analytically pure, as a yellow hygroscopic solid (33 mg, $49.7 \mu \mathrm{mol}$ ). Yield 93\%.

Method B: Alkylation of amine 23c (52 mg, $117 \mu \mathrm{mol})$ was carried out with 24 equivalents of benzyl iodide ${ }^{44}(351 \mu \mathrm{L}, 2.82 \mathrm{mmol})$ in the presence of potassium carbonate $(97 \mathrm{mg}, 702 \mu \mathrm{mol})$. The work up of the reaction mixture according to the general procedure allowed to obtain a crude product that was dissolved in a minimum amount of water and washed with $\mathrm{DCM}(10 \mathrm{~mL})$. The aqueous layer was decanted and then lyophilised, to afford compound 31c, analytically pure, as a yellow hygroscopic solid (23 mg, $34.7 \mathrm{mmol}$ ). Yield 30\%. IR (ATR) v cm $\mathbf{c m}^{-1}$ 3427, $3214\left(\mathrm{v}_{\mathrm{NH}}\right), 1645$, $1537\left(\delta_{N H}\right), 1489$ ( $\left.v_{a s N O 2}\right), 1350$ ( $\left.v_{s N O 2}\right), 1217,1190$ ( $\left.v_{P=O}, v_{C-N}\right), 1005,977,960$ (VP-O, vC-O, $\left.v_{P-N}\right), 835$ $\left(\delta_{\mathrm{NH}}\right), 729,702\left(\delta_{\mathrm{CH}}\right) ;{ }^{1} \mathrm{H}$ NMR (500 MHz, CD $\left.{ }_{3} \mathrm{OD}\right) \delta$ 7.61-7.51 (m, 5H, $\left.\mathrm{CH}_{\mathrm{Ar}}\right), 7.25\left(\mathrm{~s}, 1 \mathrm{H}, \mathrm{CH}_{\mathrm{Ar}}\right), 5.17$ $\left(\mathrm{dd}, 1 \mathrm{H},{ }^{2} J_{\mathrm{H}-\mathrm{H}}=13.4 \mathrm{~Hz},{ }^{3} J_{\mathrm{H}-\mathrm{P}}=8.3 \mathrm{~Hz}, \mathrm{CH}^{\prime} \mathrm{O}\right), 5.13\left(\mathrm{dd}, 1 \mathrm{H},{ }^{2} J_{\mathrm{H}-\mathrm{H}}=13.4 \mathrm{~Hz},{ }^{3} J_{\mathrm{H}-\mathrm{P}}=8.4 \mathrm{~Hz}, \mathrm{CH}^{\prime \prime O}\right)$, $4.58\left(\mathrm{~s}, 2 \mathrm{H}, \underline{\mathrm{C}}_{2} \mathrm{Ph}\right), 4.07\left(\mathrm{~s}, 3 \mathrm{H}, \mathrm{NCH}_{3}\right), 3.73-3.63\left(\mathrm{~m}, 4 \mathrm{H}, \mathrm{N}\left(\mathrm{CH}_{2} \mathrm{C}_{2}{ }_{2} \mathrm{Cl}\right) 2\right), 3.52-3.35(\mathrm{~m}, 6 \mathrm{H}$, $\left.\mathrm{N}\left(\mathrm{C}_{2} \mathrm{CH}_{2} \mathrm{Cl}\right)_{2}, \mathrm{CH}_{2} \mathrm{C}_{2} \mathrm{~N}^{+}\right), 3.07\left(\mathrm{~s}, 6 \mathrm{H}, \mathrm{N}^{+}\left(\mathrm{C}_{3}\right)_{2}\right), 3.03\left(\mathrm{td}, 2 \mathrm{H},{ }^{3} \mathrm{~J}_{\mathrm{H}-\mathrm{P}}=12.5 \mathrm{~Hz},{ }^{3} \mathrm{~J}_{\mathrm{H}-\mathrm{H}}=6.5 \mathrm{~Hz}\right.$, $\mathrm{C}_{2} \mathrm{NHP}$ ), 2.13-2.05 (m, 2H, $\left.\mathrm{CH}_{2} \mathrm{C}_{2} \mathrm{CH}_{2}\right) ;{ }^{13} \mathrm{C} \mathrm{NMR}$ (126 MHz, CD $\mathrm{CD}_{3} \mathrm{O} 147.68\left(\mathrm{C}_{\mathrm{ArNO}_{2}}\right), 134.89$ $\left(d,{ }^{3} J_{C-P}=7.3 \mathrm{~Hz}, \underline{C}_{A r C H} \mathrm{O}\right), 134.23\left(\underline{C}_{A r} C H_{2} N\right), 131.99,130.40,129.33,128.78\left(6 C, \mathrm{CH}_{A r}\right), 69.31$ 
$\left(\underline{\mathrm{C}} \mathrm{H}_{2} \mathrm{Ph}\right), 63.67\left(\mathrm{CH}_{2} \underline{\mathrm{CH}}_{2} \mathrm{~N}^{+}\right), 57.92\left(\mathrm{~d},{ }^{2} \mathrm{~J}_{\mathrm{C}-\mathrm{P}}=4.8 \mathrm{~Hz}, \mathrm{OCH}_{2}\right), 50.67,50.65\left(\mathrm{~N}^{+}\left(\underline{\mathrm{CH}}_{3}\right)_{2}\right), 50.09(\mathrm{~d}, 2 \mathrm{C}$, $\left.{ }^{2} J_{\mathrm{C}-\mathrm{P}}=4.7 \mathrm{~Hz}, \mathrm{~N}\left(\underline{\mathrm{C}} \mathrm{H}_{2} \mathrm{CH}_{2} \mathrm{Cl}\right)_{2}\right), 43.21\left(2 \mathrm{C}, \mathrm{N}\left(\mathrm{CH}_{2} \mathrm{CH}_{2} \mathrm{Cl}\right)_{2}\right), 38.89\left(\mathrm{CH}_{2} \mathrm{NHP}\right), 35.31\left(\mathrm{NCH}_{3}\right), 26.03$ $\left(\mathrm{CH}_{2} \mathrm{CH}_{2} \mathrm{CH}_{2}\right) ;{ }^{31} \mathrm{P}$ NMR (202 MHz, CD $\left.3 \mathrm{OD}\right) \delta$ 18.01; HRMS (ESI) m/z 535.1750 [M] ${ }^{+}$(calculated for $\left[\mathrm{C}_{21} \mathrm{H}_{34} \mathrm{Cl}_{2} \mathrm{~N}_{6} \mathrm{O}_{4} \mathrm{P}\right]^{+}$535.1751).

4.1.4.23.

2-(\{[bis(2-chloroethyl)amino][(1-methyl-2-nitro-1H-imidazol-5yl)methoxy]phosphoryl\}amino)-N-benzyl-N,N-dimethylethane-1-aminium iodide (31d)

Alkylation of amine $\mathbf{2 6 d}$ ( $24 \mathrm{mg}, 47.3 \mathrm{\mu mol}$ ) with methyl iodide (12 eq.) using the standard procedure (reaction time: $12 \mathrm{~h}$ ) afforded in quantitative yield, compound 31d analytically pure, as a yellow hygroscopic solid (30 mg, $47.3 \mu \mathrm{mol}$ ). IR (ATR) v cm $\mathbf{~ c m}^{-1}$ 3421, 3203, 1537, 1489, 1350, 1217, 1191, 1000, 980, 959, 835, 765, 744, 703; ${ }^{1} \mathrm{H}$ NMR (500 MHz, CD $\left.30 D\right)$ ס 7.63-7.51 (m, 5H, $\left.\mathrm{CH}_{\mathrm{Ar}}\right), 7.25\left(\mathrm{~s}, 1 \mathrm{H}, \mathrm{CH}_{\mathrm{Ar}}\right), 5.19\left(\mathrm{~m}, 2 \mathrm{H}, \mathrm{OCH}_{2}\right), 4.60\left(\mathrm{~s}, 2 \mathrm{H}, \mathrm{CH}_{2} \mathrm{Ph}\right), 4.06\left(\mathrm{~s}, 3 \mathrm{H}, \mathrm{NCH}_{3}\right), 3.69(\mathrm{td}, 4 \mathrm{H}$, $\left.{ }^{3} J_{\mathrm{H}-\mathrm{H}}=6.6 \mathrm{~Hz},{ }^{3} \mathrm{~J}_{\mathrm{H}-\mathrm{P}}=3.1 \mathrm{~Hz}, \mathrm{~N}\left(\mathrm{CH}_{2} \mathrm{C}_{2} \mathrm{Cl}\right)_{2}\right), 3.52-3.34\left(\mathrm{~m}, 8 \mathrm{H}, \mathrm{N}\left(\mathrm{C}_{2} \mathrm{CH}_{2} \mathrm{Cl}\right)_{2}, \underline{\mathrm{C}}_{2} \mathrm{C}_{2} \mathrm{NHP}\right), 3.11(\mathrm{~s}$, $\left.6 \mathrm{H}, \mathrm{N}^{+}\left(\mathrm{CH}_{3}\right)_{2}\right) ;{ }^{13} \mathrm{C}$ NMR (126 MHz, CD 30 D) $\delta 147.70\left(\mathrm{C}_{\mathrm{ArNO}} \mathrm{NO}_{2}\right), 134.65$ (d, $\left.{ }^{3} \mathrm{~J}_{\mathrm{C}-\mathrm{P}}=7.1 \mathrm{~Hz}, \underline{\mathrm{C}}_{\mathrm{Ar}} \mathrm{CH}_{2} \mathrm{O}\right)$,

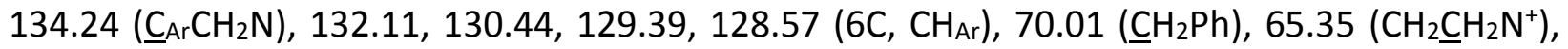
$58.08\left(\mathrm{~d},{ }^{2} \mathrm{~J}_{\mathrm{C}-\mathrm{P}}=4.9 \mathrm{~Hz}, \mathrm{OCH}_{2}\right), 50.96,50.94\left(\mathrm{~N}^{+}\left(\underline{\mathrm{CH}}_{3}\right)_{2}\right), 49.85\left(\mathrm{~d}, 2 \mathrm{C},{ }^{2} \mathrm{~J}_{\mathrm{C}-\mathrm{P}}=4.7 \mathrm{~Hz}, \mathrm{~N}\left(\underline{\mathrm{CH}}_{2} \mathrm{CH}_{2} \mathrm{Cl}\right)_{2}\right)$, $43.12\left(2 \mathrm{C}, \mathrm{N}\left(\mathrm{CH}_{2} \mathrm{CH}_{2} \mathrm{Cl}\right)_{2}\right), 35.91\left(\mathrm{CH}_{2} \mathrm{NHP}\right), 35.24\left(\mathrm{NCH}_{3}\right)$; ${ }^{31} \mathrm{P}$ NMR (202 MHz, CD $\left.3 \mathrm{OD}\right) \delta$ 17.80; HRMS (ESI) m/z $521.1595[\mathrm{M}]^{+}$(calculated for $\left[\mathrm{C}_{20} \mathrm{H}_{32} \mathrm{Cl}_{2} \mathrm{~N}_{6} \mathrm{O}_{4} \mathrm{P}\right]^{+}$521.1594).

\subsubsection{4.}

5-(\{[bis(2-chloroethyl)amino][(1-methyl-2-nitro-1H-imidazol-5yl)methoxy]phosphoryl\}amino)-N-benzyl-N-ethyl-N-methylpentane-1-aminium iodide (31e) Alkylation of amine $26 \mathrm{a}$ (32 $\mathrm{mg}, 58.2 \mathrm{mmol}$ ) with ethyl iodide (18 eq. initially followed by 18 eq at $\mathrm{T} 16 \mathrm{~h}$ and $18 \mathrm{eq}$ at $\mathrm{T} 24 \mathrm{~h}$ ) using the standard procedure (reaction time: $72 \mathrm{~h}$ ) afforded in quantitative yield, compound 31e analytically pure, as a yellow hygroscopic solid (40 mg, 56.7

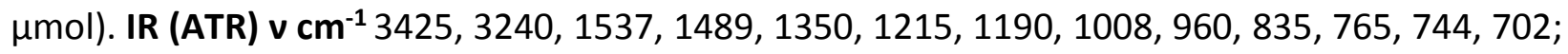
${ }^{1} \mathrm{H}$ NMR (500 MHz, CD 30 D) $\delta$ 7.64-7.50 (m, 5H, $\left.\mathrm{CH}_{\mathrm{Ar}}\right), 7.24\left(\mathrm{~s}, 1 \mathrm{H}, \mathrm{CH}_{\mathrm{Ar}}\right), 5.15\left(\mathrm{dd}, 1 \mathrm{H},{ }^{2} \mathrm{~J}_{\mathrm{H}-\mathrm{H}}=13.3\right.$ $\left.\mathrm{Hz},{ }^{3} J_{\mathrm{H}-\mathrm{P}}=8.3 \mathrm{~Hz}, \mathrm{CH}^{\prime} \mathrm{O}\right), 5.11\left(\mathrm{dd}, 1 \mathrm{H},{ }^{2} \mathrm{~J}_{\mathrm{H}-\mathrm{H}}=13.1 \mathrm{~Hz},{ }^{3} \mathrm{~J}_{\mathrm{H}-\mathrm{P}}=8.1 \mathrm{~Hz}, \mathrm{CH}\right.$ 'O), $4.54\left(\mathrm{~s}, 2 \mathrm{H}, \underline{\mathrm{C}}_{2} \mathrm{Ph}\right)$, $4.07\left(\mathrm{~s}, 3 \mathrm{H}, \mathrm{NCH}_{3}\right), 3.74-3.61\left(\mathrm{~m}, 4 \mathrm{H}, \mathrm{N}\left(\mathrm{CH}_{2} \underline{\mathrm{C}}_{2} \mathrm{Cl}\right)_{2}\right), 3.50-3.33\left(\mathrm{~m}, 6 \mathrm{H}, \mathrm{N}\left(\mathrm{C}_{2} \mathrm{CH}_{2} \mathrm{Cl}\right)_{2}, \mathrm{~N}^{+} \underline{\mathrm{C}}_{2} \mathrm{CH}_{3}\right)$, 3.29-3.18 (m, $\left.2 \mathrm{H}, \mathrm{CH}_{2} \underline{\mathrm{C}}_{2} \mathrm{~N}^{+}\right), 2.96\left(\mathrm{~s}, 3 \mathrm{H}, \mathrm{N}^{+} \mathrm{CH}_{3}\right), 2.94-2.87\left(\mathrm{~m}, 2 \mathrm{H}, \mathrm{C}_{2} \mathrm{NHP}\right), 1.85-1.77(\mathrm{~m}, 2 \mathrm{H}$, 
$\mathrm{C}_{2} \mathrm{CH}_{2} \mathrm{~N}^{+}$), 1.60 (qt, $\left.2 \mathrm{H},{ }^{3} \mathrm{~J}_{\mathrm{H}-\mathrm{H}}=6.9 \mathrm{~Hz}, \mathrm{C}_{2} \mathrm{CH}_{2} \mathrm{NHP}\right), 1.48-1.30\left(\mathrm{~m}, 5 \mathrm{H}, \underline{\mathrm{C}}_{2} \mathrm{CH}_{2} \mathrm{CH}_{2} \mathrm{NHP}, \mathrm{N}^{+} \mathrm{CH}_{2} \mathrm{C}_{3}\right)$; ${ }^{13} \mathrm{C}$ NMR (126 MHz, CD $\left.{ }_{3} \mathrm{OD}\right) \delta 147.65\left(\mathrm{C}_{\mathrm{ArNO}}\right), 135.09$ (d, $\left.{ }^{3} \mathrm{~J}_{\mathrm{C}-\mathrm{P}}=7.0 \mathrm{~Hz}, \underline{\mathrm{C}}_{\mathrm{Ar}} \mathrm{CH}_{2} \mathrm{O}\right), 134.09$ $\left(\underline{\mathrm{C}_{A r}} \mathrm{CH}_{2} \mathrm{~N}\right), 131.88,130.40,129.26,128.78\left(6 \mathrm{C}, \mathrm{CH}_{\mathrm{Ar}}\right), 66.42\left(\underline{\mathrm{C}_{2}} \mathrm{Ph}\right), 61.75\left(\mathrm{CH}_{2} \underline{\mathrm{CH}}_{2} \mathrm{~N}^{+}\right), 57.71$ (d, $\left.{ }^{2} J_{\mathrm{C}-\mathrm{P}}=4.3 \mathrm{~Hz}, \mathrm{OCH}_{2}\right), 57.70\left(\mathrm{~N}^{+} \mathrm{CH}_{2} \mathrm{CH}_{3}\right), 50.30\left(\mathrm{~d}, 2 \mathrm{C},{ }^{2} \mathrm{~J}_{\mathrm{C}-\mathrm{P}}=4.7 \mathrm{~Hz}, \mathrm{~N}\left(\underline{\mathrm{CH}}_{2} \mathrm{CH}_{2} \mathrm{Cl}\right)_{2}\right), 47.86\left(\mathrm{~N}^{+} \mathrm{CH}_{3}\right)$, $43.24\left(2 \mathrm{C}, \mathrm{N}\left(\mathrm{CH}_{2} \underline{\mathrm{CH}}_{2} \mathrm{Cl}\right)_{2}\right), 41.43\left(\mathrm{CH}_{2} \mathrm{NHP}\right), 35.20\left(\mathrm{NCH}_{3}\right), 32.23\left(\mathrm{~d},{ }^{3} \mathrm{~J}_{\mathrm{C}-\mathrm{P}}=5.5 \mathrm{~Hz}, \underline{\mathrm{CH}}_{2} \mathrm{CH}_{2} \mathrm{NHP}\right)$,

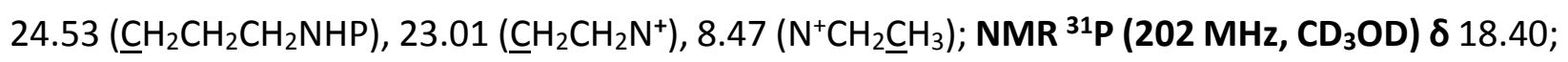
HRMS (ESI) m/z 577.2204 [M] $]^{+}$(calculated for $\left[\mathrm{C}_{24} \mathrm{H}_{40} \mathrm{Cl}_{2} \mathrm{~N}_{6} \mathrm{O}_{4} \mathrm{P}\right]^{+}$577.2220).

4.1.4.25.

4-(\{[bis(2-chloroethyl)amino][(1-methyl-2-nitro-1H-imidazol-5yl)methoxy]phosphoryl\}amino)-N-benzyl- $\mathbf{N}$-ethyl-N-methylbutane-1-aminium iodide (31f)

Alkylation of amine $\mathbf{2 6 b}$ (49 mg, $90.8 \mu \mathrm{mol}$ ) with ethyl iodide (25 eq.) using the standard procedure (reaction time: $48 \mathrm{~h}$ ) and purification by preparative high performance liquid chromatography (gradient ACN in water) afforded compound $\mathbf{3 1 f}$ as a hygroscopic lyophilisate

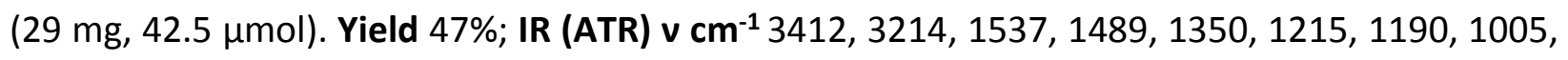
979, 959, 834, 767, 744, 702; ${ }^{1} \mathrm{H}$ NMR (500 MHz, CD $\left.{ }_{3} \mathrm{OD}\right) \boldsymbol{\delta} 7.60-7.50\left(\mathrm{~m}, 5 \mathrm{H}, \mathrm{CH}_{\mathrm{Ar}}\right), 7.25(\mathrm{~s}, 1 \mathrm{H}$, $\left.\mathrm{CH}_{\mathrm{Ar}}\right), 5.17\left(\mathrm{dd}, 2 \mathrm{H},{ }^{2} \mathrm{~J}_{\mathrm{H}-\mathrm{H}}=13.4 \mathrm{~Hz},{ }^{3} \mathrm{~J}_{\mathrm{H}-\mathrm{P}}=8.5 \mathrm{~Hz}, \mathrm{CH}^{\prime} \mathrm{O}\right), 5.13\left(\mathrm{dd}, 2 \mathrm{H},{ }^{2} \mathrm{~J}_{\mathrm{H}-\mathrm{H}}=13.4 \mathrm{~Hz},{ }^{3} J_{\mathrm{H}-\mathrm{P}}=8.5 \mathrm{~Hz}\right.$, $\left.\mathrm{CH}^{\prime \prime} \mathrm{O}\right), 4.55\left(\mathrm{~s}, 2 \mathrm{H}, \mathrm{C}_{2} \mathrm{Ph}\right), 4.07\left(\mathrm{~s}, 3 \mathrm{H}, \mathrm{NCH}_{3}\right), 3.72-3.64\left(\mathrm{~m}, 4 \mathrm{H}, \mathrm{N}\left(\mathrm{CH}_{2} \underline{\mathrm{C}}_{2} \mathrm{Cl}\right)_{2}\right), 3.52-3.19(\mathrm{~m}, 8 \mathrm{H}$, $\left.\mathrm{N}\left(\mathrm{C}_{2} \mathrm{CH}_{2} \mathrm{Cl}\right)_{2}, \underline{\mathrm{C}}_{2} \mathrm{~N}^{+} \underline{\mathrm{H}}_{2} \mathrm{CH}_{3}\right), 3.01-2.93\left(\mathrm{~m}, 2 \mathrm{H}, \underline{\mathrm{C}}_{2} \mathrm{NHP}\right), 2.97\left(\mathrm{~s}, 3 \mathrm{H}, \mathrm{N}^{+} \mathrm{CH}_{3}\right), 2.00-1.82(\mathrm{~m}, 2 \mathrm{H}$, $\mathrm{C}_{2}{ }_{2} \mathrm{CH}_{2} \mathrm{~N}^{+}$), 1.57 (qt, $\left.2 \mathrm{H},{ }^{3} \mathrm{~J}_{\mathrm{H}-\mathrm{H}}=7.2 \mathrm{~Hz}, \mathrm{CH}_{2} \mathrm{CH}_{2} \mathrm{NHP}\right), 1.44\left(\mathrm{t}, 3 \mathrm{H},{ }^{3} \mathrm{~J}_{\mathrm{H}-\mathrm{H}}=7.3 \mathrm{~Hz}, \mathrm{~N}^{+} \mathrm{CH}_{2} \mathrm{C}_{3}\right.$ ); ${ }^{13} \mathrm{C}$ NMR (126 MHz, CD $\left.{ }_{3} \mathrm{OD}\right) \delta 147.62\left(\mathrm{C}_{\mathrm{ArNO}} \mathrm{NO}_{2}\right), 135.05\left(\mathrm{~d},{ }^{3} \mathrm{~J} \mathrm{C}-\mathrm{P}=7.3 \mathrm{~Hz}, \underline{\mathrm{C}}_{A r} \mathrm{CH}_{2} \mathrm{O}\right), 134.12\left(\underline{\mathrm{C}}_{\mathrm{Ar}} \mathrm{CH}_{2} \mathrm{~N}\right), 131.83$, 130.37, 129.29, $128.76\left(6 \mathrm{C}, \mathrm{CH}_{\mathrm{Ar}}\right), 66.36\left(\underline{\mathrm{C}} \mathrm{H}_{2} \mathrm{Ph}\right), 61.48\left(\mathrm{CH}_{2} \underline{\mathrm{CH}}_{2} \mathrm{~N}^{+}\right), 57.81\left(\mathrm{~d},{ }^{2} \mathrm{~J}_{\mathrm{C}-\mathrm{P}}=4.6 \mathrm{~Hz}, \mathrm{OCH}_{2}\right)$, $57.79\left(\mathrm{~N}^{+} \underline{\mathrm{CH}}_{2} \mathrm{CH}_{3}\right), 50.27\left(\mathrm{~d}, 2 \mathrm{C},{ }^{2} \mathrm{~J}_{\mathrm{C}-\mathrm{P}}=4.7 \mathrm{~Hz}, \mathrm{~N}\left(\mathrm{CH}_{2} \mathrm{CH}_{2} \mathrm{Cl}\right)_{2}\right), 47.94\left(\mathrm{~N}^{+} \mathrm{CH}_{3}\right), 43.30$ (2C, $\left.\mathrm{N}\left(\mathrm{CH}_{2} \underline{\mathrm{CH}}_{2} \mathrm{Cl}\right)_{2}\right), 41.11\left(\mathrm{CH}_{2} \mathrm{NHP}\right), 35.36\left(\mathrm{NCH}_{3}\right), 29.50\left(\mathrm{~d},{ }^{3} \mathrm{~J}_{\mathrm{C}-\mathrm{P}}=5.2 \mathrm{~Hz}, \mathrm{CH}_{2} \mathrm{CH}_{2} \mathrm{NHP}\right), 20.97$ $\left(\underline{C}_{2} \mathrm{CH}_{2} \mathrm{~N}^{+}\right), 8.57\left(\mathrm{~N}^{+} \mathrm{CH}_{2} \underline{C H}_{3}\right) ;{ }^{31} \mathrm{P}$ NMR (202 MHz, CD $\left.3 \mathrm{OD}\right) \delta$ 18.29; HRMS (ESI) m/z 563.2048 [M] ${ }^{+}$ (calculated for $\left[\mathrm{C}_{23} \mathrm{H}_{38} \mathrm{Cl}_{2} \mathrm{~N}_{6} \mathrm{O}_{4} \mathrm{P}\right]^{+}$563.2064).

4.1.4.26.

3-(\{[bis(2-chloroethyl)amino][(1-methyl-2-nitro-1H-imidazol-5yl)methoxy]phosphoryl\}amino)-N-benzyl-N-ethyl-N-methylpropane-1-aminium iodide (31g) 
Alkylation of amine $26 \mathrm{c}(32 \mathrm{mg}, 60.7 \mu \mathrm{mol})$ ) with ethyl iodide ( $24 \mathrm{eq}$. initially followed by 24 eq at T $24 \mathrm{~h}$ and 24 eq at T $48 \mathrm{~h}$ ) using the standard procedure (reaction time: $72 \mathrm{~h}$ ) and purification by preparative high performance liquid chromatography (gradient ACN in water) afforded compound 31g as a hygroscopic lyophilisate. Yield 32\%; IR (ATR) v cm $\mathbf{~}^{-1} 3397,3213,1537,1488$, 1350, 1214, 1190, 1006, 959, 835, 761, 702; ${ }^{1} \mathrm{H}$ NMR (500 MHz, CD $\left.30 \mathrm{OD}\right)$ 8 7.61-7.49 (m, 5H, CHAr), $7.25\left(2 \mathrm{~s}, 1 \mathrm{H}, \mathrm{CH}_{\mathrm{Ar}}\right), 5.19-5.09\left(\mathrm{~m}, 2 \mathrm{H}, \mathrm{CH}_{2} \mathrm{O}\right), 4.54\left(\mathrm{~s}, 2 \mathrm{H}, \mathrm{CH}_{2} \mathrm{Ph}\right), 4.06\left(2 \mathrm{~s}, 3 \mathrm{H}, \mathrm{NCH}_{3}\right), 3.72-3.63$ $\left(\mathrm{m}, 4 \mathrm{H}, \mathrm{N}\left(\mathrm{CH}_{2} \mathrm{CH}_{2} \mathrm{Cl}\right)_{2}\right), 3.51-3.33\left(\mathrm{~m}, 8 \mathrm{H}, \mathrm{N}\left(\mathrm{CH}_{2} \mathrm{CH}_{2} \mathrm{Cl}\right)_{2}, \mathrm{C}_{2} \mathrm{~N}^{+} \mathrm{CH}_{2} \mathrm{CH}_{3}\right), 3.06-2.96(\mathrm{~m}, 2 \mathrm{H}$, $\mathrm{CH}_{2} \mathrm{NHP}$ ), $2.97\left(\mathrm{~s}, 3 \mathrm{H}, \mathrm{N}^{+} \mathrm{CH}_{3}\right), 2.13-1.93\left(\mathrm{~m}, 2 \mathrm{H}, \mathrm{CH}_{2} \mathrm{CH}_{2} \mathrm{CH}_{2}\right), 1.45\left(\mathrm{t}, 3 \mathrm{H},{ }^{3} \mathrm{~J}_{\mathrm{H}-\mathrm{H}}=7.3 \mathrm{~Hz}, \mathrm{~N}^{+} \mathrm{CH}_{2} \mathrm{C}_{3}\right)$; ${ }^{13} \mathrm{C}$ NMR (126 MHz, CD $\left.\mathrm{OD}\right) \delta 147.69\left(\mathrm{C}_{\mathrm{ArNO}} \mathrm{N}_{2}\right), 134.85\left(\mathrm{~d},{ }^{3} \mathrm{~J}_{\mathrm{C}-\mathrm{p}}=7.3 \mathrm{~Hz}, \underline{\mathrm{C}}_{\mathrm{Ar}} \mathrm{CH}_{2} \mathrm{O}\right), 134.16$ $\left(\underline{\mathrm{C}} \underline{\mathrm{Ar}}_{\mathrm{C}} \mathrm{CH}_{2} \mathrm{~N}\right), 131.94,130.43,129.28,128.64\left(6 \mathrm{C}, \mathrm{CH}_{\mathrm{Ar}}\right), 66.67\left(\underline{\mathrm{C}} \mathrm{H}_{2} \mathrm{Ph}\right), 59.69\left(\mathrm{CH}_{2} \underline{\mathrm{C}} \mathrm{H}_{2} \mathrm{~N}^{+}\right), 57.84(\mathrm{~d}$,

$\left.{ }^{2} \mathrm{~J}_{\mathrm{C}-\mathrm{p}}=4.6 \mathrm{~Hz}, \mathrm{OCH}_{2}\right), 50.05\left(\mathrm{~d}, 2 \mathrm{C},{ }^{2} \mathrm{~J}_{\mathrm{C}-\mathrm{P}}=4.7 \mathrm{~Hz}, \mathrm{~N}\left(\mathrm{CH}_{2} \mathrm{CH}_{2} \mathrm{Cl}\right)_{2}\right), 47.99\left(\mathrm{~N}^{+} \mathrm{CH}_{3}\right), 43.17(2 \mathrm{C}$, $\left.\mathrm{N}\left(\mathrm{CH}_{2} \mathrm{CH}_{2} \mathrm{Cl}\right)_{2}\right), 38.87\left(\mathrm{CH}_{2} \mathrm{NHP}\right), 35.21\left(\mathrm{NCH}_{3}\right), 25.68\left(\mathrm{~d},{ }^{3} \mathrm{C}-\mathrm{p}=4.6 \mathrm{~Hz}, \mathrm{CH}_{2} \mathrm{CH}_{2} \mathrm{CH}_{2}\right), 8.46$ $\left(\mathrm{N}^{+} \mathrm{CH}_{2} \underline{\mathrm{CH}}_{3}\right)$; ${ }^{31} \mathrm{P}$ NMR (202 MHz, CD $\left.{ }_{3} \mathrm{OD}\right) \delta 18.10,18.09$; HRMS (ESI) m/z $549.1893[\mathrm{M}]^{+}$ (calculated for $\left[\mathrm{C}_{22} \mathrm{H}_{36} \mathrm{Cl}_{2} \mathrm{~N}_{6} \mathrm{O}_{4} \mathrm{P}\right]^{+}$549.1907).

4.1.4.27.

3-(\{[bis(2-chloroethyl)amino][(1-methyl-2-nitro-1H-imidazol-5yl)methoxy]phosphoryl\}amino)-N-methyl-N-piperidinylpropane-1-aminium iodide (32)

Alkylation of amine 27 (37 mg, $76.2 \mu \mathrm{mol}$ ) with methyl iodide ( 6 eq. initially followed by 6 eq after $20 \mathrm{~h}$ ) using the standard procedure (reaction time: $24 \mathrm{~h}$ ) afforded compound 32 analytically pure, as a yellow hygroscopic solid (47 mg, $75.0 \mu \mathrm{mol}$ ). Yield 99\%; IR (ATR) v cm $\mathbf{~ c m}^{-1}$ 3420, 3213, 1652, 1537, 1489, 1349, 1217, 1190, 1007, 980, 959, 835, 744; $\left.{ }^{1} \mathbf{H} \mathbf{~ N M R ~ ( 5 0 0 ~ M H z , ~ C D C l ~}\right) \delta 7.28(\mathrm{~s}, 1 \mathrm{H}$, $\left.\mathrm{CH}_{\mathrm{Ar}}\right), 5.20\left(\mathrm{dd}, 1 \mathrm{H},{ }^{2} \jmath_{\mathrm{H}-\mathrm{H}}=13.4 \mathrm{~Hz},{ }^{3} \mathrm{~J}_{\mathrm{H}-\mathrm{P}}=8.3 \mathrm{~Hz}, \mathrm{CH}^{\prime} \mathrm{O}\right), 5.16\left(\mathrm{dd}, 1 \mathrm{H},{ }^{2} \mathrm{~J}_{\mathrm{H}-\mathrm{H}}=13.5 \mathrm{~Hz},{ }^{3} J_{\mathrm{H}-\mathrm{P}}=8.7 \mathrm{~Hz}\right.$, $\left.\mathrm{CH}^{\prime \prime} \mathrm{O}\right), 4.09\left(\mathrm{~s}, 3 \mathrm{H}, \mathrm{NCH}_{3}\right), 3.74-3.64\left(\mathrm{~m}, 4 \mathrm{H}, \mathrm{N}\left(\mathrm{CH}_{2} \mathrm{C}_{2} \mathrm{Cl}\right)_{2}\right), 3.54-3.36\left(\mathrm{~m}, 10 \mathrm{H}, \mathrm{N}\left(\mathrm{C}_{2} \mathrm{CH}_{2} \mathrm{Cl}\right)_{2}\right.$, $\left.\mathrm{C}_{2} \mathrm{~N}^{+}\left(\mathrm{C}_{2} \mathrm{CH}_{2}\right)_{2} \mathrm{CH}_{2}\right), 3.09\left(\mathrm{~s}, 3 \mathrm{H}, \mathrm{N}^{+} \mathrm{CH}_{3}\right), 3.02\left(\mathrm{td}, 2 \mathrm{H},{ }^{3} \mathrm{~J}_{\mathrm{H}-\mathrm{P}}=12.2 \mathrm{~Hz},{ }^{3} \mathrm{~J}_{\mathrm{H}-\mathrm{H}}=6.2 \mathrm{~Hz}, \underline{\mathrm{H}}_{2} \mathrm{NHP}\right), 2.04-$ $1.87\left(\mathrm{~m}, 6 \mathrm{H}, \mathrm{C}_{2} \mathrm{CH}_{2} \mathrm{~N}^{+}\left(\mathrm{CH}_{2} \mathrm{C}_{2}\right)_{2} \mathrm{CH}_{2}\right), 1.76-1.65\left(\mathrm{~m}, 2 \mathrm{H}, \mathrm{N}^{+}\left(\mathrm{CH}_{2} \mathrm{CH}_{2}\right)_{2} \mathrm{C}_{2}\right) ;{ }^{13} \mathrm{C}$ NMR (126 MHz, $\left.\mathrm{CDCl}_{3}\right) \delta 146.67\left(\mathrm{C}_{\mathrm{ArNO}}\right), 134.94\left(\mathrm{~d},{ }^{3} \mathrm{~J}_{\mathrm{C}-\mathrm{P}}=7.0 \mathrm{~Hz}, \underline{\mathrm{C}}_{\mathrm{Ar}} \mathrm{CH}_{2}\right), 129.33\left(\mathrm{CH}_{\mathrm{Ar}}\right), 62.51$ (3C, $\left.\underline{\mathrm{CH}}_{2} \mathrm{~N}^{+}\left(\underline{\mathrm{CH}}_{2} \mathrm{CH}_{2}\right)_{2} \mathrm{CH}_{2}\right), 57.96\left(\mathrm{~d},{ }^{2} \mathrm{~J}_{\mathrm{C}-\mathrm{P}}=4.9 \mathrm{~Hz}, \mathrm{OCH}_{2}\right), 50.11\left(\mathrm{~d}, 2 \mathrm{C},{ }^{2} \mathrm{~J}_{\mathrm{C}-\mathrm{P}}=4.7 \mathrm{~Hz}, \mathrm{~N}\left(\underline{\mathrm{CH}}_{2} \mathrm{CH}_{2} \mathrm{Cl}\right)_{2}\right)$, $43.23\left(2 \mathrm{C}, \mathrm{N}\left(\mathrm{CH}_{2} \underline{\mathrm{C}} \mathrm{H}_{2} \mathrm{Cl}\right)_{2}\right), 38.90\left(\mathrm{CH}_{2} \mathrm{NHP}\right), 35.34\left(\mathrm{NCH}_{3}\right), 25.20\left(\mathrm{CH}_{2} \mathrm{CH}_{2} \mathrm{NHP}\right), 22.01,21.02$ (3C, 
$\left.\mathrm{N}^{+}\left(\mathrm{CH}_{2} \underline{\mathrm{CH}}_{2}\right){ }_{2} \mathrm{CH}_{2}\right) ;{ }^{31} \mathrm{P}$ NMR (202 MHz, CD 30 OD) $\delta$ 18.03; HRMS (ESI) m/z 499.1752 [M] ${ }^{+}$(calculated for $\left.\left[\mathrm{C}_{18} \mathrm{H}_{34} \mathrm{Cl}_{2} \mathrm{~N}_{6} \mathrm{O}_{4} \mathrm{P}\right]^{+} 499.1751\right)$.

\subsection{Biology}

\subsubsection{Surface plasmon resonance (SPR) binding assay}

SPR assay was carried out on a Biacore T200 instrument (GE Healthcare) with a CM4 sensor chip (GE Healthcare). First flow cell was left empty for background signal substraction and second flow cell was used for immobilization of aggrecan from bovine articular cartilage (Sigma-Aldrich). To immobilize aggrecan, the sensor chip was first activated using a 1:1 mixture of 0.2 M 1-ethyl-3(3-dimethylaminopropyl)carbodiimide hydrochloride and $0.5 \mathrm{M} \mathrm{N}$-hydroxysuccinimide (amine coupling kit, GE Healthcare) at a flow rate of $5 \mu \mathrm{L} / \mathrm{min}$ for 10 min. Aggrecan was then coated on the sensor chip at $400 \mathrm{\mu g} / \mathrm{mL}$ in running buffer HBS- $\mathrm{P}^{+} 1 \mathrm{X}(0.01 \mathrm{M} \mathrm{HEPES}, 0.15 \mathrm{M} \mathrm{NaCl}, 0.05 \% \mathrm{v} / \mathrm{v}$ surfactant p20, pH 7.4) with $6 \mathrm{mM}$ hexadecyltrimethylammoniumbromide (CTAB) at $5 \mu \mathrm{L} / \mathrm{min}$ to a level of $\sim 500$ response units (RU). Unoccupied binding sites were blocked using $1 \mathrm{M}$ ethanolamine ( $\mathrm{pH} 8.5$ ) (Amine coupling kit, GE Healthcare) at $5 \mu \mathrm{L} / \mathrm{min}$ for $10 \mathrm{~min}$. The studied molecules (analytes) were diluted in running buffer HBS- $\mathrm{P}^{+} 1 \mathrm{X}$ before application to the sensor chip at $30 \mu \mathrm{L} / \mathrm{min}$ with 600 seconds association time and 200 seconds dissociation time. Regeneration of the sensor chips was achieved using $2 \mathrm{M}$ aqueous $\mathrm{NaCl}$ solution for 150 seconds. A primary screen of different compounds was performed by binding level analysis at $500 \mu \mathrm{M}$. The SPR responses were obtained by subtracting the responses measured in the aggrecan immobilized flow cell with the response measured on the negative control flow cell (without immobilized aggrecan) for potential non-specific binding and $1 \mathrm{mM}$. Dissociation constants $\left(K_{D}\right)$ were determined for a shortlist of compounds after injection of height different concentrations of analytes $(0.2,0.4,0.5,0.6,0.8,1,1.5,2 \mathrm{mM})$ and using BioEvaluation software with a "steadystate affinity analysis". 


\subsubsection{In vitro anti-proliferation assay}

Human HEMC-SS chondrosarcoma cell line was obtained from the European Collection of Authenticated Cell Cultures and cultured in DMEM/F12 medium (Life Technologies) supplemented with $10 \%$ fetal calf serum (Dutscher) and $4 \mu \mathrm{g} / \mathrm{mL}$ gentamicin.

After trypsinization, HEMC-SS cells were seeded in 96-well plates at a density of $20.10^{3}$ cells in $150 \mu \mathrm{L}$ of the corresponding culture medium and allowed to adhere overnight. Increasing concentrations of drugs or evofosfamide (TH-302, Abmol) diluted in DMSO (maintaining final DMSO concentration at $0.5 \%(\mathrm{v} / \mathrm{v}))$ were added. After plate incubation for $24 \mathrm{~h}$ in normoxic $(21 \%$ $\left.\mathrm{O}_{2}, 5 \% \mathrm{CO}_{2}, 37^{\circ} \mathrm{C}\right)$ or hypoxic $\left(\mathrm{N}_{2}, \mathrm{O}_{2}<0.3 \%, 37^{\circ} \mathrm{C}\right)$ conditions, the culture media were removed and cell layers were washed with PBS. Cells were then left to grow for $48 \mathrm{~h}$ in normoxic conditions. Viability of cells cultured was quantified by AlamarBlue assay. Cytotoxic activity was expressed as the drug concentration that inhibited cell growth by $50 \%\left(I C_{50}\right)$. Experiments were performed at least in triplicates. Data are presented as means \pm SD. Statistical significance was determined using Student's a t-Test. Results were considered significant at $p<0.001$.

4.3. Stability measurements in aqueous buffer. Prodrug $31 \mathrm{f}$ was dissolved in sodium phosphate buffer $\left(10 \mathrm{mM}, \mathrm{pH} 7.4,37^{\circ} \mathrm{C}\right)$ containing $0.13 \%$ DMSO at a concentration of $17 \mu \mathrm{M}$ and incubated at $37^{\circ} \mathrm{C}$. Aliquots were withdrawn at various time points over a $24 \mathrm{~h}$ period and directly subjected to RP-HPLC analysis. The HPLC chromatogram peak area at $322 \mathrm{~nm}$ was used to calculate the concentration of the remaining prodrug. Analytical RP-HPLC measurements were performed on a HP1100 (Agilent, Palo Alto, CA, USA). The separation was carried out on a $\mathrm{C}_{18}$ column (Phenomenex, Luna $\mathrm{C} 18,3.0 \times 150 \mathrm{~mm}, 3 \mu \mathrm{m}$ ) using the following conditions: $\mathrm{C}_{18}$ guard column from Phenomenex (Le Pecq, France) total experiment time: $20 \mathrm{~min}$, flow rate $=0.4 \mathrm{~mL} / \mathrm{min}$, eluent mixture: $\mathrm{H}_{2} \mathrm{O} / \mathrm{ACN}(\mathrm{v}: \mathrm{v})$ containing trifluoro acetic acid (15 mM), gradient: 80/20 at 0 min $\rightarrow 75 / 25$ at $3 \mathrm{~min}$, then $75 / 25 \rightarrow 60 / 40$ for $2 \mathrm{~min}$, then $60 / 40 \rightarrow 50 / 50$ for $5 \mathrm{~min}$, then 50/50 $\rightarrow$ $80 / 20$ for $1 \mathrm{~min}$, then $80 / 20$ for $9 \mathrm{~min}$.

4.4. ${ }^{31} \mathrm{P}$ NMR Kinetics of chemical activation. The prodrug $31 \mathrm{f}(\approx 10 \mathrm{mg})$ was dissolved in $\mathrm{CH}_{3} \mathrm{CN}$ $(90 \mu \mathrm{L})$ and cacodylate buffer $(300 \mu \mathrm{L}, 0.1 \mathrm{M}, \mathrm{pH} 7.4)$, and sodium dithionite was dissolved in cacodylate buffer. $30 \mu \mathrm{L}$ of the solution containing 3 eq. of sodium dithionite were added to the 
prodrug solution, and the reaction mixture was transferred to a $5 \mathrm{~mm} \mathrm{NMR}$ tube, and the data acquisition was started. Spectra were taken at different time intervals over a $24 \mathrm{~h}$ period, and time points for each spectrum were assigned from the initiation of the reaction. Chemical shifts were reported relative to a $\mathrm{Ph}_{3} \mathrm{PO}$ solution (5 \% in DMSO- $d_{6}$ ) as a coaxial reference (26 ppm). The temperature of the probe was maintained at $37^{\circ} \mathrm{C}$ using the Bruker variable temperature unit. The disappearance of the starting material as well as the appearance of the phosphoramidate anion and their relative concentrations were determined by measuring peak areas.

4.5. Stability measurements in plasma. Rabbit blood was collected in heparin anticoagulant. The blood was centrifuged at $4^{\circ} \mathrm{C}$ (1300 g for $10 \mathrm{~min}$ ) to collect the plasma. The prodrug $31 \mathrm{f}(\approx 10 \mathrm{mg})$ was dissolved in $\mathrm{CH}_{3} \mathrm{CN}(90 \mu \mathrm{L})$ and plasma $(330 \mu \mathrm{L})$, the mixture was transferred to a $5 \mathrm{~mm}$ NMR tube, and the data acquisition was started as previously described for kinetics of chemical activation.

4.6. Nitroreductase assay. Recombinant $E$. coli nitroreductase and dihydronicotinamide adenine dinucleotide (NADPH, reduced form, tetrasodium salt) were purchased from Sigma-Aldrich. 10 $\mu \mathrm{L}$ of a prodrug stock solution $(1.7 \mathrm{mM})$ in ultra pure water with $13 \%$ DMSO were added to

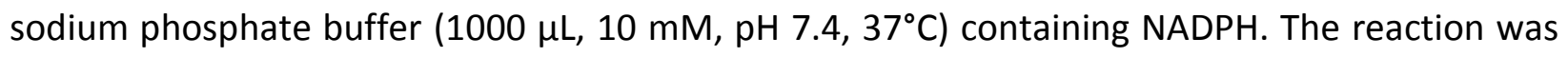
initiated by addition of $E$. coli nitroreductase ( 25 or $15 \mu \mathrm{L}, 1.0 \mathrm{mg} / \mathrm{mL}$ in sodium phosphate buffer; final concentrations: prodrug: $17 \mu \mathrm{M}$; NADPH: $0.9 \mathrm{mM}$; nitroreductase: 25 or $15 \mu \mathrm{g} / \mathrm{mL}$ ). Aliquots were withdrawn at various time points over a $2 \mathrm{~h}$ period and the reactions were followed by RPHPLC as a function of time. The separation was carried out in the same conditions as previously described for phosphate buffer stability. The HPLC chromatogram peak area at $322 \mathrm{~nm}$ was used to calculate the concentration of the remaining prodrug. Between the time points, all solutions were incubated at $37^{\circ} \mathrm{C}$. Reference solutions containing $10 \mu \mathrm{L}$ of compound stock solution and $100 \mu \mathrm{L}$ NADPH solution (9 mM) completed with phosphate buffer solution (1000 $\mu \mathrm{L}$ final volume), were prepared and analyzed under the same conditions in order to distinguish between nitroreductase-based activation and enzyme-free reaction. 


\section{Acknowledgements:}

The authors would like to thank Fernand Leal for his technical support on IR measurement, and Emna Benzarti for his technical support on NMR in Tunisia.

Funding : This work was supported by the Ligue contre le cancer (2017-2018, projet reference

R16146CC / RAB16025CCA) and PRT-K, Translational Cancer Research: INCa-DGOS, D-TECT (project reference R15066CC / RPT15003CCA)

Available Supporting Information: Synthesis and characterization data of compounds 9-27 and ICF05016. ${ }^{1} \mathrm{H}$ NMR, ${ }^{13} \mathrm{C}$ NMR and ${ }^{31} \mathrm{P}$ NMR Spectroscopic Data for all synthesized compounds 132. 


\section{References}

(1) Bone Sarcomas: ESMO Clinical Practice Guidelines for Diagnosis, Treatment and Follow-Up. Ann. Oncol. 2014, 25 (suppl_3), iii113-iii123.

(2) Gelderblom, H.; Hogendoorn, P. C. W.; Dijkstra, S. D.; Rijswijk, C. S. van; Krol, A. D.; Taminiau, A. H. M.; Bovée, J. V. M. G. The Clinical Approach Towards Chondrosarcoma. The Oncologist 2008, 13 (3), 320-329.

(3) Leddy, L. R.; Holmes, R. E. Chondrosarcoma of Bone. Cancer Treat. Res. 2014, 162, 117-130.

(4) Bindiganavile, S.; Han, I.; Yun, J. Y.; Kim, H.-S. Long-Term Outcome of Chondrosarcoma: A Single Institutional Experience. Cancer Res. Treat. 2015, 47 (4), 897-903.

(5) Kim, M.-J.; Cho, K.-J.; Ayala, A. G.; Ro, J. Y. Chondrosarcoma: With Updates on Molecular Genetics. Sarcoma 2011, 2011, e405437.

(6) Donati, D.; Ghoneimy, A. E.; Bertoni, F.; Di Bella, C.; Mercuri, M. Surgical Treatment and Outcome of Conventional Pelvic Chondrosarcoma. J. Bone Joint Surg. Br. 2005, 87-B (11), 1527-1530.

(7) van Maldegem, A. M.; Gelderblom, H.; Palmerini, E.; Dijkstra, S. D.; Gambarotti, M.; Ruggieri, P.; Nout, R. A.; van de Sande, M. A. J.; Ferrari, C.; Ferrari, S.; et al. Outcome of Advanced, Unresectable Conventional Central Chondrosarcoma. Cancer 2014, 120 (20), 3159-3164.

(8) Provenzano, S.; Hindi, N.; Morosi, C.; Ghilardi, M.; Collini, P.; Casali, P. G.; Stacchiotti, S. Response of Conventional Chondrosarcoma to Gemcitabine Alone: A Case Report. Clin. Sarcoma Res. 2015, $5,9$.

(9) Bovée, J. V. M. G.; Hogendoorn, P. C. W.; Wunder, J. S.; Alman, B. A. Cartilage Tumours and Bone Development: Molecular Pathology and Possible Therapeutic Targets. Nat. Rev. Cancer 2010, 10 (7), 481-488.

(10) David, E.; Blanchard, F.; Heymann, M. F.; De Pinieux, G.; Gouin, F.; Rédini, F.; Heymann, D. The Bone Niche of Chondrosarcoma: A Sanctuary for Drug Resistance, Tumour Growth and Also a Source of New Therapeutic Targets. Sarcoma 2011, 2011, 932451.

(11) Muz, B.; de la Puente, P.; Azab, F.; Azab, A. K. The Role of Hypoxia in Cancer Progression, Angiogenesis, Metastasis, and Resistance to Therapy. Hypoxia 2015, 3, 83-92.

(12) Karakashev, S. V.; Reginato, M. J. Progress toward Overcoming Hypoxia-Induced Resistance to Solid Tumor Therapy. Cancer Manag. Res. 2015, 7, 253-264.

(13) Rohwer, N.; Cramer, T. Hypoxia-Mediated Drug Resistance: Novel Insights on the Functional Interaction of HIFs and Cell Death Pathways. Drug Resist. Updat. 2011, 14 (3), 191-201.

(14) Polychronidou, G.; Karavasilis, V.; Pollack, S. M.; Huang, P. H.; Lee, A.; Jones, R. L. Novel Therapeutic Approaches in Chondrosarcoma. Future Oncol. 2017, 13 (7), 637-648.

(15) Italiano, A.; Le Cesne, A.; Bellera, C.; Piperno-Neumann, S.; Duffaud, F.; Penel, N.; Cassier, P.; Domont, J.; Takebe, N.; Kind, M.; et al. GDC-0449 in Patients with Advanced Chondrosarcomas: A French Sarcoma Group/US and French National Cancer Institute Single-Arm Phase II Collaborative Study. Ann. Oncol. 2013, 24 (11), 2922-2926.

(16) van Maldegem, A. M.; Bovée, J. V.; Gelderblom, H. Comprehensive Analysis of Published Studies Involving Systemic Treatment for Chondrosarcoma of Bone between 2000 and 2013. Clin. Sarcoma Res. 2014, 4, 11.

(17) Ivey, J. W.; Bonakdar, M.; Kanitkar, A.; Davalos, R. V.; Verbridge, S. S. Improving Cancer Therapies by Targeting the Physical and Chemical Hallmarks of the Tumor Microenvironment. Cancer Lett. 2016, 380 (1), 330-339.

(18) Chen, F.; Zhuang, X.; Lin, L.; Yu, P.; Wang, Y.; Shi, Y.; Hu, G.; Sun, Y. New Horizons in Tumor Microenvironment Biology: Challenges and Opportunities. BMC Med. 2015, 13, 45.

(19) Baran, N.; Konopleva, M. Molecular Pathways: Hypoxia-Activated Prodrugs in Cancer Therapy. Clin. Cancer Res. 2017, 23 (10), 2382-2390. 
(20) Phillips, R. M. Targeting the Hypoxic Fraction of Tumours Using Hypoxia-Activated Prodrugs. Cancer Chemother. Pharmacol. 2016, 77 (3), 441-457.

(21) Hunter, F. W.; Wouters, B. G.; Wilson, W. R. Hypoxia-Activated Prodrugs: Paths Forward in the Era of Personalised Medicine. Br. J. Cancer 2016, 114 (10), 1071-1077.

(22) Brown, J. M.; Wilson, W. R. Exploiting Tumour Hypoxia in Cancer Treatment. Nat. Rev. Cancer 2004, 4 (6), 437-447.

(23) Denny, W. A. The Role of Hypoxia-Activated Prodrugs in Cancer Therapy. Lancet Oncol. 2000, 1 (1), 25-29.

(24) Grässel, S.; Aszódi, A. Cartilage: Volume 1: Physiology and Development; Springer, 2016.

(25) Miot-Noirault, E.; David, E.; Vidal, A.; Peyrode, C.; Besse, S.; Dauplat, M.-M.; Heymann, M.-F.; Gouin, F.; Chezal, J.-M.; Heymann, D.; et al. 99mTc-NTP 15-5 Assessment of the Early Therapeutic Response of Chondrosarcoma to Zoledronic Acid in the Swarm Rat Orthotopic Model. EJNMMI Res. 2013, 3, 40.

(26) Miot-Noirault, E.; Gouin, F.; Vidal, A.; Rapp, M.; Maublant, J.; Askienazy, S.; Chezal, J.-M.; Heymann, D.; Redini, F.; Moins, N. First Preclinical Imaging of Primary Cartilage Neoplasm and Its Local Recurrence Using 99mTc-NTP 15-5 Radiotracer. J. Nucl. Med. 2009, 50 (9), 1541-1547.

(27) Peyrode, C.; Weber, V.; Voissière, A.; Maisonial-Besset, A.; Vidal, A.; Auzeloux, P.; Gaumet, V.; Borel, M.; Dauplat, M.-M.; Quintana, M.; et al. Proteoglycans as Target for an Innovative Therapeutic Approach in Chondrosarcoma: Preclinical Proof of Concept. Mol. Cancer Ther. 2016, 15 (11), 2575-2585.

(28) Peyrode, C.; Weber, V.; David, E.; Vidal, A.; Auzeloux, P.; Communal, Y.; Dauplat, M. M.; Besse, S.; Gouin, F.; Heymann, D.; et al. Quaternary Ammonium-Melphalan Conjugate for Anticancer Therapy of Chondrosarcoma: In Vitro and in Vivo Preclinical Studies. Invest. New Drugs 2012, 30 (4), 1782-1790.

(29) Voissiere, A.; Weber, V.; Gerard, Y.; Rédini, F.; Raes, F.; Chezal, J.-M.; Degoul, F.; Peyrode, C.; Miot-Noirault, E.; Voissiere, A.; et al. Proteoglycan-Targeting Applied to Hypoxia-Activated Prodrug Therapy in Chondrosarcoma: First Proof-of-Concept. Oncotarget 2017, 8 (56), 9582495840.

(30) Hu, K.; Qi, Y.; Zhao, J.; Jiang, H.; Chen, X.; Ren, J. Synthesis and Biological Evaluation of Sulforaphane Derivatives as Potential Antitumor Agents. Eur. J. Med. Chem. 2013, 64, 529-539.

(31) Ke, C.; Yang, C.; Mori, T.; Wada, T.; Liu, Y.; Inoue, Y. Catalytic Enantiodifferentiating Photocyclodimerization of 2-Anthracenecarboxylic Acid Mediated by a Non-Sensitizing Chiral Metallosupramolecular Host. Angew. Chem. Int. Ed. 2009, 48 (36), 6675-6677.

(32) Ignasik, M.; Bajda, M.; Guzior, N.; Prinz, M.; Holzgrabe, U.; Malawska, B. Design, Synthesis and Evaluation of Novel 2-(Aminoalkyl)-Isoindoline-1,3-Dione Derivatives as Dual-Binding Site Acetylcholinesterase Inhibitors. Arch. Pharm. (Weinheim) 2012, 345 (7), 509-516.

(33) Tap, W. D.; Papai, Z.; Tine, B. A. V.; Attia, S.; Ganjoo, K. N.; Jones, R. L.; Schuetze, S.; Reed, D.; Chawla, S. P.; Riedel, R. F.; et al. Doxorubicin plus Evofosfamide versus Doxorubicin Alone in Locally Advanced, Unresectable or Metastatic Soft-Tissue Sarcoma (TH CR-406/SARC021): An International, Multicentre, Open-Label, Randomised Phase 3 Trial. Lancet Oncol. 2017, 18 (8), 1089-1103.

(34) Van Cutsem, E.; Lenz, H.-J.; Furuse, J.; Tabernero, J.; Heinemann, V.; loka, T.; Bazin, I.; Ueno, M.; Csõszi, T.; Wasan, H.; et al. MAESTRO: A Randomized, Double-Blind Phase III Study of Evofosfamide (Evo) in Combination with Gemcitabine (Gem) in Previously Untreated Patients (Pts) with Metastatic or Locally Advanced Unresectable Pancreatic Ductal Adenocarcinoma (PDAC). J. Clin. Oncol. 2016, 34 (15_suppl), 4007-4007.

(35) Pourmorteza, M.; Rahman, Z. U.; Young, M. Evofosfamide, a New Horizon in the Treatment of Pancreatic Cancer. Anticancer. Drugs 2016, 27 (8), 723-725. 
(36) Duan, J.-X.; Jiao, H.; Kaizerman, J.; Stanton, T.; Evans, J. W.; Lan, L.; Lorente, G.; Banica, M.; Jung, D.; Wang, J.; et al. Potent and Highly Selective Hypoxia-Activated Achiral Phosphoramidate Mustards as Anticancer Drugs. J. Med. Chem. 2008, 51 (8), 2412-2420.

(37) Cavalleri, B.; Ballotta, R.; Lancini, G. C. Synthesis of 1-Alkyl-2-Nitroimidazole-5-Carboxaldehydes. J. Heterocycl. Chem. 1972, 9 (5), 979-984.

(38) Matteucci, M.; Duan, J.-X.; Jiao, H.; Kaizerman, J.; Ammons, S. Phosphoramidate Alkylator Prodrugs. WO2007002931 (A2), January 4, 2007.

(39) O'Connor, L. J.; Cazares-Körner, C.; Saha, J.; Evans, C. N. G.; Stratford, M. R. L.; Hammond, E. M.; Conway, S. J. Efficient Synthesis of 2-Nitroimidazole Derivatives and the Bioreductive Clinical Candidate Evofosfamide (TH-302). Org. Chem. Front. 2015, 2 (9), 1026-1029.

(40) O'Connor, L. J.; Cazares-Körner, C.; Saha, J.; Evans, C. N. G.; Stratford, M. R. L.; Hammond, E. M.; Conway, S. J. Design, Synthesis and Evaluation of Molecularly Targeted Hypoxia-Activated Prodrugs. Nat. Protoc. 2016, 11 (4), 781-794.

(41) Soai, K.; Ookawa, A. Mixed Solvents Containing Methanol as Useful Reaction Media for Unique Chemoselective Reductions within Lithium Borohydride. J. Org. Chem. 1986, 51 (21), 4000-4005.

(42) Hernick, M.; Flader, C.; Borch, R. F. Design, Synthesis, and Biological Evaluation of Indolequinone Phosphoramidate Prodrugs Targeted to DT-Diaphorase. J. Med. Chem. 2002, 45 (16), 3540-3548.

(43) Borch, R. F.; Canute, G. W. Synthesis and Antitumor Properties of Activated Cyclophosphamide Analogs. J. Med. Chem. 1991, 34 (10), 3044-3052.

(44) Hoang, C. T.; Bouillère, F.; Johannesen, S.; Zulauf, A.; Panel, C.; Pouilhès, A.; Gori, D.; Alezra, V.; Kouklovsky, C. Amino Acid Homologation by the Blaise Reaction: A New Entry into Nitrogen Heterocycles. J. Org. Chem. 2009, 74 (11), 4177-4187.

(45) Perspicace, S.; Banner, D.; Benz, J.; Müller, F.; Schlatter, D.; Huber, W. Fragment-Based Screening Using Surface Plasmon Resonance Technology. J. Biomol. Screen. 2009, 14 (4), 337-349.

(46) Çelik, H.; Hong, S.-H.; Colón-López, D. D.; Han, J.; Kont, Y. S.; Minas, T. Z.; Swift, M.; Paige, M.; Glasgow, E.; Toretsky, J. A.; et al. Identification of Novel Ezrin Inhibitors Targeting Metastatic Osteosarcoma by Screening Open Access Malaria Box. Mol. Cancer Ther. 2015, 14 (11), 24972507.

(47) Liu, M.; Lo, C.-Y.; Wang, G.; Chow, H.-F.; Ngo, J. C.-K.; Wan, D. C.-C.; Poon, L. L.-M.; Shaw, P.-C. Identification of Influenza Polymerase Inhibitors Targeting Polymerase PB2 Cap-Binding Domain through Virtual Screening. Antiviral Res. 2017, 144, 186-195.

(48) Iozzo, R. V.; Schaefer, L. Proteoglycan Form and Function: A Comprehensive Nomenclature of Proteoglycans. Matrix Biol. 2015, 42, 11-55.

(49) Meng, F.; Evans, J. W.; Bhupathi, D.; Banica, M.; Lan, L.; Lorente, G.; Duan, J.-X.; Cai, X.; Mowday, A. M.; Guise, C. P.; et al. Molecular and Cellular Pharmacology of the Hypoxia-Activated Prodrug TH-302. Mol. Cancer Ther. 2012, 11 (3), 740-751.

(50) Flader, C.; Liu, J.; Borch, R. F. Development of Novel Quinone Phosphorodiamidate Prodrugs Targeted to DT-Diaphorase. J. Med. Chem. 2000, 43 (16), 3157-3167.

(51) Shulman-Roskes, E. M.; Noe, D. A.; Gamcsik, M. P.; Marlow, A. L.; Hilton, J.; Hausheer, F. H.; Colvin, O. M.; Ludeman, S. M. The Partitioning of Phosphoramide Mustard and Its Aziridinium Ions among Alkylation and P-N Bond Hydrolysis Reactions. J. Med. Chem. 1998, 41 (4), 515-529.

(52) Pink, R. C.; Spratt, R.; Stirling, C. J. M. 1058. Long-Range Effects in Nuclear Magnetic Resonance. Specific Shielding by Aryl Groups in Some Flexible Systems. J. Chem. Soc. Resumed 1965, 0 (0), 5714-5718. 